\title{
Osteology and Phylogeny of Oviparous Cyprinodont Fishes (Order Cyprinodontiformes)
}

\author{
By \\ RAM PRAKASH SETHI
}

\begin{abstract}
A DISSERTATION PRESENTED TO THE GRADUATE COUNCIL OF THE UNIVERSITY OF FLORIDA

IN PARTIAL FULFILLMENT OF THE REQUIREMENTS FOR THE DEGREE OF DOCTOR OF PHILOSOPHY
\end{abstract}

UNIVERSITY OF FLORIDA

January, 1960 


\section{ACKOYOWLDGMENTS}

It has been a long cherished dream of mine to be able to pursue graduate studies in the United States. For making this dream come true by providing me a Graduate Assistantship, I am extramely grateful to the Biology Department and the Graduate School of the University of Florlda. The assistantship not only helped me Pinancially and acadenically but also enabled me to come in contact with many friendly American students with whom I had the opportunity of exchanging ideas on numerous topies. Although lacking appropriate words to express the debt of gratitude which I owe to Dr. John D. K1lby, present chalrman, and to Dr. Arnold B. Grobman, ex-chalreman of my committee, I wish to thank them both for constant guidance and oncouragement during the course of this study. Dr. Kilby originally suggested this problem to me and always answered my numerous questions most sympathetically whlle Dr. Grobman constantly stimulated me to enlarge its horizons. I also wish to thank the other members of ay committee, Drs. Lewis Berner, Walter Auffenberg, Ernest S. Ford, and Howard K. Wallace for numerous courtesies, continued interest in my work, and valuable encouragement.

Much of the material for this atudy was obtained from various institutions and a number of Individuals have made aveilable specimens or information to me. For such generous help, I an deeply obliged to Drs. Curt Kosswig, Zoologisches Staatsinstitut und Zoologisches Museum, Hamburg, W. Gernanys E. Trewavas, British Museum, London, England; 
J. L. B. Smith and R. A. Jubbs, Rhodes University, Grahanstown, South Africa; J. J. Hoedeman, Zoologisch Museum, Amsterdam, Notherlands; James E. Bohlke, Acadenty of Natural Sciences of Philadelphia; L. P. Schultz, William R. Taylor, G. A. Cooper, Dantel M. Cohen and Ernest A. Lachner, United States National Museum, William Follett, California Acadeny of Sciences; Clark Hubbs, University of Texas; Royal D. Suttkus, Tulane University; Caryl P. Haskins, Carnegle Institution of Washington; Donn E. Rosen, Genetics Laboratory, American Museum of Natural Historys Margaret Storey and George S. Myers, Stanford Universitys Howard E. Evans, Cornell University; and Robert R. Miller, University of Miehigan. I an also obliged to Drs. Carl L. Hubbs, Serippa Institution of Oceanography, and Luis Rene Rivas, Untversity of Mlaml, for sending to we several papers pertinent to my problem. I am grateful to Mr. Herbert R. Axelrod, Publisher, Tropleal Fish Hobbyist, for sending to me many Hodachrome transparencies of cyprinodonts as a special gift. To Drs. Robert R. Miller, Donn B. Rosen, Plerce Brodkorb, and Coleman J. Goin I am especially grateful for answering many questions about my research work and for taking continuous interest in the problems which arose. Thanks are also due to Miss Esther Coogle for help in labeling the figures which are included in this study.

For encouragement, for stimulating discussion, and for numerour courtesies, I am deeply indebted to most of the faculty and the graduate students in the Blology Department at the University of For1da. 
To the Craduate School I am graterul for financial assistance which facilitated uy trip to the Cenetics Laboratory of the American Nuseum of Natural History, to study some of the cleared and stained specimens of Dr. Donn $\mathrm{E}$. Rosen and to discuss with him many problems of common interest. This assistance also enabled me to visit the United States National Museum, where I examined materiel and arranged for loans.

To Dr. Ollve I. Reddick, Exacutive Secretary of the United States Educational Foundation in India, and to the Institute of International Bducation, Washington, I am indebted for a Fulbright Travel Crant without which my coming to the University of Florida would have been delayed considerably. I am also thankful to the Covermment of Uttar Pradesh, India, for a amall loan for my studies abroad and to the managing committee of Agra College, Agra, India, for sanctioning a leave of absence. 
Taxonomic Background ................

Materlals and Methods ............... 21

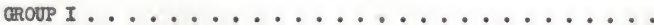

Composition, Range, and Habitat ...........

Composition, Range, and Habitat .......... 73

Osteology ................... . . 73

Summary of Significant Osteological Characters of Group II

Composition, Range, and Habitat ...........

Sumary of Signifleant Osteological Characters

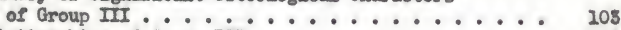
Relationships of Group III ........... 105 Bvolutionary Trends within Group III . . . . . . 109 Relationships of Empetrichthys .......... 118 
TABLE OF CONTENTS--Continued

Couposition, Range, and Hab1tat.......... 116

Osteology .............................. 116

Sumary of Signifleant Osteological Characters

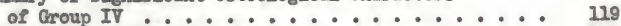

Relationsh1ps of Group IV . . . . . . . . . . 120

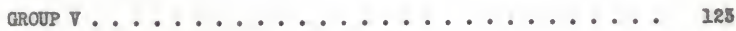

Composition, Range, and Habitat .......... 123

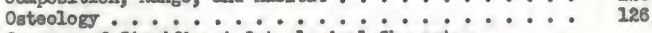

Summary of Signiflcant Osteological Characters

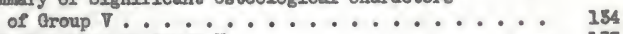

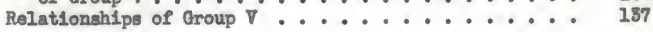

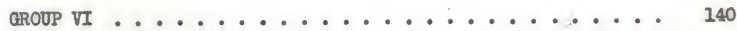

Composition and Range ................. 140

Osteologs

Sumary of Significant Osteological Charactors
of Croup VI . . . . . . . . . . . . . 1. 144

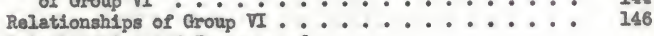

Relationahips and Taxonony of

Lamprichthys tanganicanus .......... 151

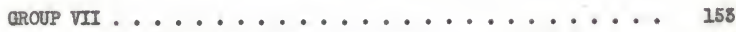

Compostition and Range .............. 158

Osteology . . . . . . . . . . . . 153

Sumary of Significant Osteological Characters

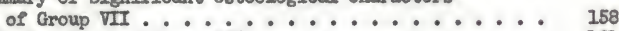

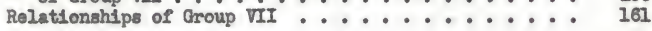

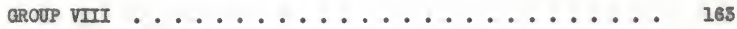

Composition and Range ................ 165

Osteology . . . . . . . . . . . 165

Sumary of Significant Osteological Characters of

Group VIII ................ 166

Relationsh1ps of Group VIII .................. 168 
TABLE OF CONTENTS--Continued

Page

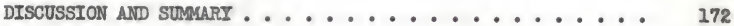

Major Ostaological Characteriatics of

Oviparous Cyprinodonts ............ 173

Osteologleal Features Peculiar to

Different Groups ............. 174

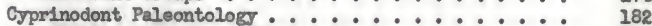

Ancestral Cyprinodont Stoek ........... 187

Evolutionary Trends ................ 191

Taxonomle Implleations . . . . . . . . . . 195

Dendrogram Showing the Relationship of

Cyprinodont Flshes (tentative errangement) . 196

Symopsis of the Families of Ovlparous

Cyprinodonts ................... 204

CONCLUSIONS AND RECONMENDATIONS .............. 207

BXPLANATION OF ABBREVLATIONS USED IN FIQURES ....... 218

FIQURES .................................. 224

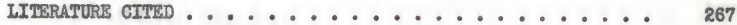

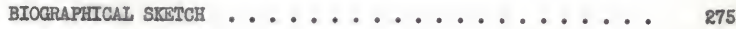




\section{LIST OF TABLES}

Table

Page

1. Vertebral Counts for Seven Species of Group I

Cyprinodonts ..................

2. Dorsal Fin Ray Counts in Five Speeses of Group I

Cyprinodonts ..................

8. Anal Fin Ray Counts for Five Specles of Group I Cyprinodonts .................

4. Pelvie Fin Ray Counts for Pive Specles of Group I Cyprinodonts ..................

5. Pectoral Fin Ray Counts for FIve Species of Group I Cyprinodonts.................

6. Comparison of New World Genera (Group I) and OId World Genera (Group II) of Cyprinodonts . . . . .

7. Comparison of Tooth Structure and Arrangement of Jav Teeth in Several Species of Aroup III Cyprinodonts .................

8. Number of Branchinstagal Rays in Selected Spectes of Group III ............... 100

9. Osteologlcal Differences Between Empetrlchthys and Orestias ................. 
ITST OF FIGURES

F1gure

Page

1. Cyprinodon ₹. variegatus: head akeleton

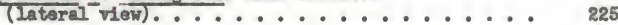

2. Cualac tossellatus: $\mathrm{A}$, hoad skeleton (lateral view);

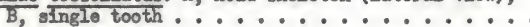

5. Gyprinodon I. variegatus, skull: A, dorsal views

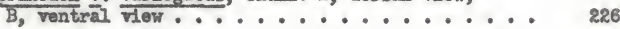

4. Cyprinodon v. variegatus, skul1: A, posterlor view,

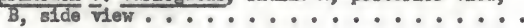

227

5. Occipltal region and I1rgt three vertebrae:

A, Cyprinodon v. varlegatus; B, Cualae tossellatus 228

6. Cyprinodon $\nabla$. variegatus: $A$, ethmoid region (dorsal view)

B, ethmoId reglon (Inner vlew); C, ethmoid region

(slde view), D, vomer and portion of paresphenoid

(ventral view); $F$, nasal (dorsal view) ......

7. Cyprinodon v. varlegatus, orbitotemporal reglon:

A, frontal and postorbital (dorgal view);

$B$, frontal and postorbital (ventral view),

C, lachrymal; $\mathrm{D}$, llsphenoid ..........

250

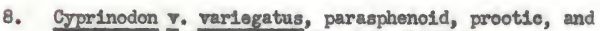
vomer: A, inner view; $B$, ventral vlew ......

9. Gyorinodon $\nabla$. varlegatus, ot1c region:

A, pterotic; B, epiotic; C, sphenotic;

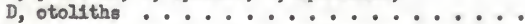

10. Gyprinodon ₹. variegatus, exoceipital and basioccipital:

$A$, venträ view; $B$, Inner view .........

11. Cyprinodon $\mathbf{~}$. varlegatus: A, exoccipital and basioccipitaI (posterior view) $B$, supraocelpital

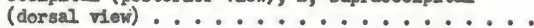

12. Cyprinodon $\mathbf{v}$ variegatus: hyomandibular, symplectic, mandibuzar. arch, and opercular bones (outer vlew) . 


\section{LIST OF FICURES--Cont1nued}

Flgures

15. Cyor1nodon I. varlegatus: hyomandibular, cymplect1c, mandibular arch and opercular bones (meslal v1ew)

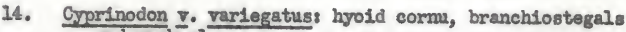
and urohỹal ..................

15. A, branchlal arches of Cyprinodon v. variegatus;

B, pharyngobrenchlal of Iloridichthrs c. carplo ...

16. Cyprinodon v. varlegatus, pharymgobranchtals:

A, inner views B, ventral view ...........

17. Cyprinodon V. varlegatus: A, precaudal vertebrae;

$B$, caudar vertebraes $C$, caudal vertabras and

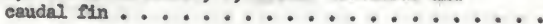

18. Cyprinodon v. varlegatus, IIrst vertebra:

$\mathrm{A}$, anterior Vlew; $\mathrm{B}$, posterlor view ....... 258

19. Cyprinodon $\mathbf{v}$ varlegatus: dorsal $\mathrm{IIn} \mathrm{.......} 238$

20. Cyprinodon $\mathbf{~ v . ~ v a r i e g a t u s : ~ a n a l ~ f i n ~ . . . . . . . . . ~} 259$

21. Gyprinodon I. variegatus: pelvic bones and fin rays . - 239

22. Cyprinodon $\mathbf{v}$. variegatus: $\mathbf{A}$, posttemporal and aupra-

cleithrun; B, pectoral girdle and $\mathrm{fIn}$ rays.....

23. Pectoral girdle and $\mathrm{fin}$ rays of four species of

cyprinodont Plshes: A, Jordenella florldae;

$B$, Garmanella pulchre; C, Mloridiahthrs c.

earpios D, Cualac tesseliatus ..........

24. Aphantus cypr1s: A, skull (doral viow);

B, pectoral glrdle ................

25. A, hyomandibular, syrapleetle, mandibuzar arch and opereular bones of Aphantus orpris; $B$, single tooth; C, hyomandibular, syraplectIc, mandibular areh and opercular bones of Kosswiglehthys ascuamatus . .

26. Kosswiglchthrs asquamatus: A, flrst vertebra; 


\section{ITST OF FIGURES-Continued}

F1gure

27. Fundulus chrysotus: head skeleton (lateral vlew) . . 245

28. Adinia xenica: head skeleton ........... 245

29. Leptolucanla ammata: head skeleton (lateral VIew) . . 246

30. Lucanla parva head skeleton (Lateral view) . . . 246

51. Dundulus chrysotusi skall (dorsal Vlev) ....... 247

92. Fundulus chrysotus: skull (vontral view) ....... 247

35. Fundulus chrysotus, skull: A, lateral vlew; B, posterior vlew ............... 248

54. Luoania parva, skull: $A$, dorgel views B, ventral view ................

85. A, mandibular areh of Fundulus chrysotus, B, basioccipital and exoccipital of Pundulus chrysotus; vomer of Crentehthys balleyl .........

56. Profundulus hildebrandi: $\mathrm{A}$, portion of pectoral glrdle; B, premaxdIa; C, lower jar ......... 250

57. Adinta xenloa: premadilla and dentary ........ 250

38. Enpetrichthys latos: premadila and dentary ..... 251

39. Premaxille and dentary: A, Chriopeops goodel:

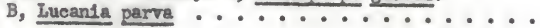

40. Leptolucania ommata: A, hyomandibular, symplectic, and mandibutar arch; $\mathrm{B}$, pectoral girdles $\mathrm{C}$, premadila

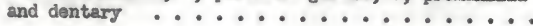

41. Crenichthys baileyi; A, premadila; B, dentary;

42. Fundulus chrysotus: pectoral girdle ........ 254

48. Pectoral girdle: A, Crentchthys baslevi; Adinia xentea; Lucanta parva, and Chrlopeops goode1 ... 


\section{LIST OF FIGURES--Continued}

Figure

Page

44. Fundulus chrysotus: A, IIrst four vertobrae;

B, first vertebra (anterlor view) ........

45. Rivulus bondi: skull (dorsal VIew) . . . . . . 256

46. R1vulus bond1: akull (ventral view) ........ 256

47. Rivulus bondi: A, hyomandibular, symplect1e, mandibular arch and opercular bones:

$B$, hyomandibular, symplectic and some bones

of the mandibular arch; $\mathrm{C}$, preopercle .......

48. Rivulus bondi: A, pectoral girdle; B, portion of branchial skeleton; C, premadila and lower jaw ..

49. Aphyosemion caeruleun, skull: A, ventral view;

50. Aphyosemion caeruleum: A, hyonandibular, symplectic, mandibular arch and opercular bones; $B$, madila..

51. Aphyosemion caeruleum: A, pharyngobranchials; $B$, pectoral glrdles $C$, premaxdile and lower jaw .

52. Orestlas agassiz11, skull: A, dorsel view;

53. Orest1as agassizii: $A$, maxilla; $B$, premadila;

54. Aploche1lichthys katangae: A, skull (dorsal view);

$B$, skul (ventral view); $C$, hyomandibular,

symplect1c, mandibular arch and opercular bones..

55. Aplochell1chthys katangas: A, pectoral girdle;

$B$, pelvic bones and $I$ In rays ..........

56. A, lower pharyngeals of Oryzlas; B, pectoral

girdle of Oryzias; $C$, pelvic bone and fln rays of Oryzies; D, pectoral girdle of Aplochellus ..

57. Cynolebias white1: A, hyomandibular, synalectic, mandibular arch and preopercle; $B$, pectoral girdle; C, portion of the skull ......... 


\section{IIST OF FIGURES-Continued}

Figures

Page

58. Aploche1lus panchwx: trifld median hypural ..... 266

59. Orysias latipes: bifld nedian hypural ........ 268 


\section{INTRODUCTION}

The fishes of the order Cyprinodontiformes, primarily distributed throughout the troplcal regions of the world and represented by more than five hundred species, provide, through a varlety of adaptations to many diverse modes of IIfe, a wealth of material for evolutionary and phylogenetic investigation. As a consequence, these fishes have received much attention, especially in matters of texonomic significance, but practically none of these efforts have been directed toward developing a knowledge of their osteology despite the recognised value of this resource in provlding dependable indieations of phyletic relationships.

The order is usually divided into two suborders, the Amblyopsoidea and the Poecllioldea, the former containing a few, mostly blind, eave fishes of the central and eastern United States, and the latter including all the other cyprinodonts. Further, the suborder Poecilioldea is subdivided into two superfamilles, one containing the viviparous and the other containing the oflparous forms. In the Viviparous superfamily, the structural modifications of the male gonopodium have served to delineate successfully the evolutionary lines of descent but in the orlparous superfamily no such handy taxonomic device is available. This lack of a ready means of analysls not only may be responsible for much of the current uncertainty and controversy relative to the establishment of subordinal taxa 
for the ovlparous representatives but also surely leaves this group without means for analytical comparison with the viviparous members of the order.

The present study was difected to the discovery of osteologleal information on cyprinodonts through examination and analysis of the skeletal characteristics of selected representatives of the oviparous species. It was anticipated that such a study would both reveal and substantiate major phylogenetic relationships and evolutionary trends peculiar to these IIshes, and that it also would provide an osteological foundation for a future, and similar, treatment of the viviparous forms. The completion of such studies should provide for the oviparous and the Viviparous groups a sufflciency of shared characteristics to permit analysis of their interrelationships. The necessity for such an evaluation is indicated by the recognized posaibllity that viviparity may have evolved independently in cyrpinodonts on more than one occasion and that, until this question is resolved, the division of the order into oviparous and viviparous superfamilies must remain a tentative arrangement of convenience.

As a result of the basic needs evident in the eyprinodonts, this study has been restricted to osteological considerations but this Iimitation in no way lessens the necessity for other anatomical, embryological, ecological, physlological, genetic, behavioral, and moogeographic studies which will be necessary to the solutions of varlous problems of relationships and evoluition within this extremely interesting group of ILahes. 
Properly evaluated osteological characters are known to provide dependable evidence of phyletic relationshlps among the vertebrates and, consequently, the osteology of the several vertebrate groups has been exploited for thls purpose. In the case of the Plshes, Regan (1909) presented extensive osteological evidence in support of his clasaification of the teleosts and thereby established a pattern which has been the basis of all subsequent major classifications of the Plahes. Despite the widespread recognition of Ite inportance, the osteology of many Plsh groups has recaived only superfleial attention and mach study remains to be done before our knowledge of the relationships of these groups will be complete. In this connection, the following remarks of Jordan and Bvermam (1896: 623) are st1ll pertinent: "While our knowledge of the osteology and enbryology of most of the families of fishes is very incomplete, It is evident that the relationohips of the groups cannot be shown in and linear serles, or by any concelvable arrangement of orders and suborders. The Ifving teleost flshes have spring from many lines of descent, their relationships are extremely diverse, and their differences are of every possible degree of value. The ordinexy schemes have magnified the Importance of a few common characters, at the same time neglecting other differences of equal Importance. No system of arrangement which throws these fluhes into large groups ean ever be definite or permanent." 
Taxonomic Background

The osteology of the cyprinodonts has not been studied in sufflelent detall to permit a satiafactory analysis. As a result, the taxonomic history of the cyprinodonts has culminated in a system of classiflcation which, although useful, is considered unsatisfactory and inconclusive by most current authorities. The root of the diffculty is vested in the consistent selection of characteristics having questionable value in the appralsal of higher categories. A review of the efforts and the thinking along these 1 ines w1Il be informative by specifying the characteristics employed and by pointing out the difficulties and contradictions which they engender.

In the past the group has been confused Mrst with the cyprinids and later with the Haploml because of superflcial rather than genet1c resemblance. However; it soon became clear that the cyprinodonts have no close affinity with the cyprinids but their relationship with the Haplomi was not questioned unt1l 1908 when Regan raised the issue.

Prior to Regan's contribution, much emphasis was placed on highly variable nutritional and external characteristics. Using such characters, G111 (1872) grouped together the Esocidae, Umbridae and Cyprinodontidae under Cyprinodontoidea which is equivalent to the Cyprinodontidae of Cunther (1880) and subsequent authors. Jordan and Evermarn(1896) grouped Umbridae (Umbra), Iucidae (Esox), Poec1l11dae, and Amblyopsidae under Haplomt whtle Boulenger (1904) included Esoeidae, Dallildae, Cyprinodontidae, Amblyopsidae and ten other familles of Plshes 
In the group Haplomi. Regan (1909, 1911), however, restricted Haplomi. to Include Esocldae, Umbridae and Dallildee, removed the other ten fandlles to dffferent orders, and proposed the ordinal name Microcyprini to Include Cyprinodontidae and Amblyopsidae.

At the same time Regan (1911) proposed a clasalfleation of the Microcyprint and Ilated the ostelogleal characters for the group. He pointed out that, whereas the Haploni showed relationship to the most generalized 1sospondylous Ilshes (Clupea, Herengus, etc.), the Microcyprint were more closely related to the acanthopterygians (spinyrayed flahes). Hubbs (1924) pointed out that the cyprinodonts approach the acanthopteryglans in several Iundamental characteristics.

The classification of the order Cyprinodontiformea is canpllcated and has undergone repeated changes. Many of the changes were due to the recurrent and peraistent attempts of authors to make use of such highly adaptive and mutrition related characters as the longth of the Intestine and the shape and arrangement of the teeth. Such characters are now known to have been repeatedly and independently altered in the different lines of evolution within the group. Cunther (1880) employed nutritional characters when he subdivlded the Cyprinodont1dae into two groups, Cyprinodontidae carnivorae and the Cyprinodontidae 1imnophagae. Similarly Carman (1895) in his momumental work on the cyprinodonts made use of tooth differences for the primary division of the group. Although such characters were later found to be misleading at this level of classifleation, they may be employed suceessfully to separate terminal elements formed by 
one or a few geners. In addition, these adaptive characters at times may be used for grouping genera into larger natural eategorles proVided they are employed in combination with comparatively conservative characters which provide more rellable indication of reletionahip. The elassifleation of the order Cyprinodontiformes as proposed by Regan (1911) has been considerably amended and elaborated upon by several workers, but primarily the revisionary work has been done by Hubbs (1924, 1926, 1936 and 1950) and Hyers (1925, 1927, 1928a, 1928b, 1931, 1932, 1933, 1935a, 1935b, 1936, 1958 and 1942). The papers dealing with these contributions are scattered in varlous fournals and several of them are not readily avallable. For this reason, an outline of the classification currentiy in use is presented here for reference purposes:

Order: CyprinodontLformes (Cyprinodontes Agassiz, Mlerocyprini Regan, Cyprinodontida) ${ }^{1}$

Suborder: Amblyopsoldea

Family: Amblyopsidae

Genera: Chologaster Agassiz

Amblyopsis Dekay

Typhlichthys Girard

'Suborder: Poec1lioidea

Fanfly: Cyprinodontidae

IOrdinal name as recomnended by the comittee on flsh classiflcation, pp. 326-327 of Copela, 1950 and by Balley, 1952. 
Subfandly: Fundulinae

Tribe: Fundulins

Genera: Profundulus Hubbs

Empetrichthys Gilbert

Crentehthys Hubbs

Fundulus Lacepede

Adinta Girard

Iucania Girard

Leptolucania Myers

Chrlopeops Fowler

Cubenichthys Hubbs

Oxyzygonectes Fowler

Chriopeoides Fovler

Valencia Myers

Tribe: Aplocheilini (Rivilini) ${ }^{2}$

Genera: Aplochellus MeClelland

Epiplatys G111

Aphyosemion Myers

Nothobranchius Peters

Pachypanchax Myers

Rubbsichthys Sehultz

2Yyyers (1938) In a footnote on p. 137, polnted out that the tribe RIvilini (1951) should be callod Aplocheilini, and that Aplochellini should be known as Oryziatini. 
Tribe: Aplocheilini (Rivulint)--Continued

Genera: RIvulus Poey

Cynolobias Steindachnor

Rachovia Myers

Pterolebias Garman

Rivulichthys Myers

Neofundulus Myers

Trigonectes Myers

Austrofundulus Hyers

Iribe: Aplocheilichthyint

Cenera: Procatopus Boulenger

Eypsopanchax Myers

Platypanchax Ahl

Aplocheillchthys Bleeker

Meropanchax Myers

Cynopanchax Anl

Plataploche1lus Ahl

Tribe: Oryziatini

Cenus: Oryzias Jordan and Snyder

Subfamdily: Lamprichthylnae

Genus: Lamprichthys Regan

Subfandly: Orestiatinae

Cenus: Orestias Cuvier and Valenelennes 
SubPandly: Cyprinodontinae

$$
\begin{aligned}
& \text { Genera: Cyprinodon Lacepede } \\
& \text { Moridichthys Hubbs } \\
& \text { JordaneIla Coode and Bean } \\
& \text { GarmaneIla Hubbs } \\
& \text { Cualac Miller } \\
& \text { Anatolichthys Kosswlg and Sozer } \\
& \text { Kossw1g1chthys Sozer } \\
& \text { Aphanius Nardo } \\
& \text { Aphaniopg Hoedenan }
\end{aligned}
$$

Fandly: Goodeldae

Subfandily: Ataeniobinae

Cemas: Ateeniobiug Fubbs and Turner Subfantly: GoodeInae

$$
\begin{aligned}
& \text { Cenera: Alophorus Hubbs and Tumer } \\
& \text { Zenotoca Hubbs and Turner } \\
& \text { Chapalichthys Neek } \\
& \text { Goodea Jordan } \\
& \text { Zoogoneticus Meek } \\
& \text { Allodont1chthys Fubbs and Tumer } \\
& \text { Neophorous Hubbs and Turner } \\
& \text { Xenophorus Hubbs and Turner } \\
& \text { Allotoca Hubbs and Turnar }
\end{aligned}
$$

Subfamlily: Characodontinae

Cemus: Characodon Gunther 


\section{Subfamily: Girardinichthyinae \\ Ceners: IIyodon E1gemmann \\ Balgadichthys Hubbs \\ Girariniehthys Bleeker \\ Lermichthrs Hubbs \\ S1kifria Meok \\ OLlentodon Hubbs and Turner \\ Neotoca Hubbs and Turner}

Family: Jenymsildae

Gemus: Jenynsia Cunther

Fanily: Poec17ildae

$$
\begin{aligned}
& \text { Subfantly: Gambuslinae } \\
& \text { Tribe: Gambusilnt } \\
& \text { Cenera: Heterophallus Regan } \\
& \text { Gambusia Poey } \\
& \text { Belonesox Iner }
\end{aligned}
$$


Tribe: Hetarandrilni--Continued

Genera: Allogambusia Hubbs

Alloheterandrla Hubbs

Neoheterandria Henn

Pseudopoectlla Regan

Tribe: Quintanini

Genusi Quintana Hubbs

Tribe: Girardinini

Genera: Girardinus Poey

Toxus EIgemmann

Clarldichthys Garmann

Allodontium Howell-Rivero and RIvas

Dactylophallus Howell-RIvero and RIvas

Tribe: Cnesterodontini

Genera: Cnesterodon Garman

Darlentchtys Habbs

DIphracantha Henn

Phallocerus Eigemmann

Phallotorymus Henn

Subfandly: Poeclliopeinae

Genera: Poec111stes Hubbs

Poeclliopsis Regan

Anlophallus Hubbs

Phall1chthys Hubbs 
Subfandly: Poecillopsinae--Continued

Genera, Carlhubbsia Whitley

Phalloptychus EIgemann

Xenophallus Hubbs

Subfandly: Xenodexdinae

Cenus Xenodexia Hubbs

Subfandly: Poec1l1Inae

Tribes Poecillins

Cenera: Poec1lia Bloch and Schnelder

Micropoec111a Hubbs

Inia Poey

Parapoec111a Hubbs

Lebistes Flilp1

Allopeocllia Hubbs

Mollienesla LeSueur

Tr1bes Xtphophorint

Cenus: XIphophorus HaekeI

Tribe: Pamphorint

Genera: Pamphorlchthys Regan

Pamphor1a Regan

Subfandly Alfarinae

Genera: Furelpents Hubbs

Alfaro Meek

Subfamily' Tomeurinae

Cenus: Tomeurus E1germann 
Fandly: Adrianichthyidae

\section{Generas Xenopoecillus Regan \\ Adrianichthys M. Weber}

Fandly: Horaichthyldae

Genus: Hora1 Chthys Kulkarn1

It is pertinent here to mention some of the attempts to make the organization of the fanilies of the order Cyprinodontiformes as natural as posadble. Such a consideration will show that classiflcations based on a single character are often untenable, and that this is especially true when the characters involved happen to be adaptive.

Woods and Inger (1957) grouped the IIve recognized specles of amblyopsids into three genera, Chologaster, Amblyopsis and Typhlichthys, and in the process they symonymized Troglichthys Eigenmann with Amblyopsis DeKay from which the former differed mainly in the absence of pelvies. In this connection they (1957: 243) maintained that little significance could be attached to the pelvics because of their extreme varlabllity in Amblyopsis spelaes. Ragan (1913) published a revision of the subfamily Poscilitnae (Poecllitiee of Hubbs and subsequent authors) on the basis of gonopodial structure. Since then the structure and the arrangenent of the terminal elements of the gonopodium of the poecllild flshes have been used widely In the systematic arrangements of the genera and species. Regan's classiflcation of the poecllild flshes has aubsequently undergone 
cons1derable revlsion by thubbs (1924, 1926, 1936), Howell-Rivero and Hubbs (1936), Howell-Rivero and Rivas (1944), Hubbs (1950), Cordon and Rosen (1951), Rosen (1952) and Rosen and Gordon (1953).

The subfamily Tomourinae, whlch contains a single genus Tomeurus from South Amerlea was confused with the Poecllildae but 18 now lnowm to be an oriparous form. Horeover, Tomeurus shows certain strilaing superfleial resemblances to the Indian genus Horafchthys, and Hubbs (1941, 447) in commenting upon the relationships of these two genera concluded that they ". . arose independently from the cyprinodont groups that are respectively characteristic of the two reglons." Both Hubbs and Kyers (Kulkarn1, 1940: 384) have suggested that the subfantly Tomeurinae be raised to a fantly level. Concerning the placement of Tomeurus and Horaichthys in two separate famflles, Hubbs, in a letter written to Hora and published by Kulkarni (1940: 384), remarked: "To do this would emphasize the remarkable example of convergent evolution wh1ch 1s involved." More recently Rosen (1958: 3) also has suggeated that the subfamily Tomeurinae be raised to a fanily level. Kulkarni (1940), therefore, establiahed the new famlly Horaichthyldae to recelve Horaichthys setnal and showed the species to be elosely related to Oryzlas. Both Hubbs and Lyers have expressed agreement with this action (Kulkarni, 1940, 1948; and llubbs, 1941).

The family Coodeldae has been revised by llubbs and Turner (1939). The characters used in the revision relate to the structure of the ovary in adult and half grown ferrales and to attributes of the rectal processes of the embryos. Earlier attempts at the elassifleation 
of this famtly by Jordan and Evermarn (1896), Meek (1904), Regan (1906), Jordan (1925) and Hubbs (1924, 1928) were based on dental and intestinal characteristics. These characters, however, were shown to be untenable by Hubbs and Turner (op. clt.) who also established that not only do the characters related to nutrition show intergradation when a large serles of forms are compared but also, and more signteicantily, the classification so derived does not conform to the evident IInes of phyletic relationship. The new characters, however, have their limitations in that they can be used with certainty onis for adult or nearly adult females. This complicates and hinders the final classification of apecies known only from males. In this connection Hubbs and Turner (ㅇ․ cit.: 23) remariced: "The important point is that these characters are the ones indicating the natural groups, and that classifleations surely should be made natural rather than convenient."

Bach of the two fantlies Jenynsildae and the Anableptdae contain one genus, Jenymsia and Anableps respectively. Hubbs (1924) pointed out that the latter group might have been derived from the former. He (op. c1t.2 4) therefore proposed for each a subfamlly status under a single famlly, Anablepldae. In any case, the two groups might be taken to be closely related. According to Myers (1951) the family Jenynsildae differs from the aberrant Anablepidae in considerably lesser number of vertebrae, less depressed skull, presence of postcle1thera, naked intromittent organ, and normal eyes. 
The family Adrianichthyldee is not well known. Weber and Beufort (1925) reviewed the described specles. These seen to be conflned to the lakes of Celebss and but a fow spectmens have been found. Wvers (1981) pointed out that they differ considerably from the other fandies and may be viviparous.

The Phallostethidae, small Ifshes from the Kalayan region and externally somewhat resembling the cyprinodonts, have been shown by Hyers (1928a) to be not even members of the order Cyprinodontiformes. Berg (1947) placed these Plshes in a separate order Phallostethiformes Indieating them to be related to Cyprinodontifornes but manifesting a further step toward Perclfornes (Acanthopteryg11).

The remaining fandly, Cyprinodontidae, the subject of the present study, is the largest and the most widespread of the order Cyprinodontiformes. The fantly contains more than three hundred species of sindlar flshes which unfortunatoly possess no such ready Index of relationship as that provided by the gonopodium of the Poecilildae. The older attempts at generlc segregation were based mainly on a few external differences which collapse completely as characters when large serles of species are contpared.

Regan (I911) indicated some rundamental differences between Aplochellus and Panehax which were elaborated upon by Sundre Raj (1916). Ahl (1924, 1928) attempted a classlfieation of the Old World genera, placing much reliance on the differences in dentition. Myers (1925, 1927, 1928a, 1928b, 1931, 1952, 1953, 1955a, 1985b, 1986, 1958, 1942, 1952), In almilar attenpt at the classifleation of the 
oviparous cyprinodonts, dsagreed with Ahl (op. oit.) on many points. One of his papers was devoted to a delineation of the primary groups of the ovlparous genera and forms a key to the general clasalfieation of the oviparous cyprinodonts (Lyers, 1951).

The classifleation of the family Cyprinodontidae, however, st1II remains a controveralal 1ssue among 1chthyologlsts. Since 1951, when Myers published a general elassifleation of this group, a number of now forns have been described. The discovery of the two genera Crenichthrs Hubbs and Gualae MIIer have aroused doubts as to the deairability of recognising two separate subfadilies, Cyprinodontinse and Iundurinae, on the basts of differences in teeth alone. The other two subfamilles, Orestiatinse and Lamprichthyinae, contain a single gemus each, and the latter only one species, Lamprlchthys tanganicamis from Lake Tanganylka. The gemus Orestias, however, has speciated into a number of forms in Lake Titicaca in the high Andes in Peru (Tchernavin, 1944).

M11er (1955: 9-10) pointed out that the characters listed by Lyers (1951) as diagnostle of the subfanily Fundull Inae were not applscable in many cases, ๑.g., Profundulus, Austrofundulus and many spectes of Funculus. Therefore he suggested that Myers' (op. c1t.) diagnosis of the subfamily Fundulinee should be modifled in two particulars: (1) there are more than 34 vertebree, for Profundulus has as wany as 59, at least elght specles of Fundulus have as nany as 57, and two species of that gemas S. stellifer (Jordan) and I. seninolis O1rard, have up to 88 (Garman 1895: 105, 108; Clothe1r 1950: 41; M111er 1955: 9-10); and (2) the caudal eIn Is scaled more than half 
way to the tip in some species of profundulus, e.g., P. guatemalensis. This is also true of at least one spec1es of Austrofundulus as pointed out by Kyers (1932: 160, and 1942: 112, $\mathrm{Mg} .13$ ). Further, the teeth of the Fundulinas, although typically conical, may be bicuspid as in Crenichthys. Pherefore, Miller (1955) suggested that the subfandly Cyprinodontinae might be combined in a single subfamily along with the subfandily Tundulinae. In such a case, this single subfamily would be described as having conloal, bleuspld, or tricuspid teeth. Moreover, as further pointed out by Miller (1955, 9), Carlonellus, described from Eeuador by White (1927), has tricuspid teeth, but otherwlse looks 14ke a funduline. Miller (1955) then pointed out that on further study, Carlonellus may prove to bridge the small gap currently used to separate the Cyprinodontinae and the Pundulinae. Agatn, while discussing the relationships of Cualac tessellatus, Miller (1956) discussed the same problem and proposed to unite the two subfandlies into one subfamdly Cyrpinodontinae. In this connection he (1956: 3) surmized that "Cualec may well be as closely related to Fundulus, with conical teeth, as to the Cyprinodontids, with trieuspid teeth," and cautioned that (1956, 8) "To base higher clsssification solely or largely on dental features may be misleading, as it surely was in the diversifled Mexdcan flahes of the family Goodeldae." However, this recognition of one subfanily instead of two was proposed as a tentative arrangement as Miller (1956:9) himself pointed out.

Hoedeman and Bronner (1951) and Hoedeman (1954) have proposed many changes in Myers' (1931) classification. One such change, the 
erection of the tribe Profundulidae (Hoedemen and Bronner, 2951) to Include Profundulus and Adinia, and the Old World genera Velencia and Kosewigichthys, has been debated with vigor by Miller (1955: 10-11) who regarded It to be an unnatural assemblage and suggested Its abandonment. In vlew of the above conslderations it was evident that the classification of the family Cyprinodontidue was in need of a reexamination based upon as many criteria as possible. Since, moreover, our knowledge of the precise relationships of the numerous genera, especially the fossil ones, is inadequate, it was felt that a thorough knowledge of their osteology was essential to a satisfactory attempt at their classiflcation.

In the absence of such comparative structures as the gonopodia of viviparous poecllifids, the relationships of the ovlparous cyprinodonts must be based on other comparative characters. Comparative ostoology, as has already been pointed out, affords a valuable elue to relationships. Such a study, however, has been entirely neglected for the cyprinodonts except for a few linited attempts by Remaswand (1945, 1946) and Kulkarni (1948). Rameswand. (op. eit.), however, dld not have phylogenetic considerations in mind when he selected more or less unrelated genera for comparison. Kulkarni (op. cit.) on the other hand, compared the head skeletons of the three genera of Indian cyprinodonts and reached certain important conclusions when he (op. cit.: 103) observed thats "A comparison of the various skeletal features of the three Indian Cyprinodonts studied reveals greater affinity between 
ㅍ. [oratehthys] gotant and O. [ryzias] melastigna than between A. [plocheilus] Iineatus and O. [yyzlas] melastigma and Pinally substantiates the view held previously by the author that H. [oralehthro] setant must have evolved directly from $\underline{0}$. [yzias] melastigna." Fubbs (1924) pointed out that Profundulus, of all American genera, diverges least from a general ancestral type. More recently, however, Hyers (1958) commented that instead the oriental genus Aplocheflus presents by far the largest number of basic characters that have become specialised or even lost in other members of the fandly. As the present study progressed and other genera allied to Aplocheilus were exanined, it became clear that both of these above viewe were in need of re-evaluation.

The geographical distribution of the order Cyprinodontiformes and eapecially the fanlly Cyprinodont1dae presents problens of Interest to the student of blogeography. The eyprinodonts are chlofly a freshwater group. Therefore, next to the 0starlophys, a wholly Ireshwater group, it ahould yleld data of considerable zoographleal slgnificance. It was thought that these and ainllar problems would be capable of interpretation once the interrelationships of these Plshes were knorm. 


\section{Materials and Mothods}

This study is besed upon specimens some of which were collected locally while others were obtained from various institutions. The abbreviations used in reference to collections follow

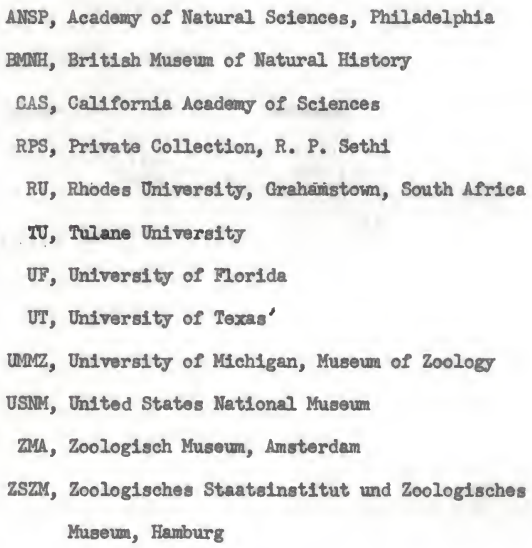

Materials

A list of cleared and stained specimens used in this study is given below:

Cyprinodon variegatus varlegatus

23 Codar Iey, Fla. (RPS)

Cyorinodon macularius

2 Salton Sea, Calte. (UMMZ 133169) 
Cyprinodon salinus

2 Soda Lake, Cal1f. (LAMZ 172291)

Jordanella Ploridae

23 near Cedar Key, Fla. (RPS)

Forldichthys carpio carpio

10 Cedar Key, Fla. (RPS)

Cualac tessellatus

5 Lea Modia Luna, San Luis Potosi, Mexdco (WML 17136)

Garmanella pulchra

5 Cienega, Iueatan, Mexdco (UMMZ 143097)

Fundulus chrysotus

6 near Cedar Key, Fla. (RPS), 6 Gainesville, Ma. (RPS)

Fundulus grandis

5 Cedar Key, Ma. (RPS)

Fundulus similis

4 Cedar Key, Fla. (UF 5203)

Fundulus confluentus

6 Bayport, Ma. (UF 5126)

Fundulus nott1

4 Hawthorne Prairle, Marion County, Fla. (UF uncat.)

Fundulus cingulatus

6 near Baxter, Baker County, Fla. (UF 1825)

Funculus ollvaceus

4 Robbers Cavo State Park, Okla. (UF 7915) 
Fundulus kansae

2 Boonsboro, Missour1 (UNM 170950)

Adinia xeniea

15 Cedar Key, Fla. (RPS)

Wueania parva

18 Cedar Key, Ma. (RPS)

Chriopeops goode1

6 Bayport, Ma. (UT 589)

leptolucania onate

10 Ellis Bay Pond, Baker County, Ma. (UF meat.)

Impetr1chthre latos

2 Iye County, Mevada (MNZ 140490)

Grenichthrs nevadee

2 Nye County, Mevade (WAZ 132175)

Crentehthre baileyl

2 Incoln County, Nevada (UMY 125008)

Profundulue hildebrands

2 Chipas, Mexdico (UNAZ 166691)

Aphanius sypris

I Ak-Gol bel Ergl1, Turkey (ZSzaM uncat.)

Aphanius fagciatus

1 Kucukselanece, Istanbul, Turkery (ZSTM uncat.)

Aphanius chantrel

1 Cihanbeyl1, Turkey (ZSAM uneat.) 
Aphaniops dispar

1 Aquarium Stock (ZSZM uncat.)

Anatolichthys transgrediens

1 Ac1-Col, Turkey (ZSZM uncat.)

Kosswiglehthys asquamatus

1 Hazor-Golu, Turkey (ZSZM uncat.)

Valencia hispanica

I Aquarium Stock (ZSZM uncat.)

Rivulus bondi

5 Caracas, Veneruela (UMMZ 141915)

Cynolebias white1

1 Rio de Janeiro (USMM uneat.)

Austrofundulus stagnalis

4 Lagunillas, Veneruela (OMMZ 141919)

Aphyosemion caervileun

2 Lagos, Britiah Migeria (ZSZM uncat.)

Nothobranchius taeniopygus

I Kafue River, Zambezi River System (RU uncat.)

Aplocheilus panchax

4 Lake Pandjaloe, Java (UMMZ 146561)

Oryias latipes

4 Pond beside Matsu Bay, Japan (UMMZ 146592)

Orestias agassizil

4 R10 Grande de Lipez, BoIivla (CAS 16125) 
Micropanchax loati

1 Nile (BanH 1907.12.2.2709-11)

Aploche1lichthys schoelleri

I N110 (BMNH 1907.12.2.2649-50)

Aplocheilichthys johnstni

2 Chobe RIver, Upper Zambezl River System (RU uncat.) Aplocheillahthys katangae

1 North Rhodesis (RU uncat.)

Lamprichthys tanganicanus

I Lake Tanganica (ZSZM uncat.)

\section{Methods}

Duse to the small size of the fishes included in the present study, it was impossible to prepare dry skeletons by maceration or by any other method. Therefore, the specimens were cleared, steined and placed In glycerine according to the method of Davis and Gore (1936) and Evans (1948). In order to see the details of the osteology, spec1mens were dissected free of tissue under the binocular microseope and, with the ald of a camera lucida, drawings were made at successive stages of dissection.

In order to determine which etructures vary with age or between sexes, serles of specimens were prepared of each sex and of graded sizes from juventles to adults. This was possible only with the local species which were available in sufficiently large numbers; other specles were represented by few specimens. 
Before attempting an analysis of the osteological characters of the various genera of eyprinodonts, it seemed desirable to have a general idea of eyprinodont ostoology. The skeleton of Cyprinodon variegatus variegatus (Lacepede) is therefore, deseribed in detail. This species was selected to serve as a basis of comparison in an analysis of the comparative osteology of the varlous genera because of Its widespread distribution and the abundance of material avatlable for this study.

Two other species of Cyprinodon, ‥ salinus MLllier and C. macularius Baird and OArard, have also been included in the general deseription in order to cover the range of ostoological variation within the genus. Later in the study it was found that the monotypic genera Floridichthys, Jordanella, Garmanella, and Cualac agree suffielently with Cyprinodon in osteological characters to pernit them to be treated as a group in both the descriptive and the analytical phases of the study.

Additional to this group composed of Cyprinodon and 1ts allies, other groups became apparent and have recelved group treatment simflar in approach to that used in the fIrst group. These groups are listed for reierence purposes as followa:

Group I (eyprinodont1ds). Gyprinodon, Florldichthys, Jordanella, Oarmanella, and Cualac.

Group II (aphanids). Aphanius, Aphantops, Anatolfchthys, and Kosswigichthys. 
Group III (Iundulids). Fundulus, Lucanta, Adinta, Chriopeops,

Leptolucania, Empetrichthys, Crenichthys, Profundulus,

Cubanichthys, and Oxyzygonectes.

Group IV (valenc1ds). Valenc1a.

Group V (aploche1l1ds). Aploche1lus, Aphyosemion,

Nothobranchius, Rivulus, Cynolebias, Austrofundulus;

Epipletys, Pachypanchax, Rachovia, Pterolebias,

Trigonectes, Rivulichthys, Neorundurus, and

Hubbsichthrs.

Group VI (aploche1lichthylans). Aploche1lichthys,

Ijpsopanchax, Platypanchax, Proestopus, M1 eropanchax,

Cynopanchax, Plataplocheilus, and Lampmichthys.

Group VII (oryztanes). Oryzias.

Group VIII (Orestians). Orestias. 


\section{GROUP I}

\section{Composition, Range and Habitat}

The geographic range of this group extends from the Colorado River system and the easterm and aouthern United States to the Caribbean coast of South America.

The following genera are included:

Cyprinodon Lacepede. About 13 species.

$$
\begin{aligned}
& \text { Range: eastern, southern and southwestern United States } \\
& \text { to northern South Americe and the West Indes } \\
& \text { (Andros Island, Bahamas; Etang Sawmatre, HaIti } \\
& \text { and Jamajce). }
\end{aligned}
$$

Habitat? mostly in the quiet shallows of fresh, brackish and salt waters, including desert warm springs; not adapted as active swimmers and consequentily seldom found in swift or turbulent waters.

Moridichthys Hubbs. Monotypic.

Range: Florida and Yucatan.

Habitats ehieny marine littoral.

Jordanella Goode and Bean. Monotypic.

Range: ondemic to Florida

Habitat: swamps, ponds and ditches. 
Garmanella Hubbs. Monotyple.

Range: Iucatan Peninsula aouthward to Corozal, British Honduras.

Habitat: bracklsh to nearly freah waters. Cualac Miller. Monotypic

Range: lnown only from wari springs in San Luls Potos1, Mexdco.

\section{Osteolog:}

The following specles of Group I have been studied:

Gyprinodon variegatus varlegatug (Iacepede), C. macularius Baird and Girard, C. salimus Miller, Foridichthye carplo earpio (Gunther), Jordanella Noridae Goode and Bean, Garmanella pulchra Hubbs, and Cualac tessellatus Miller.

The osteology of various genera has been consldered under the following heads: head skeleton, vertebral colvmn, and IIns and Pln-skeleton.

Cyprinodon $\nabla$. variegatus was selected for detajled description and basis of comparison. WIth appropriate modifications the following account will apply not only to all the genera of croup I but also to all other Groups under consideration. Subsequent descriptions, therefore, consist mainly of a delineation of points of difference from the Cyprinodon pattern. 
Head Skeleton (FYgs, 1 and 2)

The head sikeleton 1 s composed of the sloull proper and the Nisceral skeleton which includes the jaws, the hyold, the branchial arches and the bones of the oparculum. Elements of the head akeleton consist of the cartilage bones, the secondarily developed investing bones, and cartilaginous structures which remaln unossified even in the adult.

In adult specimens of Cyprinodon $\mathbf{v}$ variegatus the head 18 amost as long as deep. Its greatest depth 18 near the posterior end and from that point it tapers aharply toward the jaws. It is also broader posteriorly than in either the anterior or the midorbital reglons (M1gs. $8 \mathrm{~A}$ and $5 \mathrm{~B}$ ). The narromess of the interorbital region 1s due to weakly developed aupraorbital processes which are ollghtly rafsed above the general level of the skull and consequently appear to be convex dorsally. The interorbital width in the middle of the orbital region is about half the width of the skull taken between the outer edges of the pterotica. The premaxlllary processes are short and In prepared skeletons, there is a distinct gap between then and the maxdlae,

Skull (F1gs. 3 and 4)

The akull proper consiats of that complex of bones and cart1lages which are situated around the brain and cannot be readsly aeparated from each other. This complex includes all the bony structures developed from the original chondrocranium as well as the secondary bones attached to it including the vomer and the parasphenold. 
The dorsal surface of the skull is almost $h$ at except for the supraorbital processes of the frontals which are mildily convex. The posterolateral corners of the skull, on elther side of the eplotics and the posterlor portions of the frontals, are situated below the general level of the skull and thereby form a depresalon. The supraocc1pital processes are slightly ralsed from the general level of the skull due to the presence of a small supraocclpital crest.

On the ventral alde, the anterior half of the skull 18 occupled by the large orblts which are separated by a narrow parasphenold in between. The portion of the skull represented by the perasphenold appeara to be a IIttle elevated below, while small depresstons occur in the posterolateral comers. Two amall elevations are present, one on elther s1de, around the ares occupled by the large sacculiths. Most of the cartilage bones are separated from each other by thin pleces of cartilage in the interspaces between their margins.

The anterior region of the bratn case 18 poorly provided with bony structures. There is a small ethmold cartilage in front, but both the orbitosphenolds and the basisphenold are absent. The alisphenoids are very small, posteriorly situated, and do not meet in the median IIne.

The skull, for the purpose of more detalled description, may be divided Into four main reglons: the ethnoldal, the orbitotemporal, the otile or auditory, and the ocelpital. Ethmold Region (Fige. 1 and 6)

The ethmold region forms the most anterior portion of the cramium. The ethnold cartilage extenda from under the anterior margins 
of the frontals up to the marillae. Dorsally the entire region is roofed over by the nasals and the anterlor margins of the frontils ventrally the mesethnoid, the vomer and the tip of the parasphenold form the Roor; and Iaterally the lateral ethmolds provlde the sides. Ethmold cart1lage (FIg, 6A). The ethmoid cart1lage is a median bar-11ke structure which forms the anterlor margin of the brain case and It has the mesethmold lodged in 1 ts floor. The vomer Iies ventral to the mesethmoid and extends anteriorly for a considerable distance to come in contact with the maxdilae.

Mesethmo1d (F1gs. 6A, 6B). The mesethmold 1a a heart-shaped, scale-11ke bone. It 11 es in the anterior concacity of the nedian ethmold cart1lage and is supported from below by the vomer. The broad base of the mesethmold 1 a directed anterlorly while 1 ts confeal portion points backward.

Lateral ethmoid (MIgs. I and 6). The lateral ethnolds are osslfled, paired bones of the preorbital reglon there they lie along the outer sides of the ethmold eartilage. They come in contact with the lachrymals and are covered dorsally by the anterior margins of the rrontals and the posterior margins of the nasals. Bach ethnoid 1. of very 1rregular shape and consists of an elongated anteroposterlorly directed medial part and a more or loss vertieally disposed transverse expanded plate. The anterior region of the medial part has an articulating facet for the ethmopalatine process of the autopalatine while 1 ts posterlor portion has an artioulating aurface for the parasphenold. The vertically disposed expanded plate forms the 
anterior boundary of the orbit and laterally comes in contact with the lachrymal. The olfactory nerve emerges from the foramen advehens in the laterel ethmold to Innervate the olfactory organ.

Nasals (F1gs. 1, 2A and 6F). The nasals are a pair of elongated and sofmewhat triangular bones. They are situated inmediately anterior to the frontals where they pass over the lateral ethmoids and come in contact with the upper portion of the maxdllae. Ventrally, the nesals come in contact with the lateral ethmolds and the palatine heads; dorsal1y, their upper surfaces contain a tubular supraorbital sensory canal. Vomer (Tigs. 6D and 8). The vomer is a flat, T-shaped, membrane bone attached to the ventrel surface of the ethmold region of the skull. It 11es in the median plane and its broad anterior portion extends forward a considerable distance and comes in contact with the upper portion of the maxillae. Its narrow posterior portion extends backward over the floor of the ethmoid region and is inserted in a groove of the parasphenold. The vomer supports the mesetmold on its upper surface and lacks teeth not only in Cyprinodon v. variegatus but also in all other Cyprinodonts examined during this study except for the aploche1lids (Croup V).

Orbitotemporal region (Figs. $3 \mathrm{~A}, \mathrm{SB}$ and 7)

The orbitotemporal region is imperfectiy developed and 1t cannot be divided clearly Into orbital and temporal or sphenoldal regions. The parietals, the basisphenoid and the orbitosphenotds are absent; the alisphenold is amall and confined to a comer between the sphenotic and orbital pontions of the frontal. The brain case in 
this region lacks bony support to 1ts lateral walls. The eye, which occuples the entire lateral orbital space, covers the brain case from the sides. The orbital space is bounded anteriorly by the lachrymal and the lateral othmoid and posteriorly by the alsphenoid, sphenotic and the postorbital. However, the frontals are well developed and compensate for the scanty development of the other bones. They cover the entire orbitotemporal region and extend over the posterior part of the ethmoidal region. The ventral side of this region is supported entirely by the elongated and narrow parasphenold. The orbitotemporal region, although forming a major portion of the skull, has only a small number of bones, Viz., the paired frontals on the dorsal side, the bones of the eircumorbital series and the allsphenolds on the lateral gides, and the parasphenold on the ventral side. Bxcept for the allsphenoids which are replacing bones, all the others are membrane bones.

Frontals (Figs. 3A, 7A, 7B). The frontals cover a considerable part of the skull on the dorsal adde. They are broed, flat and elongated ossifled plates with their median margins overlapping each other. Their posterior parts diverge laterally and a median supraoccipital bone is wedged between them. The anterior marging of the frontals overlap the ethmoid cartilage and portions of the laterel ethmoids. Posteriorly they extend over the supraocelpital and also come in contact with the otic bones laterally.

Owing to corresponding curvatures on its dorsal side and the disposition of the supraorbital channel, the dorsel surface of the frontal appears to be divided into three reglons, the interorbital, 
supracobital, and sphenoidal or temporal. Noreover, distinct triradiate ridge on its ventrel surface (visible from above in cleared and stained specimens) separates these reglons clearly. Both the interorbital and the supracrbital areas are convex dorsally. The sphenoidal area is situated behind the interorbital and the supraorbital areas and in front of the supraoceipital bone and the otic regions. The alisphenoid bounds the sphenoldal region of the frontal anterolaterally. The supraorbital channel is perforated by the lateralis $\mathrm{Albers}$ which plerce the bone in order to inervate 1 t. Parasphenold (FIgs. 3B and 8). The parasphenoid is applied to the skull from the ventral side and forms a narrow floor for the brain case along almost its entire length. Anterlorly it is wedged between the mesethmold above and the vomer below. Its anterior end 1s somewhat obtuse and broadened, and has a small depression into which the narrow posterior end of the vomer is inserted. Posteriorly, the parasphenold extends over the mesial portions of the prootics and finally overlaps almost all of the ventral half of the baslocclpital. At the anterior portion of the prootic, on each side, the parasphenoid sends off a lateral process which joins the lateral commisaure. At about the same level from where the lateral processes are produced a pair of small V-shaped processes arise from the inner aurface of the parasphenoid. These inner processez are short, point upwards and do not extend laterally. A prominent median ridge is present on the ventral surface of the parasphenold in the interorbital region. The parasphenoid is hollow internally. A myodome, or the so-called eye muscle canal (Allis, 1919), is lacking. This lack of a myodome is due 
to the fact that the Inner processes of the parasphenoid are short and do not extend laterally to join either the prootic or the aliaphenold. Alisphenold (FIgs. 5B and 7D). The allsphenolds are situated in the posterior orbital region of the sirull. Each alisphenoid is a amall roughly triangular bone, wedged in between the frontal above and the sphenotic behind. It also comes in contact with the anterolateral extension of the prootic and 1ts anterior portion is lodged in a depression on the inner gide of the frontal.

Circumorbital series (FIgs, $I$ and $7 \mathrm{~A}, \mathrm{~TB}$ and $7 \mathrm{C}$ ). There are only two bones in the circumorbital series, a lachrymal in the preorbital region and a postorbital in the posterior region of the orbit. There are no supra or suborbitals. In place of the former the supraorbitel process of the frontal protects the eye from above.

Lachrymal. The lachrymal is situated in the preorbital region of the skull. It is 100 sely embedded in the tissue between the maxilla in front and the lateral ethmoid behind, and 18 in contact with both of these bones. It is broad and roughly boat-shaped. Its outer surface is channeled for the sensory canal system.

Postorbital. The postorbital forms the posterior boundary of the orbit and is shaped like an elongated scoop. It Iles external to the vertical $1 \mathrm{mmb}$ of the sphenotic and is channeled for the sensory canal system. Its upper end rests in a small notch of the frontal, while 1ts lower end reaches up to the upper portion of the preopercle. Sclerotic bones. There are two broad, cup-shaped sclerotic bones in the sclerotic coat of each eye. These sclerotic elements are located in the anterior and posterlor corners of the eye opposite the 
lachrymal and the postorbital bones respectively. They are stained red with allzarine dye just as are the other boiny elements. This rather unusual occurrence of bony structures in the eye has also been noted by Ramswami (1945) in Gambusla affinis holbrookd and by Kurkamt (1948) in Aplocheilus lineatus.

Otic region ( $\mathrm{Figs} .1,3 \mathrm{~A}, 5 \mathrm{~B}, 8$ and 9)

The otic region 18 composed of four bonest eplotic, prootic, pterotic and sphenot1c. These are situated on either side in the posteroleteral comers of the skull. The opisthotic is absent. A rather prominent unossifled space is present between the eplotic, pterotic, sphenotic and the posterior edges of the frontal through which one of the otoliths, the sagitta, can be seen.

AII of the otic bones are irregularly shaped because they from the walls of an Irregularly shaped otic capsule. Internally, the Inner laminae of these bones are ossifled in such a manner so as to form eanals or tunnel-like passages for the accommodation of the semicireular canals of the membranous labyrinth. Similarly, recesses are developed on the Inner surfaces of the ot1e bones for ampullae and otoliths.

Prootic (Fgs. 3B and 8). The prootic is situated anterior to the basiooccipital and exoccipltal, and mesially to the pterotic, sphenotic and alisphenold. It is nattened towards its outer surface while internally it is provided with two or three seall ridges radiating laterally from 1ts center. The anterolateral ridge is the most prominent of all and comes in contact with the alisphenold and sphenotic. 
The other ridges are smaller and radiate laterally from the base of the larger ridge, enclosing between them a depression on the inner side of this bone. This depression, along with sinflar depressions In the basioceipltal and exoccipltals, provide a recess for the sagitta and the ampullae of the posterior and the anterior semicircular eanals. Another small depression is located more anteriorly and Immediately behind the trigemino-facialis chamber. The prootic invades the lateral conmissure and sends a small process anterodorsally. This process is perforated by the three orfflces for the exit of the lateral line branches. The lateral comnissure is joined by the posterolateral limb of the parasphenold which extends laterally towards 1t. Another small process from the ventral limb of the parasphenold joins the anterodorsal extension of the prootic. The anterior opening of the trigeminofacials chamber 110 s between the small process from the ventral limb of the parasphenold, anterodorsal extension of the prootic, and the ossifled lateral conmissure. The inner limb of the parasphenoid is small and does not extend laterally to join the anterodorsal extension of the prootic. Additional to the three oriflces already described, there are two more openings on the prootic, one just under the origin of the ventral Iimb of the parasphenoid, and the other mesial to the posterior opening of the trigemino-facialis chamber. The first one is the orifice for the arteria carotis interna while the second accommodates the orbital artery. The posterior myodome from which the posterfor rectus muscle of the eye emerges is not evident. Instead, the posterior rectus muscle emerges from a wide recess above the proot1c and the parasphenold. 
Sphenotic (FIgs. 1, 2A and 9C). The sphenotic occupies the anterolateral border of the otic capsule. On its ventral surface there 18 a depression for the anterior condylar head of the hyomandibular. The sphenotic is produced into an elongated limb which runs dowmward in the postorbital region. Externally, the postorbital covers the downwardly projecting limb of the sphenotic. Anteriorly, the sphenotic comes in contact with the allephenold, dorsally with the frontal, posterlorly with the pterotic, and meaially with the prootic. Internaly the sphenotic is excavated into a short tunnel for the anterior semieircular canol. Nlong with the pterotic and the prootie, the sphenotic forms a recess for the ampulla between the anterior and the horlzontal semicircular canel. Posterolaterally the sphenotic is proctuoed into a blade-like expansion which meets a similar anteriorly directed expansion of the pterotic.

Bpiotic (Figs. 1, 2A, 4B and 9B). The eplotic occuples the posterodorsal border of the otic capsule and comes in contact, anterlorly with the frontal and the aupraoceipital, laterally with the pterotic, and posterlorly with the exoccipital. It covers the posterior semicireular canal and, together with the exoccipital, forms a recess for the ampullae of the posterior and horizontal semicircular canals of the membranous labyrinth. Postarolaterally a Iimb of the forked postteaporal is firmly attached to the eplotic.

Pterotic (Figs. 1, 2A, 4B and 9A). The pterotic occuples the posterolateral border of the otic capsule and 11 es at a conspicuously lower level than the adjacent bones. The depression forned by this 
unusual position is filled with muscle flbres. The pterotic forms the lateral margins of the skull and extends both dorsally and ventrelly. Mesially it is in contact with the eplotic, ventrally with the prootic and anterolaterally with the sphenotic. It is tumneled internally for the horizontal semicircular canal and has a prominent, ventrally disposed facet for the articulation of the posterlor head of the hyomandibular.

Otoliths (FIg. 9D). The sagitta (saccullth) is the largest otolith. It 11 es vertically in a recess formed by the prootic, basioccipital and the exocclpital. It is high and roughly cireular. Its mesial border Is slightly convex whlle Its outer surface is slightly concave. Its dorsal rim is shorter then the ventral edge and is provided with four to five indentations. Almost in the middle of Its mesial convex side, a wide and stralght sulcus opens toward the anterior rim. The posterior end of the sulcus is rounded and does not quite reach the posterior $\mathrm{rim}$. Such a sagitta has been termed as the "Mierocyprinid" type by Frost (1926). The fugular foramen 1s located immediately behind the sagitta.

The asteriscus (Iagenalith) is well developed. It is about half the height of the sagitta and lies upright in a recess of the exocolpital.

The lapillus (utriculth) is the smallest otolith. It is approximately bean-shaped and 11 es anterior to the sagitta in a recess of the prootlc. 
Occipital region ( $M_{1 g s}, 1,2 \mathrm{~A}, 4$ and 10)

The occipital region is formed by the union of four replacIng bones, the supraocclpital, basloccipital, and the two exoccipitals situated on the doraal, ventral and lateral sides of the sikull respectively. The foramen magnum is formed collectively by two lateral exoceipitals, a ventral basioccipital and a dorsal supraoccipital. The oceipital region is in contact with the otic region laterally, with the frontals dorsaly and with the parasphenold ventrally. The basisphenold and the parietals are absent.

The occipital region is in intimate union with the firat vertebra and articulates with it by an oceipital condyle borme on the basioccipital and also by two rather poorly defined surfaces on the exoccipitals. This union is strengthened by the neural arches of the flrst vertebra which are separate and do not fuse dorsally into a neural spine. Instead they are applied on elther side to the posterior edges of the supraoccipital and the exoccipitals. In adult specimens the fusion is so complete through secondary ossification around the area of contact that it is almost impossible to separate the IIrst vertebra from the occipital region without damage to the parts. Due to this disposition of the Iirst vertebra there is a considerable gap between it and the second vertebra (FIg. 5). Other modifications of the first vertebra are described later in connection with the account dealing with the vertebral column. Supraocelpital (FIgs. 3A, and 11B). The supraocelpital is unusually large and constitutes a prominent element in the posterior 
region of the skull. Anterioriy it extends beneath the frontela, dorsolaterally it comes in contact with eploties, and ventrolaterally It meets the exocelpttals. The supraoceipital contributes to the formation of the foramen ragnum, and forms a prominent dome-shaped structure over 1t. Being membrene bones, the frontals are applled secondarily to the cranivin and consequently overlap the margins of the supraoceipital on elther side and thereby reduce the exposed aurfaee of the latter conslderably. From 1ts posterodorsal surface, two supraoceipital processes extend posteriorly and alightly upward from the general level of the skull and are thus situsted above the small supraocefpital exest. These processes are in the form of a pair of vertical laminae, separate throughout in young specimens, but in adults they become fused proximally due to additionel ossification. In the anteromedian portion of the supraoccipital, there is a eart1laginous ares which is lightly colored in all stained specimons. The area has a thin sheet of eartilage on its inner side which divides Into a pair of narrow bands. These bands proceed forward on each side to the alisphenosd.

$$
\text { Exocelpitals (Mgs. 4, 10A, } 10 \mathrm{~B} \text { and 1U). The exocoipitals }
$$

are paired bones and are altuated in the posterior ocelpital region. They, rather than the oplsthoties which are absent, take part in the fornation of the otic caprule. Thus each excoeclpital becomes the auto-ocelpttel but the term exocelpitel is retained here for eonvenience (Kulkarni, 1948). The expecipttals form the sides of the foramen magum and are apparated from each other dorselly 
by the dome-ahaped supraoceipital which completes the foranen from above. Each exoccipltal bears a poorly deflined articulating surface around the ventrolateral corner of the foramen magnum. These surfaees can only be seen in young specimens after carefully removing the first vertebra whlch 18 in intimate contact with the oceipltal reglon through its neural arches. In adult specimens, however, the neural arches and the posterlor extremities of the supraoceipital and the excoccipitals are co-osslfied and It is impossible to separate the first vertebra from the sicull without damaging some of the adjacent parts. Laterally the excocipital comes in contact with the pterotic, dorsally with the supraoccipital, and doraolaterally with the eplotic. From the foramen nagnum, the exoccipital extends laterally 2.8 well as ventrally to join the pterotic and the basioccipital respectively. Along with the pterotic and the basloceipltal, the exoccipital encloses a large recess for the ampuzia and two otoliths, the sagitta, and the esteriscus. Being produced in different directions the bone is irregular in shape. Internally each exoccipital sends a vertical support or plate to the inner side of the basiocelpital (FIg. 1OB). Kulkarni (1948: 75) reported a sindlar arrangement in Aploche1lus Iineatus but was doubtrul of its origin.

Two large and one small foramina are situated on the anteroventral aspect of the excocipital and occur together in the same depression. The Jugular foramen (FIg. 5B) Is large and occurs immediately behind the recess for the saglta. The lower limb of the forked posttemporal is attached to the exoccipital. through a amall cup-1ike bone 
just behind the jugular foramen. The hypoglossal foramen is located on the posterolateral aspect of the exocelpital, above the poorly defined articular aurface for the first vertebra.

Bagloccipltal (FIgs. 4A, 10 and IIA). The basiocelpital forms the floor of the foramen magnum. It is an elongated bone, narrow posteriorly and broad at the anterior extremity. Anteriorly it is in contact with the mesial portions of the prootics while laterally It joins the exoccipitals. The posterior extremity of the parasphenoid is applied to Its anterior end. Internally the anterolateral comers of the basiocelpltel are excarated and form a part of the recess for the sagitta. Posteriorly the bone has a large eircular condyle for articuletion with the centrum of the first vertebre (FIg. WI). The ventral, outer surface of the baslocelpital is nat but Internally the two bony plates descending down from the exoccipItals cut the bone into a median portion and two laterel corners. Into the median portion is lodged the posterior part of the medulis oblongata. The plates thus separate the brain case from the auditory capsules and also strengthen the occipital reglon internally. A foramen is present on either side of the basiocelpital at almost on the same level as the jugular foramen on the exoceipital.

Visceral skeleton

The visceral skeleton consists of seven arches which may be divided into three constituent groups: (1) the mandibular arch forraing the suspensorium of the faws, (2) the hyoid arch forning the hyold 
cornu, and (s) the branchial arches. The flrst two arches are more apecialized than the others and are closely associated with the chondrocranifu. The first, or mandibular arch, glves rise to palatoquadrate and mendibular bars which support the upper and Iower Jaws respectively. The second, or hyold arch, gives rise to the hromandibular which provides attachment for both the palatoquadrate and the hyoid arch. The next four arches support the gill filaments and the seventh is reduced to the tooth-bearing inferlor pharynged bones.

Mandibular arch (Flgs, 1, 12 and 13)

The palatoquadrate bar of the mandibular arch shows two independent osalfications, the autopalatine and the quadrate. A thin mesopterygoid is attached to the above two bones from behtind. The metapterygoid is absent. Meckel's eartilage, which forms the lower jaw during the embryonic condition, becomes osalfled into the articular except for a portion of the original cartilage which persists in the adult. The tooth-bearing dentery grows around the distal part of Meckel's cartilage and forns the biting part of the lower jaw. A small angular and the sesamoid articular are also located on the Inner portion of the jaw. The upper jaw is formed of two palrs of dormal bones, the premaxdllae and the maxdllae.

Quadrate (FIgs. 1 and 12). The quadrate is a large bone situated anterior to the mesopterygoid, the symplectic, the opercle, and the interopercle bones. It consists of two portions, a posterlorly directed lower $11 \mathrm{mb}$ and a thin membranous vertical portion. The lower Iimb of the quadrate 11 es over the preopercle, the interopercle and the 
symplectic while the vertical portion of this bone extends upward and joins the autopalatine and the mesopterygoid. The quadrate bears a prominent, pully-like condylar head for articulation with the articular and thus helps to connect the upper and the lower jaws.

Palatine. The palatine, or autopalatine, is the most anterior bone of the palatoquadrate bar. Its lower, membranous part is applied to the vertical portion of the quadrate while the upper, thicker portion extends dorselly to come in contact with the ethmoid and the $\max 111$ a through 1ts two heads, the ethmopalatine and the restropalatine, respectively.

Dentary. The dentaries form the anterior portion of the two rami of the lower jaw and they come in contact with one another anteriorly through a Iigament. They are, however, not fused to form a mandibular (mentomeckelian) symphysis. Together, the dentarles form the ontire tooth bearing part of the lower faw. The posterior part of the dentary is excavated to receive the distal portion of the articular bone.

Articular. The articular forms the ventrolateral margin of the lower jaw. It is dagger-shaped, wth its stem and blade of unequal length. The anteriorly directed blade of this bone, along with Meckele's cartilage, is lodged Into the excavation of each dentary as mentioned previously. The vertically directed portion of the stem is expanded and prominent, while the ventrally directed piece is small. The sesamold articular $110 \mathrm{~s}$ on the Inner side of the articular near the proximal portion of the elongated blade. On its posterior end 
the articular bears a prominent articular facet for the condylar head of the quadrate.

Angular. The angular is a very small and irregular plece of bone attached to the ventral portion of the articular and positioned closed to the articular facet.

Premaxdllae. The premadilae are prominent tooth-bearing bones which, together, form the entire upper jaw. The premaxdllae of the two aldes meet anterlorly in the midline but do not form a Pused symphysis. Each premaxdla consists of a horizontal toothbearing portion bordering the mouth and an edentulous arm which extends backward and downward to terminate in a spine. This arm is slender at the angle of the mouth but flattens posteriorly before finally terwinating in a spine. The spine lies internally to the distal, pointed portion of the maxdila and projects backward beyond the latter. The horisontal tooth-bearing portions of the premarillae are produced Into small, triangular premaxdllary processes which extend backward. The two processes run cloze together without actually touching each other mes1ally and the extrematies of these processes diverge slightly from each other. The entire premaxilla presents the appearance of an "S" with the extremities slightly pulled apart. There Is a close resemblance, in both number and shape, between the teeth of the premaxdllary and the dentary.

Maxillae. The maxdllae are edentulous and being situated behind the upper jaw, they do not take part in Its formation. Bach maxdlla is a straight rod-like bone. Its lower end lies external to 
the terminal spine of the premaxdila and then ascends upward toward the nasal bone. On reaching the nasal each maxdlla sends off a dorsally expanded outer process. Another but slenderer process is mesially gituated and proceeds forward. The nasal bone comes in contact with the dorsally expanded process of the madila, whereas the lachrymal comes in contract wlth the straight rod-like portion of the madila at 1 ts middle. Bach maxilla bears toward its posterior upper surface a facet for the rostropalatine head of the autopalatine and each is also in contact with the lateral extremity of the vomer. Teeth (FIgs. 1, 2, 12 and 15). Both the premexdIla and the dentary bear a single row of moderately stout tricuspid teeth. Bach tooth is provided with two laterally pointed cusps and a blunt median cusp.

Hyold arch (FIgs. 1, 12, 13 and 14)

The second, or hyoid, arch gives rise to the hyonendibular, the symplect1e and the hyold cornu. The hyomandibular provides attachment for the jaws, the hyold cornu and the opercular bones. The palatoquadrate bar is suspended from the skull through the hyomandibular and therefore the suspensorium is hyostylic.

Fyomandibular. The hyomandibular is an elongated, roughly quadrilateral bone, located vertically in the postorbital region of the skull. It has two prominent condylar heads (MIg. 12) at 1ts upper extremity by which it is articulated with the sphenotic and the pterotic bones. These two latter bones have corresponding facets 
for the heads of the hycmandibular toward their lower surfaces. Another articulating head is situated toward the posterlor surface of the hyomandibular through which it provides attachment to the operculum. Below the two condylar heads, two prominent ridges proceed dowmward. These ultimately join and then expand into a wing-like projection. The preoperculum is adnate to the posterior extremity of this ving-like structure. The lower portion of the hyomandibular is flattened into an elongated rod-like structure and ends in a truncated facet. At the lower extremity of the hyomandibular a amall cartilaginous area provides attachment to the truncated upper extremity of the symplectic and a small interhyal (Mg. 12). The foramen for the ramus hycanandibularis nerve is located in the middle of the hyomandibular.

Symplectic. The symplectic is a plough-shaped bone, lying below the hyomandibular. It consists of an upper rod-like portion and a wing-like lower membranous expansion. The anterior apex of the symplectic is Pirmly wedged in a mesial notch of the posteriorly directed lower limb of the quadrate.

Hyold cornu (FIg. 14). The hyold cornu or hyobranchial skeleton, consists of a pair of arches, one member of which is situated on either side of the buccal cavity. Each arch originates from a cartilaginous plece at the lower extremity of the hyomandibular of Its side, and proceeds dowmard and forward to meet the corresponding arch from the other side in the midventral line on the floor of the buccal cavity. Each arch 18 made up of four segments, the Interhyal, 
the epinyal, the ceratokyal and the hopolyyal. The hypohyals of the two sides are very elose together in the median line and, on their upper surfaces, arpport a modian triangular basihyal. The basihyal forms the anterlormost, median part of the hyold cormu and supports the tongus. On their ventral aspects, the two hypohyals come in eloee approxdmation with another median pleee, the urohyal. The hypohyals, the basihyal and the urohyral, although lying elose together, remaln separate and are joined with each other only by muscles and 11ganents. Interhyel (Fig. 1). The interhyal, or stylohyel, forms the dorsal segment of each of the two arches. It is a mall hourglessshaped bone, disposed vertically toward the mestal side of the upper margin of the membranous portion of the preopercle where it is attached to a small cartilaginous element lying below the rod-like extremity of the hyomendibular. It provides attachment to the next plece of the arch, the epthyal, by means of a cartilaginous olement. Goodrich (1958) considered the Interhyal as probably a new formation rather than as an epibranchial with which 1 t has been compered by others. Ipihyal. The epihyal proceeds anteroventrally from the Interhyal to which it is attached by an artieulating facet on 1ts dorsal extremity. It is a triangular piese with its base directed forvard and the apex hanging down from the interhyal. It is in touch with the following segment, the ceratohyal, by way of a cartilaglnous Interapace between them. The dorsal sides of these two bones, however, are devold of any cartilaginous interspace. Dus to a secondary 
thickening of the bones, a ridge is formed along the entire dorsal edges of the epihyal and the ceratohyal. The most posterior branchlostegal ray is attached on the outer side of the epihyal by a flattened articulating surface of the ray.

Ceratohyal. The ceratohyal follows Immediately from the epinyal with which it is connected along its dorsal edge through the ridge mentioned previously. It has a broad base, but its anterior end becomes narrow where 1 it is provided with an inner and slightly raised articulating facet and an outer almost rectangular cavity. The ceratohyal joins the hypohyal of 1ts side through the two facets mentioned above. Three branchlostegals are attached to the ceratohyol toward its outer side.

Hypohyal. The hypohyal is in elose contact with the ceratohyal. The hypohyals of the two sides come very elose together in the median line but their mesial sides do not ruse and the space between the two is fllled by a small cartilaginous area.

\section{Urohyal, Branchlostegals and Opercular Bones}

The urohyal, the branchlostegal rays and the operevilar bones, although not belonging to the hyold cornu, are described here in Now of their close association with the latter.

Urohycl. The urohyal, or basibranchlostegal, is a thin vertically disposed plate situated very close to the posteroventral portions of the hypohyals and in the middle of the angle formed by the meeting of the two arches of the hyoid cormu. The urohyal is 
Is approxdmately trlangular in shape with its apex nesr the angle of the hyold cornu and the remainder of 1 ts body lyling behind. The apex of the urohyal 18 provlded with two short processes from unieh two Iigaments proceed forward to attach to the ventral surfaces of the hypohyals. I third, but analler, process from the apex of the urohyal Is directed upward and comes in contact with the first bastbranchial.

$$
\text { Branchiostegals (FIg. 14). In Cyorinodon V. variegatus, C. }
$$

macularlus and $\underline{\mathrm{C}}$. salinus there are six branchiostegel rays on each of the two arches of the hyold cormu. These six rays are arranged in two groups according to their structure and manner of attachent to the hyold cornu. The firgt group contains two branchiostegals which are comparatively sall and close together but, as a group they are separated by a considerable gap from the four rays of the aecond group. The two rays of the flrat group are attachod in a conspicuous groove on the Imer aspect of the ceratohyal and are more fIrmly attached to the myold arch. These two rays are of a untform rounded shape except toward the posterior extrendt1es where they become pointed.

The Sour branchlostegals of the second group are sabreshaped, the two outermost more so than the others. 011 four rays of the second group are attrahed to the outer side of the hyold arch, the three inner ones on the ceratohyal, and the outer one on the epinyal. The rays of the second group are flattened toward their proxdmal extremitles where they join the hyold arch and become narrower toward their free distal extremities; also they are broadest just behind their points of attechmant to the hyold arch. The outermost ray 
In the broadest and the longest, reaching up to the posterior extremity of the opercle. All the branchlostegal rays are folded below the opercular bones.

The number and the manner of attachment of the branchiostegals shows 11ttle variation. Out of twenty-three specimens of Cyprinodon I. variegatus examined, only one specimen showed a difference and It had three, rather than the usual two branchiostegals in the first group. Foridichthys c. carpio, Jordanella Noridae, Garmanella pulchra and Cualac tessellatus differ from this description in that they have only fIve branchiostegals, because the first group contalns only one ray.

Considerable importance has been attached to the form and the arrangement of brachlostegals in different groups of flahes. Hubbs (1919: 61) pointed out that in the higher groups of the teleosts there is "... a peculiarly constant arrangement of the branchiostegals." Again, whlle commenting upon the relationships of the order Cyprinodiontiformes Hubbs (1924: 7) stated: "FInally a fact perhaps more conelualvely indicative of a more advanced organization, the branchiostegal rays of the Cyprinodontes are of the acanthopteryglan type, whereas those of the Haploms are of a distinctly more generallzed type." The arrangement of the branchiostegals of the cyprinodonts in the present study agrees with the description given by llubbs (1919), and thus justifles for than a place near the Aeanthopteryglt as was pointed out by Hubbs (1919, 1924). 
Opercular bones (FIgs. 1, 12 and 13). The opercle is a proninent bone on the posterolateral side of the skull. Its upper, posterior, and lower edges are rounded while the anterior margin is straight. There is a rounded process on 1 ts anterior upper aurface which extends beyond the articulating facet, the latter being present toward its inner aspect. The outer surface of the opercle is convex whlle 1 ts inner surface is concave. A concave artieulating facet is present on the Inner aspect of the opercle, by which it articulates with a corresponding convexdty on the hyomandibular.

The preopercle 11es immediately anterior to the opercle. Its posterior, vertically disposed arm comes in contact with the anterior margin of the opercle, while its lower limb is directed anteriorly to Iie under the posteriorly directed lower limb of the quadrate. In between the two arms of the preopercle there is a thin membranous bony lamina which 110 s under the lower extrendty of the hyouandibular and the posterior portion of the symplectic. The vertical and the lower arms of the preopercle are channeled for the lateral line sensory canal system. The preoperele overlaps the subopercle and the interopercle bones.

The subopercle lies below the opercle and is the innermost bone of the opercular series. It is somewhat triangular in shape with its base considerably broadened. Its upper spine-11ke apex 11 s beLow the preopercle. A prominent ridge is present on the spine and posterior to it there is a notch for the reception of the narrow lover portion of the opercle. The subopercle is overlapped anteriorly by the interopercle. 
The interopercle is also triangular. Its apex lles under the posteriorly directed limb of the quadrate, 1ts broad base overlaps the subopercle, whlle it is itself overlapped by the preopercle.

Branchlal arches (F1g. 15)

The branchial akeleton consists of five branchial arches which are serially arranged immediately behind the hyold cornu. Of these, the anterlor four bear gills on their ventral surfaces but the flfth one is greatly modified to form the lower pharyngeal bones. Each arch is made up of two lateral halves which untte in the midventral as well as in the middorsal IInes. Normally, each half of the arch is made up of a pharyngobranchial and an epibranchial on the dorsal side, a ceratobranchial on the lateral side, and a small hypobranchtal near the midventral line. In addition to these, a single, median basibranchial is situated in the midventral line with whlch the two hypobranchial of the two sides are jolned.

The branchial arches are variously modified to serve different functions in different reglons of the pharymx. However, the corresponding segments of different arches show sinilar modifications and therefore, the corresponding segments from different arches are treated together in the description which follows.

Pharymgobranchials. The pharyngobranchtals, or dorsal pharyngeal bones, form the dorsal segments of the branchial arches. They are flattened and moderately thickened structures provided with teeth. The pharymgobranchlals of each side are in close contact and meet aimilar bones from the other side in the middorsal Ine. 
There Is a small but definite amount of muscle tissue between the pharyngobranchials of the two gldes and, consequently, the bones are not fused together. These bones are provided with ventrally directed teeth which work against sinilar but dorsally directed teeth on the lower pharymgeals and help in mastication.

The first pharyngobranchial is a small cart1laginous plece attached to the elrst eplbranchial and, unlike the other pharymgobranchtals, it is not provided with teeth. The second pharyngobranchial is in close contact with the third and fourth pharyngobranchlals, which are rused Into a comparatively large plate. The second pharyngobranchtal bears two rows of teeth and the fused plate usually has five rows. These teeth are relativaly uniform in sige except on the fused plate there there is medial area of larger teeth and a tendency for the teeth to become smaller toward the posterolaterel corners of the plate. The arrangement of the teeth on these dorsal pharymgeal bones is such that the larger teeth oeclude the amaller teeth on the lover pharyngeal bone, whlle the smaller ones occlude the larger ones. The teeth on the lower pharyngeals are typlcally compressed with lateral shoulders aurmounted by hooks. The description of the pharymgobranchials as given for Cyprinodon $\mathbf{v}$ variegatus is applicable to Jordanella foridue and, in general, to the other species of Group I which have been examined. However, in Forldichtys c. carpio the ILrst pharyngobranchlal is distinct and is provided with about two rows of teeth (F1g. 15B); In Garmanella pulchra and Cualac tessellatus the frased third and fourth 
pharyngobranchials are thickened and bear about seven rows of teeth. Eplbranchlals. There are four epibranchials, and these are connected with the pharyngobranchials and the ceratobranchlals. The first two epibranchials are rod-shaped. The base of the first one by which It articulates with the ceratobranchial is broad. The third epibranchial is I-shaped with one of Its arms slightly shorter than the other. The fourth epibranchial is the most prominent of all. It is hammer-shaped and has a prominent head by which it articulates with the fused pharyngeal plate. It also has a prominent tuberosity for muscle attachment and It comes in contact with the fourth ceratobranchilal by a pointed end.

\section{Ceratobranchials. There are four ceratobranchials and these} form the greater part of the branchial skeleton. Each ceratobranchial is an elongated and slightly arched structure and dorsolaterally each is joined to an epibranchial at the lateral margin of the pharynx. From this attachment with the epibranchials, the ceratobranchials bend sharply 1nward and converge mesially, ventrally, and anterlorly for some distance before meeting the corresponding hypobranchials. The first three ceratobranchials are alike in having attachment with the three separate hypobranchials. The fourth ceratobranchial is different in that it does not come in contact with the separate hypobranehial because, in all the specles examined In the present study, the separate fourth hypobranchials are absent. Instead, the fourth ceratobranchials are joined directly to the cartilaginous tips of the second basibranchial. In this connection Ramaswami (1945, 38) observed that in 
both embryonic and adult Gambusia affinis holbrookd "The cerato- and hypobranchials of the fourth arch (hep4.) are not demareated, for a dentigerous inferior pharyngeal plate has come in contact with 1t." Similarly Kulkarni (1948) described the fourth ceratobranchial and the hypobranchials as being rused structures in Aplochellus lineatus.

cill-rakers are present on both the anterior and the posterior surfaces of the first four gill arches but the f1fth arch, which 1s reduced to the lower phryngeal bones, has these structures only on 1 ts anterior surface.

Bypobranchials. The hypobranchlels are associated only with the first three ceratobranchlals and are situated on elther side of the median 2ine. Toward their outer surfaces they are in contact with the ceratobranchials by cartilaginous interspaces while mesially they are joined to the basibranchials.

There is no separate hypobranchial segaent in the fourth arch. As mentioned above, Ramaswami (1945) and Kulkarnt (1948) expressed the opinion that the inner end of the fourth ceratobranchial represents a fused structure formed by the union of a hypobranchial with the ceratobranchial. Chapmen (1934) arrived at a similar conclusion in respect to Novmbra, in which this structure also is absent. Basibranchials. There are only two osstfled basibranchials supporting each of the four branchial arches. These correspond to the second and third basibranchials of other Plshes. However, there are two cartilaginous pieces both at front of the 'PIrst' and 'second' basibranchials and these pleces may represent the unoseifled Plrst and fourth basibranchials respectively. 
Fifth arch, or lower pharyngeal bones (FIg. 16). The flfth arch forms the moat posterior element of the branchlal skeleton. Unilke a typical arch, the flrth branchial arch is modifled into two pharyngeal bones which form the floor of the posterlor region of the pharynx. The outer ends of these two bones taper and diverge from each other, but their anterlor ends and mesial surfaces are stralght and 110 close together in the midventral 1ine. Their anterior extremities approach the fourth ceratobranchials and are attached to the cartilaginous piece at the lower end of the second basibranchial. Teeth, similar in structure to those of the upper pharyngeal bones, are arranged in about Mve rows. Cualac and Garmanella differ from Cyprinodon in having about Ilve rows of teeth. In all these forms, however, the teeth project into the throat and ocelude similar teeth on the upper pharymgeals. On the ventral alde of each pharymgeal bone there 1 a a prominent ridge for mascle attachment.

Posttemporal (FIgs, 1 and 22). The pectoral arch on each side is suspended from the skull by way of a forked posttemporal. Each posttemporal is a $\mathrm{Y}$-shaped bone with the two limbs of unequal length formIng the fork attached to a comparatively thick but short stem. The stem is applied to the supracleithrum, the upper and longer 1 imb of the fork 18 applled to the epiotle; while the amaller and lower IImb Is attached by a swall cup-ahaped plece of bone to the excociptital, at a point Immediately posterolateral to the jugular foramen. The extremity of the IInb applied to the eplotic is somewhat nattened and there is a prominent ridge for muscle attachment ruming on the outer and upper portion of the posttemporal. 
Vertebral Column (F1g. 17)

The vertebral column may be divided into two parts, the precaudal, or trmik region, and the caudal region. The vertebrae are amphicoelous and show modiflcations in different parts of the vertebral colum. These modifications are specially pronounced at the anterior end where the vertebrae come in contact with the skull, and at the posterior end where they contribute to the formation of the caudal rin akeleton.

Vertebral counts for thres specles of Cyprinodon and four related genera of Group I are given in Table 1.

TABLE 1

VERTEBRAI COUNTS FOR SEVEN SPBCIES OF GROUP I CIPRMYDONTS

Species

and Number of Specinens

Examined
Number of Vertebrae

\begin{tabular}{lllllll}
\hline 23 & 24 & 25 & 26 & 27 & 28
\end{tabular}

Cyprinodon v. varlegatus (25)

C. salinus (2)

c. macularius (2)

Moridichthys s. carp10 (18)

Jordanella floridae (23)

Garmanella pulchra (5)

Cualac tessellatus (5)

$\begin{array}{lll}7 & 11 & 5\end{array}$

2

2

18

$2 \quad 21$

5

14 
These Iive genera (Cyprinodon, Jordanella, Foridichthys, Garmanella and Cualac) agree in all essentials of their vertebral colmuns except for variation in number of vertebrae. Consequently, a description of the vertebral elements of Cyprinodon will sufflce for all f1ve.

Precaudal or trunk vertebrae (Fig. 17A)

There are 11 or 12 precaudal vertebrae and they differ most markedly from the succeeding caudal vertebras in lacking haemal canals on the ventral surfaces of their centra. The first vertebra shows the greatest modification and has become closely associated with the occipital region of the skull. The second and third vertebrae have broader neural spines for muscle attachment than do the others. The following few ( 4 to 5 ) vertebrae still possess comparatively broad neural spines but these gradually become narrower posterlorly. The remaining trunk vertebrae assume more normal shapes except that in them the transverse processes are prominent and rentrolateraily locatsd. The first vertebra (Mgs. 1, 5 and 18)

The f1rst vertebra is in close contact with the oceipital region of the skull. Its elongated, somewhat flattened, and membranous neural arches are applied to both the excecipitals and the supraoccipital on either side of the foramen magnum. In complete skeletons, there is a distinct gap between the first vertebra and the second vertebra which follows 1t. Because the neural arches of the f1rst vertebre fall to meet above, a true neural spine is lacking. The first 
vertebra also lacks transverse processes, and vertebral $\mathrm{rbs}$. The epipleurals, which in the following vertebrae foin the proximal parts of the ribs, are attached near the base of the neural arches of the Pirst vertebra.

The second and third vertebrae (Fg. 1 and 5).

These vertebrae have very prominent laterally compressed neural splnes whlch provide large surfaces for the attachment of the dorsal musculature. The transverse processes are short, cup-shaped, and intimately foined to the ventrolateral aspects of the neural arches. They are provided with ribs which like the rest of the trunk vertebrae, I1t into the coneavities of the transverse processes through the intervention of cartilaginous tips. Apertures for the exit of nerves are located imediately behind the transverse processes in the neural arches. The remaining trunk vertebrae are much alike. In them the neural spines progressively become narrower, amaller, and more pointed; the transverse processes, although joined to the lateral aspects of the neural arches, become progressively more prominent and ahift gradually to a more ventrolateral position on the centrun; and in one or two trunk vertebrae Imadiately preceding the caudals, the transverse processes point downward.

The caudal vertebrae ( $F$ Igs. $17 \mathrm{~A}, 17 \mathrm{~B}$ and $17 \mathrm{C}$ )

The caudal vertebree are characterized by the presence of haemal canals between the joined haemal arches. Occaslonally the IIrst caudal vertebra has a amall haemal spine, but the following caudels possess elongated haemal spines. However, the neural and haemal spines 
of the caudal vertebrae which contribute to the caudal fin skeleton are more elongated and compressed distally.

These more posterfor caudal vertebrae also possess membranous bony expansions of variable extent on the anterlor extremities of their neural and haemal spines. The urostyle is conteal in shape and has become completely consolidated with the fan-shaped median hypural. The blunt anterfor end of the urostyle can be clearly seen at the base of the median hypural. There are two hypurals. The larger median hypural is fan-shaped and completely consolldated with the urostyle as mentioned above. The smaller hypural is entirely ventral in position and its shape, size, and position varies considerably. In large Individuals there is a thin bony expansion on the anterior surface of the ventral hypural. In some instances the base of the ventral hypural is close to the urostyle while in others there is a considerable space between them. In one specimen of Cyprinodon varlegatus the base of the ventral hypural is fused with the ventral side of the median hypural, toward the anterior end of the latter. There is one epural and it is afmilar in shape to the ventral hypural. These two bones flank the ventral and dorsal surfaces of the median fan-shaped hypural respectively.

Caudal Fin (FIg. 17C)

The caudal fin skeleton consists of the four terminal caudal vertebral segments, their Nattened neural and haemal spines, one epural and two hypurals. 
The neural and haemal aptines of the last caudal vertebra, excluding the urostylar segment, are flattened and extend posteriorly to enter into the ceudal in skeleton. The dorsal hypural is fanshaped and, along with the second hypural below and an epural above it, supports most of the caudal in rays. The fin rays extend anterlorly over the neural and haemal spines of the last four eaudal vertebrae. The number of the caudal IIn rays varies from 27 to $\mathbf{8 1}$. 111 of the caudal IIn rays are blfid at their bases; they are jointed and brenched, except for a few mall anterlor caudal fln rays which are ubranched.

Doral $F$ in (FIg. 19)

The origin of the dorsal fin in these five ganera of cyprinodonts is located voll in advance of the anal $\mathrm{Nn}$. There are thirteen prosimal radials or pteryglophores (interneurals) between the neural opines of the vertebrae. The first proximal radial differs fron the others in that it does not have a fin ray to support, and 1t lacks both the distal as well as the median radials. This proxdingl radial ray correspond to a keel-1ike structure noticed in many Ilshes, such as those described by Phillipe (1942) for Sardinope eaeralea and W1teman (1954) for Carneglella resce. The remaining twelve proxdnal pteryglophores have both distal as well as median pteryglophores assoclated with then and also support In rays or lepidotrichia. The distal pteryglophores lie between the right and the left half of the bifld fin rays. Each distal radial is almost oplit into two by a median flssure. The median pteryglophores are located between the 
upper extremities of the proximal pteryglophores except between the PIrat and second, where the median radial is absent.

Fin ray counts for Cyprinodion V. varlegatus and four other related genera of Group I are given in Table 2.

\section{TABLE 2}

DORSAL IIN RAY COUNTS IN FIVE SPECIES OF GROUP I CYPRINODONTS

Species

and Number of Specimens

Exanined

Nhmber of Dorsal Rays

$\begin{array}{llllllll}12 & 13 & 14 & 15 & 16 & 17 & 18 & 19\end{array}$

Cyprinodon v. variegatus (23) $15 \quad 8$

Foridichthys c. carpio (18) $10 \quad 8$

Jordane1la floridae (18)

Gamanella pulohra (5)

$\begin{array}{llll}8 & 8 & 6 & 1\end{array}$

Gualae tessellatus (4) 18

32

The firgt fin ray of the dorsal fin in Jordanella floridae is spinous and msegmented throughout in contrast to the other four genera where all the fin rays are soft and segmented. In Cyrpinodon I. varlegatus, however, there is a tendency for the first dorsel Pin ray to become thickened and spine-1ike but this ray remalns segmented distally. 


\section{Anal $\mathrm{Fin}(\mathrm{Fg}, 20)$}

The anal fin is construeted on the same general plan as the dorsal fin. The proxdinal radials extend in between the haemal spines and their number is usually one $18 s 8$ than the number of the fin rays. Both median and distal radials are present.

Fin ray counts for Gyprinodon I. varlegatus and other four related genera of Croup I are given in Table 3 .

\section{TABLB 3}

ANAL FIN RAI COUNIS FOR FIVE SPECTES OF GROUP I CIPRINODONIS

\begin{tabular}{|c|c|c|c|c|c|c|}
\hline \multirow{2}{*}{$\begin{array}{c}\text { Species } \\
\text { and Number of Species } \\
\text { Exramined }\end{array}$} & \multicolumn{6}{|c|}{ Number of Anal Rays } \\
\hline & 9 & 10 & 11 & 12 & 13 & 14 \\
\hline Cyprinodion v. varlegatus (20) & & & 10 & 10 & & \\
\hline Flor1dichthys e. carpio (18) & 1 & 17 & & & & \\
\hline Jordanella florldae (18) & & & & 4 & 11 & 8 \\
\hline Carmanella pulchra (5) & & 5 & & & & \\
\hline Cualac tessellatus (4) & & & 1 & 8 & & \\
\hline
\end{tabular}




\section{Pelvio airdle (Fig. 2l)}

The pelvie girdle consists of a right and a left half and $110 \mathrm{~s}$ In the posterior abdominal region where it is ombedded in the ventral abdoninal muscles. Bach half consists of a pelvic bone and seven fin rays which are connected directly to the posterlor base of the pelvie bone. From each of the pelvic bones a horizontal process is given out mesially to overlap each other and thus bring the two bones into an Intimate union. From the posterior innor aspects of each of the pelvic bones long bony process is given out to mu posteriorly along with but dorsal to the 1 In rays.

Fin ray counts for Cyprinodon v. varlegatus and four other related genere of Group I are given in Table 4.

TABLE 4

PELVIC FIN RAI COUNIS FOR FIVE SPECIES OF GROUP I CYPRINODONTS

Species

and Number of Specinens

Extandined
Number of Pelvic Rays

$6 \quad 7 \quad 8$
Cyprinodon v. variegatus (23)

Forld1ehthys o. carpio (18)

Jordanella Noridae (23)

Garmanella pulchra (5)

Cualac tessellatus (5)

$20 \quad 3$

126

25

14 
Pectoral Girdle (Figs. 22 and 25)

The pectoral girdle consists of a right and a left half. The primary portion of each half consists of the cleithrum, the scapula, the coracoid, the radials and the fin rays while the secondary portion consists of the posttemporal and the supracleithrum.

Each half of the pectoral girdle 110 s immediately behind the skull and is located in such a manner so that portions of the cleithrum, the supracleithrun and the posttemporal are covered by the opercle of 1ts side. The pectoral girdle is connected with the skull on either slde by the forked posttemporal. Portions of the cleithrum and the coracold lie below the skull where they meet gimilar bones of the other side in the midventral line and thus form a floor under the branchial skeleton. Prominent muscles originate from the expanded lower portions of the cleithra and are inserted on the posterlor half of the urohyal.

The cleithrum is elongate; 1ts lower portion is suspended under the head, and 1ts uppor portion is produced into a cleithral process of variable extent in the five genera of cyprinodonts under discussion. In Cyprinodon $\mathbf{v}$. varlegatus the cleithral process is much expanded while in Jordanella florldae it 18 comparatively less expanded. In Flor1dichtys carplo and Garmanelle pulchra the ele1thral process is somewhat pointed and forms a hook around the pectoral base. In the former specles the hook is nearer to the pectoral base than It 18 in the latter species. In Cualac tessellatus the cleithral process Is rather amall and 1ittle modifled. Below the eleithral process 1108 
a prominent scale-like bone which may be termed the subcleithral (posteleithral?) bone (F1gs. I and 22). A prominent ridge runs the entire length of the outer surface of the eleithrum. The portion of the cleithrum anterior to this ridge is concave and situated at a lower level than the remainder of the bone. The anterior portion of the cleithrum is covered over by the posterior margin of the opercle bone. The scapula is roughly rectangular, jotns the clesthrum below the cleithral process and contalns a prominent scapular foramen towards its anterior extremity. A space separates the lower end of the cleithrum and the coracoid. In Cyprinodon $\mathbf{v}$ varlegatus and Floridichthys c. carpio there are four distinot radials, or actinosts, near the posterior margins of the coracoid and the scapula. In Jordanella Noridae, Garmanella puichra and Cualac tessellatus, however, only three distinct actinosts are present because the uppermost is fused with the coracoid.

The pectoral fin ray counts in Cyprinodon $\mathbf{~ v ~ v a r i e g a t u s ~ a n d ~}$ and other sour related genera of Croup I are given in Table 5. 
TABIE 5

PECTORAI, FIN RAY COUNTS FOR FIVE SPECIES OF GROUP I CIPRTHODONTS

\begin{tabular}{|c|c|c|c|c|c|c|c|c|c|}
\hline \multirow{2}{*}{$\begin{array}{l}\text { Species } \\
\text { and Number of Specimens } \\
\text { Excamined }\end{array}$} & \multicolumn{9}{|c|}{ Number of Pectoral Rays } \\
\hline & 12 & 18 & 14 & 15 & 16 & 17 & 18. & 19 & 20 \\
\hline Cyprinodon V. variegatus (16) & & 1 & 1 & 5 & 7 & 2 & & & \\
\hline Floridichthrs c. carpio (16) & & & & & & & 6 & 8 & 2 \\
\hline Jordanella floridae (18) & & & 8 & 8 & 2 & & & & \\
\hline Garmanella pulchra (5) & & & & & 2 & 2 & 1 & & \\
\hline Cualac tessellatus (2) & 1 & 1 & & & & & & & \\
\hline
\end{tabular}

Sumnary of Significant 0steological Characters of Group I

Ethmoid Region

(1) Mesethmoid present and composed of double laminae.

(2) Vomer edentulous.

Orbitotemporal Region

(3) Parietals absent.

(4) Inner processes of the parasphenoid present.

(5) Posterlor myodome absent.

(6) Interorbital area of the frontels triangular; supraorbital area small and slightly convex dorsally.

(7) Postorbital broad. 
Occipital Region

(8) Occipital region in intimate union with the first vertebra.

(9) A distinct gap between the flrst and second vertebra. present.

(10) Articulation of the skull with the first vertebra chiefly by the basioceipital condyle of the former and the neural arches of the latter.

(11) Exoccipital condyles absent.

(12) Both the supraoccipital and the exoccipitals contributing to the formation of the foramen magnum.

(13) Supraoccipital extending backward to form a dome-shaped structure over the foramen magnum.

(14) Exoccipitals not meeting over the foramen magnum because they are separated by the dome-shaped portion of the supraoccipital.

\section{V1sceral Skeleton}

(15) Metapterygoid absent.

(16) Teeth trlcuspid, uniserial except for an occaslonal tooth or two outside the main row.

(17) Premaxdllary processes small and not extending over the mesial processes of the maxillse.

(18) Outer process of the maxilia more prominent than the mesial process.

(19) Branchiostegals arranged in two groups of six pairs in Cyprinodon, and Iive pairs in the other genera of Group I. 
Visceral Skeleton--Continued

(20) Third and fourth pharyngobranchials rused into one plate.

(21) Two ossifled basibranchials.

Other Regions

(22) Posttemporal forked.

(23) Transverse processes of the precaudal vertebrae amall and blunt but with prominent concavities distally for articulation with ribs.

(24) Median hypural consisting of a single fan-shaped plece

(25) Posterlorly directed bony processes of the pelvic bones elongated.

(26) Subcleithral (postcleithrum?) bone present.

(27) Haemal canals narrow.

(28) Prezygapophyses small.

(29) Supracleithrun present.

(30) Space between the eleithrum and the coracold narrow. 


\section{GROUP II}

\section{Composition, Range and Habltat}

The geographic range of this group includes countries around the Mediterranean Sea, the Red Sea and tha Arablan Sea (Inoluding the Persian Gule) up to the Gulf of Kutch.

The following genera are included:

Aphanius Nardo. About elght species.

Range: southern Europe, northern Africa and Asia Minor.

Habltat: fresh, brackish and marine 11ttoral waters.

Aphaniops Hoedeman. Monotypie.

Range: Red Sea cosst, the adjoining cosst of the Indian

Deean as far as Kutch and the Mediterranean Sea.

Habitats fresh, bracklsh and marlne littoral waters.

Anatolichthys Kosswlg and Sozer. Three species.

Range and habitat: certain lakes of Turkey.

Kosswiglchthys Sozer. Monotypic.

Range and habltats confined to Lake Hazer in eastern

Turkey.

$$
\text { (Figs. } \frac{\text { Osteology }}{24,25 \text { and } 26)}
$$

The following specles of Group II have been studied:

Aphantus gypris (Heckel), Aphanius sophiae (Heckel), Aphanius Pageiatus (Cuvier and Valenclennes), Aphanius chantre1 (Gaillard), 
Aphanfops dispar (Ruppell), and Anatolichthys transgrediens Aksirey. The osteologg of these species is much like that of Cyprinodon v. variegatus.

Ethmoid region

The nasals, the lateral ethmoids, and the vomer are normally positioned. There is no ethmoid ossification and consequently the mesethmoid is cartilagtnous.

Orbitotemporal region

The orbitotemporal region lacks parletals. The frontals are prominent and the supraorb1tal processes are comparatively wolldeveloped. Posteriorly these processes enclose between themselves and the sphenotic processes small notches for the postorbitals. The postorbitals are very small in A. phanius chantrel, A. phanius sophiae, and Anatolichthys tranggrediens, but in A. phanius gypris, A. phanius fasciatus and Aphanfogs dfspar these bones are more proninent. The postorb1tal is boat-ahaped and has an open groove for the lateral line sensory canal. The lachrymal is normally disposed. The altephenolds are present on either side of the cranfum. The parasphenold is normally located, its Inner processes are small and do not extend laterally to join the allsphenoids.

Otic region

The otic bones are disposed as in Croup I eyprinodonts and the opisthotics are absent. 
Occipital region

The occipital region is conposed of the usual four bones, the supraoceipital, the baslocolpital and the exocelpitals. However, the supraoccipital varies in its disposition in these cyprinodonts. With the exception of Aphanius sophlae and Anatollahthys transgrediens, In whlch the supraocefpltal extends posterlorly toward the foranen reagnum and forna a amall roof over it, the other species of Aphanius under discussion plus Aphanlops and Koswilglchthys have a supraocelpital which stops short of reaching the foramen magnum. Thus it is the exoccipitals (except in Aphanius sophiae and in Anatolichthys transgrediens) which make a major contribution to the side walls and roof of the foramen magnum. This is in contrast to the New World cyprinodontids in which the supraoccipital takes a considerable share in the formation of the foramen magmum by forming a dome-shaped structure over 1 .

Both the besioceipital and the excocipitals bear condyles for articulation with the Irst vertebra. This is in contrast to Gyprinodon and Its allies in wich the exocolpital condyles are absent. The structure of the neural splne of the firat vertebra varies in these species of eyprinodonts. In Aphanius chantrei and in Anatolichthys transgrediens there is a distinet neural spine while in Aphantus sophlae, Aphanius fasclatus, Aphanius cypris and Aphaniops diapar the tips of the transverse processes of the flrst vertebra are separate, although a transverse bony septum connects them below the tips. In Kosewigichthrs asquamatus there is no newral spine because the neural arches are separate throughout and fasl to meet above the neural canal. 
Moreover, in contrast to Cyprinodon and its relatives, the neural arehes of the flrst vertebre in speeles of eyprinodonts under diseusstion are separate from the occipital region and take no part in the articulation of the akwll with the vertebrel colvmen.

\section{Viscerel skeleton}

The quadrate and the autopalatine are diaposed as in Cyprinodon. The metspterggoid is absent, and a thin mesopterygold 1s applled to the quadrate and the autopalatine from behind.

The articular, the angular, and the toothed dentary are arranged as in Cyorinodon. In the upper jaw, the maxdllae and the prenadillee axe normally disposed. The premadillary processes are amall, and the outer process of the maxdlla are better developed than 1ts mesial process.

In Kosswiglehthys asquamatus the the unieuspld, blunt at their tips and arrenged in a band on both the premaxdlla ini the dentary. In all the other species In Croup II, hovever, the teeth are tricuspld with the adddle eusp the longest, and arranged in a single row. The middle cusp, moreover, is conleal in contrast to the New World eyprinodontids, in which this cusp is nat.

The hyomandibular, the symplectic, and the hrold cornu are normal. The hypohyal is represented by a single plece on each side. In Aphanfus fasciatus and Aphantops dispar, there are flve branchiostegals which are arranged in two groups. The first group contalns one ray and the second group has four. The other specles, 
Aphanius eypris, Aphanius chanterel, Aphanius sophiae, Anatolichthys transgrediens and Xosswlgichthys asquamatus, have four rays in the second group and none in the first.

The branchial skeleton consists of five arches having the usual number of segments. There are only two ossifled besibranchlals. The fourth ceratobranchlal is toothed in Aphantus cypors, Aphanius chantere1, Aphanius faseiatus, and Kosswigichthys asquamatus. In Aphanius sophiae and Aphantops dispar the fourth ceratobranchial is without toeth. The IIrst phargngobranchial 1s cartilaginous whlle the other three are ossifled and bear teeth. The second pharymgobranchlal Is separate, although elosely applied to the third and fourth pharyngobranchlals which are, however, fused into a single plate. The basihyel and the urohyal are normal.

The posttemporal is foriced in all the species of Aphanius under discussion and in Aphaniops dispar. It is unforked, hovever, in both Anatolichthys transgred1ens and Tosswigdchthys asquamatus. 
Summary of Signtflcant Osteological Characters

$$
\text { of Group II }
$$

Ethmo1d Region

(1) Mesethmoid cartilaginous.

(2) Vomer edentulous.

Orb1totemporal Region

(5) Parletals absent.

(4) Posterior myodome absent.

(5) Inner processes of the parasphenold mall and not in contact w1th allsphenoids.

(6) Postorbital small in Aphanius sophise, Aphanius chanterel, Anatolichthys transgrediens and Kosswlgichthys asquanatus but prominent in Aphanius fasciatus, Aphanius eypris and Aphaniops dispar.

Occipital Region

(7) Foramen magnum formed chieny by the bestoceipital and exoccipitals except in Aphanius sophiae and Anatollehthys transgrediens in whlch the supraoceipital extends backward to form a small roof over 1t. In no species of Oroup II, however, does the supraocelpital form a dome-shaped structure over the foramen magnum comparable to the one found in New World eyprinodontids.

(8) Both the basioceipital and exoccipital condyles well dereloped.

(9) Articulation of the first vertebra and the skull by the baslocelpital and exoccipital condyles. 


\section{Occipital Region--Continued}

(10) First vertebra bearing toward Its anterior end two proninent, concave, articulating facets for the exoceipital. eondyles; neural arches of the first vertebra separate from the occipital region. The tips of the Pirst vertebra. separate in Aphanius sophiae, Aphanius faseiatus, Aphanius eypris and Aphantops dispar although a transverse boxy spetum comnects the transwerse processes below the tips. In Anatolichthys transgrediens and Aphanius chantere1, distinct neurel spine present on the Irst vertebra. In Kosariglehthrs asquanatus neural spine absent because the nourel arches of the first vertsbra fall to meet above the neural canal.

\section{V1seeral Skeleton}

(11) Satepterggoid absent.

(12) Teeth tricuspld; midcle cusp longest; teeth in a single row except in Kosswletchthys ascuaratus in which the teeth are unicuspid, are arranged in a band, and are blunt at their distal extremities.

(15) Premadiliary proeesses gmall and polnted at the tips.

(14) Outer process of the maxilla ietter developed than the mestal process.

(15) Evpohyal a single pisce on each side.

(16) Five pafro of branchlostegals in Aphanius fasclatus and Aphantops dispar; four pairs in the other species. 
Viseeral Skeleton--Continued

(17) Third and fourth pharyngobrenchials fused.

(18) Two ossteled bastbranchlals.

$$
\text { Other Regions }
$$

(19) Posttemporal forked in all the speeles of Aphanius and in Aphaniops dispar; unforked in Anatollehthys transgredions and Kosswigichthys asquamatus.

(20) Transverse processes of the precaudal vertebres elongated.

(21) Median hypural consiating of a single fan-shaped piece. 


\section{RELATTONSHIPS OF GROUPS I AND II}

Regan (1917) Included both the New World and the Old World genera related to Cyprinodon and Aphanius in the subfamilly Cyprinodontinae. In diagnosing the subfandly he pointed out that its nombers possess exoceipitel condyles and trleuspid toeth but lack parietals. He (op. c1t.: 323) surther stated that the Cyprinodontinae "Differ from the Funculinae only in the tricuspld teeth and the absence of parletals."

Hubbs (1926) mentioned that parietals were present in Cyprinodon bovinus and Floridichthys earpio and Myers (1951) maintained that the parietals were present in Cyprinodon varlegatus riverendi. Concerning the presence of the basisphenold in the latter species and in Forldichthys carp10, Myers (op. e1t.s 252) wrote that the "Baslsphenold [1s] present, at least In I. carp10." On the basls of the remarks by Hubbs and his own observations of the parietals, Myers thought that the tricuspld teeth were the only diagnostic character of the subfandly Cyprinodontinae. In this connection he (1oc. e1t.) remarked that "Ihe tricuspid toeth distinguish this group from all others here considered. AsIde from this they [Cyprinodontinae] appeas to differ little from the Fundulinas." Consequently in 1951, he Included Cyprinodon, Floridichthys, Jordanella, Aphantus and Tellia In the subfandly Cyprinodontinae but Hoedeman (1951) has stnce synonymired Tell1a with Aphan1us. 
Weamihtle Kosswlg and Sozer (1945) described a new genus, Anatollehthrs, from Turkey and because of its trieuspid teeth it uarally has been included in the subfandly Cyprinodontinae (Steinitz, 1951; Miller, 1956). Another new Turkdsh gemus, Xosswlglehthys, deseribed by Soser (1942), has untouspld teeth and therefore was first thought to be a nember of the cubfandly Funculinee. However, experimentel hybridization and cytologioal studies by Aksiray (1952) and Oztan (1954) produced strong evidence that Kosswlgichthys actually is more alosely related to Aphanius and Anatollchthys despite the fact that both of these latter genera have trleuspld toeth.

Kifler (1956, 8) while discussing the relationships of Cualac, a Mexican genus with tricuspid teeth, remariked that "Cualae nay well be closely related to Fundulus, with conleal teeth, as to the eyprinodontids, with trieuspld teeth." Hie proposed, therefore, that the two subfamilles Cyprinodontinse and Fundulinae be united into one subfanlly Cyprinodontinae.

It has already been pointed out, in connection with the description of the esteology of Group I, that the New World genera with trleuspid teeth lack exoceipital condyles. Therefore, Regan's (1912) conclusion regarding the presence of excocipttal condyles in New World Cyprinodontinee is not eorrect. Since New and Old World genera with tricuspld teeth (Groups I and II) diffor from one another not only in the presence or absence of exocelpital condyles, but also In other fundamental characters presentily to be discussed, it is ov1dent that in the past these two different phyletic entities have been confused under the subfamtly Cyprinodontinae. 
Both Hubbs (1926) and Kyers (1951) appear to be in error in pointing out the presence of parletals in Cyprinodon and in Moridichthys, for in the three species of Cyprinodon, which I have studied and In Floridichthys carpio, these bones are absent. Further, the parletals are also absent in Jordanella, Garmanella, Cualac, Aphanius, Aphaniops, Anatollehthys and Kosswlgiahthys. Simllarly I have found that the baeisphenoid is not oniy absent in Moridichthys but it is absent also in all other cyprinodonts under consideration in this study. Concerning the relationships of Kosswiglchthy, the oateologIcal evidence is in harmony with the views of Akairay (1952) and Oztan (1954) who, on the basis of experimental hybridization and eytological studies, concluded that Kosswlglehthye is related more closely to Aphantus and Anatolichthrs which have trieuspid teeth than to Valoncla which has conical teeth. Absence of parietals and the cartilaginous nature of the mesethmold are the two characters which I cite in mupport of my Interpretation of the elose relationship between Kosswiglehthys and Aphanius.

Miller (1955, 1958) auggeated that the two subfandlies Cyprinodontinae and Fundulinae be unitad into one subfamily Cyprinodontinae. In this comnection it might be pointed out that there are aeveral fundamantal differences between the Nev World eyporinodont1ds with tricuspid teeth (Group I) and the Funculids with conical or bicuspid teeth (Group III). These differences relate not only to the nature of teeth but also to differences in the first vertebrae, the premadillary procesees, the maxdilary processes, the ocelpital condyles, 
the posttemporals, and the parietals. Therefore, Croup I and Croup II represent two distinct phyletie 1ines easily separable from each other on the basis of major osteological differences. However, the subfandlies Cyprinodontinae and Tundulinse as delimited by Nyers (1951), and as understood by most subsequent authors, contain heterogenous phyletic ent1ties which have been confused under these groups. For example, the Old World genera, Aphanius, Aphaniops, and Anatollehthys (all with tricuspid teeth), and Kosswiglehthys (with unieuspid teeth); and the New World genere, Cyprinodon, Morla4chthys, Jordenella, Garmanella, and Cualac (all with tricuspld teeth), have been grouped under the subsantly Cyprinodontinae, although they form two phyletic entities when their osteological characteristics are considered. Similarly, as will be shown presentily, the New World genera related to Fundulus (conical or bieuspld toeth) and the Old World genus Valencia (conical teeth) also possibly form two separeto phylet1e entit1es and should not be grouped together in the same subfamlly as has been the practice in the past. Therefore, in order to make the elasalfieation of the genera now grouped under two subfamillies Cyprinodontinas and Tundulinae, a natural one, four groups should be recognised. They ares

(a) The New World genera with trieuspid teeth

(b) The Old World genere with tricuspid or unieuspid teeth

(c) The New World genera with conical or bicuspld teeth

(d) The OId World genue Valenele with conical teeth

This grouping of genera was antileipated by both Hoedoman (1951) and Miller (1955, 1956). Hoedeman (1951, 1), wh1le attempting 
a rediagnosis of the Old World eyprinodont genus 1 phantus, ramarked: "We found the Old World genera and specles . . . to be closely related, and doubtless forning a phyletic unsty, quite well separable from the New World genere of this subfamily [Cyprinodontinae]." Hoedeman (1951: 1-2) separated the New and the OId World genera In two tribes, Aphanild and Cyprinodontid, and listed the following characters distinguishing thems

"I. Teeth tricuspid, IIddle eusp the longer, usually sharply pointed, side eusps amell; preorbital margin rather narrow, usually one-half ege diameter or 1ess, but not as narrow as in RIvalids, preorbital [premeadliaries?] not FIrmiy united, in contact with each other for only one third or leas of the Inner margin, the beckwerd directed processes narrow, . . tribe Aphanilds Hoedenan, 1949.

II. Teeth trleuepld, middle cusp not always the longer, usually spatulate, not polnted as in Aphanilni, preorbital margin more than one-half eye dismeter, premaxdluarles IImly unitod, in contact with each other for nearly the entire inner margin, the backward directed processes rather broad ... tribe Cyprinodontids Hoedeman, 1949."

Miller (2955: II) remarked about Valeneia, of the fresh waters of Spain: "An exardnation of specirems of Valencia hispanice and syntypes of V. 1otourneudi eonviness me that this genus is a general1zed, independent derivative probably not elosely related to any New World genus." Agaln while discuseing the relationships of the gemus Cualae, Miller (1956: 9) commented: "It 1s ontiroly posedble 
that the Old World genera with tricuspld teeth have been independently derived from ancestors there and are not intimately related to their New World representetives."

The results of the current study tend to support the conclustons of Hoedeman (1951) and Miller (1955, 1956) concerning the Independent derlvation of the Old World aphanids, valenclds, and the New World cyprinodont1ds and fundulids from ancestors in their respective areas. Since no conclusive evidence has been advaneed previously in support of the independent derivation of the Old World and New World eyprinodonts with trieuspid teeth, the osteological charscters in which the two groups differ from each other are l1ated in Table 6.

A perual of the list of differences shown in Table 6 mekes It evident that the Old World gener (Aphanius, Aphaniops, Anato1ichthys and Kosswigichthys) differ markedily from those of the Now World (Cyorinodon, Foridichthys, Jordanella, Garmanella, and Cualac). Further, the Old World genere under conslderation appear to be more elosely related to geographically wldespread aplocheillds than to the New World genera. This relationship is based upon the fact that both the aplochellids (to be deseribed later) and the members of the old World genera posseas exoecipital condyles, have a cartilaginous mesethmoid, and simflar flrst vertebrae.

One possible explanation for this relationship is that some ancestral aplochellid-like stock gave rise, In the O1d World, to the genus Aphanius or Aphaniops which in turn produced Anatoliehthys and Kosswiglehthys. More recently Konuralp (2955: 117) from a study of 
TABLE 6

COMPARTSON OF NEW WORLD AENERA (GROUP I) AND

OLD WORLD GENERA (GROUP II) OF CYPRINODONTS

New World Genera (Group I) Old World Genera (Group II)

(Cyprinodon, Foridichthys, (Aphanius, Aphantops,

Jordanella, Garmanella, Anatolichthys and and (ualac) Koswiglchthys)

\section{Exoceipital Condyles}

Absent

Present

Foramen Magmune

Formed by basioccipital, supraoccipital and exoccipitals

Formed almost entirely by basioccipital and exoccipitals

\section{Supraocelpital}

Extends posterlorly to form a consplcusous dome-shaped structure over the foramen magnum
Rarely reaches the foramen magnum and never forms more than a minor and almost imperceptible portion of lts roof

Mesethmo1d

Ossified and composed of double lamines

Cart1laginous

First Vertebra

Articulates with skull by the basiocelpital condyle and neural. arehes

Neural arches applled to or even ossifled with oceipital region

No distinct gap between Prst and aecond vertebrae
Articulates with sloull by the basloceipltal and exocelpitel condyles

Neural arches separate from skill

Distinct gap batween flrst and second vertebrae 
embryonic development of the gonads and their relationshlps to other organs in four species of Aphanius, Kosswiglehthys asquanatus, and Anatolichthys transgrediens coneluded that Anatollchthys, Kossw181chthys, and Aphanius chantere1 have ardsen as a result of hobridization. 


\section{GROUP III}

\section{Composition, Range and Habitat}

Group III is confined to the New World and, except for a few forms found in Bermuda, Cuba and Jamalca, its representatives occur mainly in North and Central America. The following genera are Included: Fundulus, Ad1nia, Lucania, Chriopeops, Leptolucania, Bapetrichthys, Crentehthys, Profundulus, Cubanichthys, Chriopeo1des, Oxysygonectes and Mubbsichthys.

Fundulus Lacepede. About 35 currentiy recognized species and subspectes. Range: southeastern Canada, wost of the United States, the Bermuda Islands, Cuba, and Culf coastal areas of Mexico as far south as the Iucatan Peninsula. Habitats fresh and salt water from upland streams to marine ilttoral situations.

Adinia Girard. Monotypic.

Ranger Gulf Coast of the United States from Forida to Texas.

Hebltat: shallow lagoons along the cosat. Lueania Girard. Monotypic.

Ranges along the Atlantic Coast from Connecticut to Mexico.

Habltat: brackdsh water, Invading fresh water for some distance. 
Chrlopeops Fowler. Monotypic.

Range: endemice to Moride.

Habitat: mall ponds, streams, and ditches.

Leptolucania Myers. Monotypic.

Range: southern Georg1a and Florida eastward from the Appalachicola River Basin.

Habitat, fresh water swamps, streams and ditches. Theterlehthrs Gilbert. 2 species.

Ranger confined to the Death Valley region of Nevada.

Habitat: desert warm springs, frequenting the deeper holes; usually uncomion in shallow spring-fed ditches or marshy arees.

Crontahthys Hubbs. 2 species.

Ranger restricted to Central Nevada.

Habitat: warn springs.

Profundulus Mhbbs. 5 species.

Range: along both slopes of Middle Anerica from near Acapulco, Mexdeo, to western Ilonduras on the

Prelfic side and from the Isthnus of Tehuantepec to Rlo Motagua, Chatomala, on the Atlantis slope.

Habitati restricted to freah water and typically inhabit-

Ing the mountaln streams of Middle Americe where

they are most abundant at altitudes between

3,000 and 7,000 feet. 
Cubanichthys Hubbs. Monotyple.

Range: appears to be confined to the Island of Cube.

Chriopeoldes Fowler. Monotypic.

Range: Jamalea.

Oxyrygonectes Fowler. Monotypic.

Range: along the Pacifle Coast of Costa Rica.

Hab1tat: salt and brackish waters.

\section{Osteology}

The account $1 \mathrm{~s}$ bsed on a study of sixteen species representing eight of the eleven genera comprising the group. Representatives of the genera Cubanichthys, Chrlopeo1des and Oxyzygonectes were not avallable. The species studied are listed below:

Bundulus chrysotus (Ounther), F. grandis (Baired and Girard), F. gimills (Batred and Girard), ‥ confluentus Coode and Bean, F. nott1 (Agassiz), F. elngulatus Cuvier and Valenclennes, $F$. olivaceus (Storer), I. kansae Garman; Adinla xenlca (Jordan and GLlbert); Lucania parva (Baired and Girard); Chrlopeops goode1 (Jordan); Leptolucania amata (Jordan); Empetrlchthys latos Miller; Crenichthys nevadae Hubbs, Crenichthys baileyi (ailbert); ProfuncuIus hildebrandi Mller.

Head Skeleton

The head skeletons (FIgs. 27, 28, 29 and 30) of the genera in Group III compare favorably with that of Cyprinodon except for certain structural differences and the presence of additional bony elements. 
These additional elements and differences will be omphasized in the following discussion which relies on the previously given deacription of Cyorinodon for comparison and reference.

The head skeleton in these genera is longer than deep. The skull is unlformly broad due to the develogment of prominent supraorbital processes of the frontals. These processes are flat and completely cover the eyes from above. The Interorbital width in the middle orbital region is about the same as between the outer edges of the pterotics except in Lucania, Chriopeops and Leptolucania where the interorbital region is narrow. The orbitotemporal region has a pair of distinct parietals. The premadilary processes are elongated and extend posterloriy over the meslal processes of the maxdllae. The eplotics bear posterlorly directed eplotic processes of varlable extent. The epiotic processes are absent, however, in Adinta and Leptolucanis. The neural arches of the flrat vertebra in all the genera under consideration are separate from the skull.

The general shapes of the skulls and their proportions suggest three distinct evolutionary trends in the genera of Croup III. The detalls and the phylogenet1c signifleance of these three trends will be discussed after the osteology of these genera has been presented.

Sku11

The skull (M1g8. 51, 82, 35 and 54) will be descrtbed under the ame four headings uaed for Cyprinodon: ethmold reglon, orbitotomporal region, otle reglon, and occipital region. 
Bthmoid region

The ethmold region is atullar in most respects to that of Grorinodon and the geners closely related to 1t, Insofar as the mumber and diaposition of bones and cartllages are concerned. The major differences relate to the mesethmold and the vaner.

As compared to Cyprinodon, the mesethmoid is more prominent in all these genera. It is situated in the anterlor ethmoid cartilage, is elosely applied to the dorsal ourface of the vamer and is composed of double landnse. The mesethmold In Profundulus, Bmpetrichthys and Crenichthys (FIg. 55C) Is Large and comss in contact with the lateral athmo1ds on both s1des. In the remaining genera, Fundulus, AdInta, Lueania, Chrlopeops and Leptolucania, the mesethmold Is small and does not come in contact with the lateral ethmoids.

The vomer in Profundulus, Empetrlahthys, Cronichthys, Adinta and Leptolucania falls to meet the lateral ethmoida. In Fundulus, Lucania and Chriopeops, on the other hand, the vomer comes in contact vith the lateral ethnoids through its posterolateral processes.

Orbitotemporal reglon

The orbitotemporal region has a pair of parletals which are situated obliquely on elther side of supraocelpltal and Imadiately behind the frontals. Anterolaterally each parietal comes in contact with the sphenotic and the pterotic vilie posteriorly it 18 in contact with the eplotic and the supraoecipital.

The frontals oecupy the same position as in Cyprinodon. In Profundulus, Fundulus, Empetrichthys, Crenichthrs and Adinia the 
supraorbltal processes of the frontals are well developed, Ilattened dorsally and cover the eyes completely. In Lucania, Chriopeops and Leptolucanta, on the other hand, the supraorbital processes are less well developed, are convex dorsally, and do not cover the eyes completely.

The perasphenold is almilar to the one in Cyprinodon except for 1ts anteralateral processes, which in Profundulus, Fundulus, Mmpetrichthrs and Crenichthys extend laterally to meet oinilar extenslons from the allaphenolds to enelose a posterlor wyodome on each side.

The posterior myodone is formed in three different ways in the several genere under consideration: 1. In Ampetrichthrs latos, Funculus cingulatus, and Fundulus kansse, the antorolaterel process of the parasphenold meets a process form the allsphenoid on each alde and thus enclose a rather wide gyodomes in these specles the prootic does not contribute to the formation of this structure as it does in Profundulus, Crentehthys, and several species of Fundulus. 2. In Fundulus nott1, the anterolateral process of the parasphenoid meets the mesial process of the prootic to enclose a myodane and there is no conzetition between the parasphenold and the allsphenosd. 3 . In Profundulus hildebrands, Crenichthys nevadae, Creniehthys badleyl,

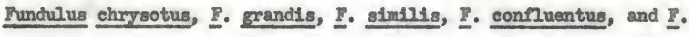
olivaceus the anterolateral process of the parasphenold meets an oxtension of the alisphenold on each edde; in addition, the prootic sonds amall anteromesial process which joing from behind the extensions of the parasphenold and the allsphenold at a place where the 
latter join one another. In this manner a comparatively small mpodome is enclosed internal to these processes.

In Adinta, Lucanta, Chrlopeops, and Leptolucanta the posterlor myodome is absent. In these genera the allaphenolds have no connection with the anterolateral processes of the parasphenoid which, as in Cyprinodon and 1ts alles, are located on the inner aspect of the parasphenoid. A fev minor modifleations are to be noted in this connection. In Adinia a mesial extension of the prootic is present, although neither this extension nor the anterolateral process of the parasphenold and the allaphenold join one another. In Lucanta, although the anterolateral process of the parasphenold does not join the allsphenold, a mesial extension of the prootic joins the alsophenold. Both the lachrymal and the postorbital are normally disposed. The postorbital 11 s in a notch of the frontal which is positioned In the posterlor corner of the skull where it is wedged between the well developed supraorbital process of the frontal and the sphenotic. The postorbital Is more anterlorly placed than that of Cyprinodon, and takes part in forming the posterlor boundary of the orbit. The postorbital Iles anterior to the sphenotics in contrast it $11 \mathrm{~s}$ external to the latter bone in Cyprinodon. The postorbital is a boatshaped bone with an open sensory canal on Its external surface. The lachrymal in Bmpetrichthys and Crantehthys is narrover than in the other genera under discussion. Both the bestaphenoid and the orbitosphenoids are absent. 
otic region

The otic region is sintlar to that of Cyorinodon in almost all esaential respects. There are, however, a few differences in detalls.

In severel genera the eplotics bear posteriorly directed eplotic processes on their posterlor dorsal extremities. These processes are large and branched at their distal extremities in all the species of Funaulus under consideration and also in Profundulus hildebrands; mall to falrly prominent in Chriopeops; amall and pointod (9 speeimens) to absent (9 specimens) in Iucands, small and stumpy in both species of Crentchthys, Bupetrichthys latos; and absent in Adinie and Leptolueanla.

The prootic is prominently developed and sends an anteromesial. process which, along with the anterolateral proeess of the parasphenoid and the allophenold, contributes to the formation of the prevlously described posterlor nyodowe. In Bmpetrlehthys latos and two speeles of rundulus, F. cingulatus and F. kansae, however, the anteromegial process of the prootic is lacking. In the other six species of Fundulus, in both the species of Crenichthys and in Profrmdulus hildebrand1, an anteromealal process of the prootlc is present. In Chrlopsops and Leptolucanis neither the parasphenold, the allsphenoid or the prootic extends mosially to join each other. In Adinia, although an anteromesial process of the prootic 18 present and the anterolateral processes of the parasphenold and the allaphenold are prominent, none of these processes join one another. In Ilucanta the anteromestal process of the prootic joins the alsphenold but the 
anteromesial limb of the parsaphenoid and the allsphenoid are separate. Other features of the prootlc are similar to those of Cyprinodon. This Is also trus of the pterootic and the sphenotic. As in Croups I and II, the opisthot1es are absent.

Oecipltal region

The occipital region, as in Cyprinodon and Its allies, is made up of four bones, a supraocelpital, a basloceipital and two exrocelp1tals, which make up the posterior region of the skull. The foramen magenum is formed entirely by the basloecipttal below and the excocip1tals which contribute not only the side walls but also the roof. The supraocelp1tal stops short of reaching the formen magnum and, therefore, does not take part in 1ts formation. The exoceipitals bear prondinent condyles for articulation with the PIrst vertebra (IIg. 35B). The relationships of the ocelpital bones with the remainder of the skull are similar to those in Cyprinodon except that, in all the genera under consideration, the supraocelpital not only comes in contsct with the frontals but also with the parietals.

Unlike the situation in Cyprinodon and Its allies, the neural arches of the firgt vertebra remain separate and are not applied to the occipltal region ( $M g$. 44). The skull articulates with the first vertebra by both basioccipital and excoecipltal condyles.

V1sceral skeleton (F1g8. 85A, 56B, 86C, 37, 88, 59, 40A, 40C and 41) Mandibular arch

Except for gome signifleant differences in the shapes of certain bones, the mandibular arch 18 much like thet of Gyprinodon. 
One difference concerns the maxd11a whlch is consistently different from that of Cyprinodon. In Group III the outer process of the maxilla is less conspleuous, but its mesial process is better developed, more elongate, and supports the elongated premadilary process from below (F1g. 35A). This is designated the rundulid type of madila in contrast to the cyprinodontid typo as exemplified by Cyprinodon and 1ts allies of Croup I.

The premadjiae are produced into more elongate premeadiliary processes in contrast to Cyprinodon and 1 ts a321es whlch beve small premaxdllary processes. The teeth are of two types, btcuspid in Crenlchthys and conical in all the other geners. Because the structure and arrangement of the toeth are useful in generic aegregation, a sumuary 18 glven for those specles of Aroup III which have been examined in this atudy (Table 7).

Hyold arch

The bones of the hyold arch are similar to those in Cyprinodon and the hypohyal on each side is represented by a single bony plece. The structure and arrangement of the opercular bones resemble the pattern in Cyprinodon and 1 ts allies. The number of branchiostegals, however, dffer in different genera comprising Group III as shown in Table 8. 
TABLE 7

COMPARISON OF TOOTH STRDCTURE AND ARRANGPIENT OF JAW TEETH II SEVERAI, SPECIES OF GROUP III CYPRINODONTS

Specles

\section{Arrangement of Teeth on Promediliary and Dentary}

With Conical Teeths

Profundulus hildebrand1

Fundulus (all elght species In this study)

Adinia xenica

Lucania perva

Chrlopeops goode1

Leptolucania onmats

Empetrichthys latos

With Bieuspld Teeth:

Crentehthys baileyl

Crenichthys nevadae
Arranged in a band, outer row of large and several Inner rows of small teeth

Same as Profundulue

Same as Profundulus

One row of conical teeth

Two rows of conical teeth

Same as Chrlopeops

Outer row of large and an Imner row of small teeth

Outer row of large bicuspid and two Inner rows of small conical teeth

Outer row of large bleuspld and one inner row of gmall conical toeth 
TABIE 8

NUMBER OF BRANCHIOSTEGAL RAYS IN SELECTED SPECTES

OF CROUP III

Species

and Number of Specimens

Number of

Fxamdned

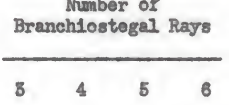

Fundulus chrysotus (7)

F. grandis (5)

5

F. similis (4)

4

F. confluentus (6)

6

I. nott1 (4)

4

E. cingulatus (5)

5

I. olivaceous (4)

4

F. kansae (4)

4

Lucanta parva (16)

115

Chrlopeops goodes (4) t

22

Leptolucania omata (10)

10

Empetrichthys latos (2)

2

Crentchthys basleyl (2)

2

Crentchthys nevadae (2)

2

Profundulue h1ldebrandi (4)

4

In two other specimens of Chrlopeops goodel there were 5

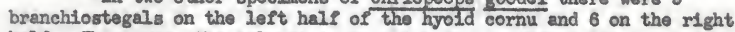
half. These were the only cases in which the counts varied from side to side in any of the species examined. 


\section{Branchial arches}

The number of branchial arches and the bones composing them are similar to those of Gyprinodon. The differences relate chiefly to the number of gill-rakers and to the extent with wich the fourth ceratobranohial is provided with teeth. There are two osstifled basibranchials and four eptbranchtals. The first pharyngobranchial is cartilaginous and lacks teeth while the other three are osslfled and bear teeth. The second pharngobranchial is separate but the third and fourth are fused into a single plate. The basihyal and the urohyal are normal.

Because characteristios associated with the pharyngeal bones have been utilized in generie segregation by several authors, these bones warrant a special mention. Gilbert (1893 P1. 5) published a fIgure of the pharyageal bones of Fimpetrichthys merriand and since then Carman (1895: 116), Hubbs (1932: 8) and Milller (1948: 99-100) have characterized the genus Impetrichthys solely on the nature of 1ts pharyngeal bones. Miller (100. c1t.) in diagnoaing the genus Bmpetrichthys reported that the "Jpper and lower pharyngeal bones [are] greatiy enlarged [and] the lower pharyngeals [are] completely united." He reported also that "The tubercular-shaped molar teeth and the greatly enlarged upper and lower pharyngeal bones are the most distinetive characters of the genus."

In Empetrichthys latos the pharymgeal bones are normel in that they are neither greatly enlarged nor are the lower pharyngeals 
united with one another. Moreover, the teeth on the upper and lower pharyngeals are distinctly conteal. Therefore, the generic diagnosis of Bmpetrichthys as proposed by Garman (1895), Hubbs (1932) and Meller (1948) is untenable and requires revision. Complete diagnosis of the genus gampetrichthys, however, cannot be undertaken here due to the lack of pertinent material. In the present study the pharymgeal bones of twenty-eight genera of eyprinodonts have been examined and It was found that the use of characteristics associated with these bones have littie value in separating genera. In no eyprinodont have I found the lower pharyngeals to be united completely. The lower pharyngeals are always separate although there is variation in the amount of spacing between them. The lower pharyngeals are very close together in Orestias agass1211 (Group VIII) Lucania, Chr1opeops, Leptolucanta, Garnanelle, Cualas and the aplochellids (Croup V). In all the other genera examined, including Empetrichthys, there is a distinct space between the lower pharyngeals.

The posttemporal 1s forked in Profundulus hlldebrandi, Bmpetrichthys latos, both the species of Crenichthys, and Pundulus kansae. Moreover in these specles, a thin membranous bony lamina extends between the lower end of the two limbs of the fork (F1gs. 4OB, 42 and 43). The posttemporal is unforked, however, in all the remalning spectes of prundulus under constderation, as well as in Lucania, Chriopeops and Leptolucania. 
Summary of Significant Osteological Characters of Group III

Ethmo1d Region

(1) Mesethmoid ossified and composed of double laminae.

(2) Vomer edentulous.

Orbitotemporal Region

(3) Parietals present.

(4) Posterior myodome present except in Adinia, Lucanta, Chriopeops and Leptolucania.

(5) Anterolateral processes of the parasphenold share in the formation of the posterior ayodome except in Adinia, Lucania, Chrlopeops and Leptolucania.

(6) Interorbital area of the frontals rectangular, supraorbital area well developed and nattened dorsally except in Lucania, Chriopeops and Leptolucania in which the interorbital area is somewhat triangular and the supraorbital area is small and slightly convex dorsally. Oceipital Region

(7) Occipital region of the skull not in intimate union with vertebral column; no distinct gap between the f1rst and second vertebrae.

(8) Articulation of the skull with the firgt vertebra is through a basioceipital and two exoccipital condyles; neural arches of the first vertebra separate and take no part in the articulation. 
(9) Exoccipital condyles well developed.

(10) Foramen magnum formed entirely by exoccipitals;

supraoccipital not reaching foramen magmum.

(11) Supraoccipital not forming a dome-shaped structure over the foramen magnum.

(12) Exoccipitals meet over the foramen magmum.

\section{Otic Region}

(13) Epiotic processes present in all genera examined except Adinia and Leptolucanta.

\section{Visceral Skeleton}

(14) Metapterygoid absent.

(15) Teeth conical or bicuspid.

(16) Premexdllary processes of three types: short and broad Profundulus short and narrow Empetrichthys and Crenichthys long and narrow Fundulus, Adinie, Lucania, Chriopeops and Leptolucania.

(17) Maxilla with a well-developed mesial process and weakly-dereloped outer process.

(18) Hypohyal represented by a single bony piece on each side. (19) Branchiostegals 8, 5 or 6.

(20) Third and fourth pharyngobranchlals fused into one plate. (21) Two ossifled besibranchials. 
Other Reglons

(22) Posttemporal unforked except in Profundulus, Impetrichthys and Creniohthys; in Fundulus kansae It is forked and the processes of the fork are jolned by a bony lantna towards its lower end.

(25) Transverse processes of the precaudal vertebrae elongated

(24) Posterlorly directed bony processes of the pelvic bones sma11.

(25) Subcleithral bone present in all the genera except Laptolucania.

(26) Haemal canals wide.

(27) Prezygapophyses prominent.

(28) Median hypural elther clearly divided into parts by a suture or shows indications of such a dividion (Profundulus, Empetrichthys and Crenichthys). In other genera of Group III, median hypural is a single, fan-shaped plece with no indications of division.

\section{Relationships of Group III}

The genera which have been delinited in Oroup III show suffcient sinilarities relative to their ostoological characters and geographical distribution to suggest that they form a phylet1c unity. In addition, the members of Croup III appear to be related to the widespread aplochellids which are to be described later under Group V. The characters shared by members of Group III and Croup V are summarized under two heads to show the points of agreement and disagreement. 
1. Osteological characters common to Croup III (fundulids) and Group V (aplochellids)

(a) Skull long and uniformily wide.

(b) Parietels presento

(c) Interorbital area of frontals rectangular; suproorbital aree well developed, dorsally flattened and covers eyes completely.

(d) Foramen magnum formed entirely by exoceipitals; supraocolpital not reaching the foramon magnum.

(e) Supraoceipital not forming a dome-shaped structure over the foramen magmum

(f) Excoceipital concyles well devoloped.

(g) Articulation of the skull with the f1rst vertebra by a basioceipital and two exoceipital condyles

(b) Neural arches of the first vertebra separate from the skull

(1) Teeth conical; arranged in a band; outer row large.

(j) Promaxdllary processes short and broad.

(k) Maxdlle with a well-developed mesial process and weakly-developed outer process.

(1) Posttemporel forked or unforked.

(m) Transverse processes of the precaudal vertebrae elongated.

(n) Posteriorly directed bony processes of the pelvic bones small

(o) Haoval canels wide 
(p) Median hypural either clearly divided into parts by a suture or indication of such a division ovident.

2. In certain other osteological characters fundullds (Oroup II) deffer from aplochellids (Group $V$ ) and thus either stand apart or show resemblences to cyprinodontids (Group I). These characters aro:

(a) Mesethmold ossteled and composed of double laminae.

(b) Vomer edentulous.

(o) Two bastbranchtals.

(d) Posttemporal forked (at least in Profundulus, Bmpetrichthys, Crenichthys and Fundulus kansae).

(e) Median hypurel composed of single fan-shaped plece without any indications of division.

In the structure of the first vertebre the fundullids are entirely and consiatently different from all other eyprinodonts which I have examined. The neural arches of the first vertebra in the fundullds are separate from the occipital region and never meet above the neural canal to form a neural spine. In Produndulus, and In some specimens of Crentchthys balleyl there is, however, a thin bony septrum which connects the neural archer of the first vertebre just below their separate tips. Although no suah bony septum connects the noural arches of the Iirst vertebra in each of the two specimens of Crentehthys nevadae and Bmpetrichthys latos wich I have cleared and stained, It is possible that an examination of a larger series of these two species might reveal a flrst vertebra of the type found in Profundulus and Crentehthys baileyl. 
It 18 apparent from the 11st of osteological characters given above that the New World Sundurlds (Group III) show a close relationahlp to the videspread aplocheilids (Group V) on the one hand and to the New World cyprinodontids (Group I) on the other. The distribution of the aplochellids (Group v) is a southerly one, principally African, South American and to some extent South AsIan. This southerly occurrence resembles the southern, peripherel distribution of the more primitive nembers of mang groups of terrestrial and fresh water vertebrates and invertebrates. Moreover, as wlll be shovn in conneetion with the description of Group V, the aplochell1de present by far the largest number of basle osteological and other characters that have become speclallsed or even lost in other groups. Thus in the Fundulids (Group III) under discussion, an ossifled mesethmold composed of double laminae seems to be a modifleation of the cartilaginous mesethmold found in the aplochellids. Similarly, the sirst vortebre of the fundulids is without a neural spine and may well have been derived from that of some aplocheilld-1ike stock whlch had a normal Ilrst vertebra and neural spine. After the evolution of a vertebre. In which the neural arches do not meet above the neural canal to form a neural spine, it 18 easy to Nisualize further modifleations of the first vertebra leading to the condstion found in Cyprinodon and 1ts allies (Group I). For example, in a fundulid-11ke stock with 'free' neural arches it could be supposed that these arches became applied to the ocelpital region as functional articulations. These artieulations would then provide the type of skull-vertebral colum relationship 
found in Croup I especielly in the event of subsequent loss of the excocipital condyles and the parietals.

Another structure in fundulids which seems to be a modification from the aplochellids relates to the modian mypural. The nedian hypural is a bifld or trifld structure in the aplocheilids while in the runculids it 18 a single fan-shaped element except that in certain geners (Profundulus, Brapetrichthys and Crenichthys) 1t still shows Indications of a bifid nature.

The lack of vomerine teeth and the absence of a metapterygold may be mentioned as an example of the structurea which have been lost In fundul1ds but are st1ll present in aploohe1lida.

Thus both the distributionel and the osteologieal evidence Indicate that the aplocheilids gave $\mathrm{MIse}$ to the fundulids and that In their turn, the fundurlds produced the New World cyprinodontide. These and related matters will be discussed more fully following the deseription of the osteologleal characters of all the groups under consideration.

\section{Evolutionary Trends Within Group III}

WIthin Croup III two, and posalbly three, evolutlonary IInea are apparent on the basis of osteological characters. As was mentioned earlier, the general shape of the skul and Its proportione suggest three evolutionary trends in the genera Included in Croup III. These trends ares

(1) In Profundulus, Bupetrichthys and Crenlehthys, the supraorbltal processes of the frontals are well developed and eover the 
eyes completely, the eplotics are broad and slope gradually toward the pterotics which 11 e at about the same level as the epiotics.

(2) In Pundulus and Adinia although the supreorbital processes are well developed and cover the eyes completely, the eplotice are narrow, constricted in the middle and form a distinct oplotic erest on both sides; the pterotics 11 e at a considerably lower level than the epioties.

(3) In Lucania, Chriopeops and Leptolucania, in addition to a simisar disposition of eplotics and pterotics as in Fundulus and Adinia, the supraorbital processes of the frontals are less developed, they are sllghtly convex dorsally and fall to cover the eyes completely. Moreover, in these three genera, the interorbitel width in the middle orbital region is less than between the outer edges of the pterot1es.

Further, it becones all the more clear that Profundulus, Finpetrichthys and Crenichthys form a phyletie unity within the group, when It is considered that these three genera seem to share many fundamental characters and that these same characters are absent in 211 the other genera of the group under consideration. These characters are:

(a) The genital pouch is either absent or obsolete (absent in Empetrichthys and Crenichthys and weak to obsolete in Profunculus).

(b) The dorsal and anal fins are posterior (the origin of the dorsal being over or almost over that of the anal) and 
except for the pelvic fins (absent in Bampetrichthys and Crenlehthys) all IIn ray counts overlap.

(c) Premadillary processes are short and wide in Profundulus, short and narrow in Bmpetrichthys and Crenichthys, while In all the other genera of Croup III these processes are typically long and narrow.

(d) The gill-rakers are numerous, about 14 in Mmpetrichthys, about 16 to 28 in Profundulus and about 27 in Creniahthys while in all the other genera of Group III (except for Adinia which has about 16), the number of gill-rakers is about 6.

(e) Mesethmold is large and in contact with the lateral ethmo1ds.

(f) Vomor is not in contact with the lateral ethmoids.

(g) Median hypurel 18 either clearly divided into two parts by a suture or shows indications of such a division.

(h) Posttermporal is forked and the two $11 \mathrm{mbs}$ of the fork are united by a bony lamina toward their lower ends.

(1) Mmber of vortobrae is uvually more than the other genera of Croup III, 28 in Crentehthys batleyl, in in Mpetrlehthys latos, 36 in Prorundulus hildobrandi and aceording to Miller (1955 : 11) Profundulus has 31 to 39.

(g) Neural arches of the first vertebra do not meet above the neural canal to form a neural. spine, but a transverse bong septum connects the neural arehes fust below their tips. 
Although Profundulus of the Merdcan Plateau eurrently shows a disjunct distribution with Bmpethrichthys and Crenichthys of Death Valley, Nevada, this, as in many other primitive forms, may not have been always the case. In this connection the following remarks of Miller (1955: 16) seem pertinent; "We eamnot be certain, for example, that pundulus detillat and Fundulus sternberg1, as described by Hibbard and Dunkle (1942) and Robertøon (1943), respectively, from the Kiddle Pliocene of Kansaø, may not belong to Profundulus."

This would indicate that the genus Profundulus or, more probably, a stoek similar to It was distributed from the Mexdcan Plateau to Death Valley, at least in the middle Plocene or even earlier. This stock differentiated on the one hand into such elosely related genera as Profundulus, Bmpetrichthrs and Crenichthys and on the other Into Fundulus. From the latter were derived two stocksı Cyprinodion and 1ts allies (Group I), and the Adinia-Lucanta group. Lucania parva, Chrlopeops goodel (Lucante goode1 of several recent authors) and Leptolucanta omata are elosely related forms and it is suggested that Lucania parva, which ranges along the Atiantic Coast from Connecticut to Mezico and enters the Iresh waters of Florida, may have differentiated in Florida to form two strietly fresh water specles Chrlopeops goode1 and Leptolueania onmata.

Although the foregoing phyletic trends are suggested by the present findings, a more exchaustive study is required to determine the precise relationships of various genera in croup III. Nore information Is needed concerning the fossil record, a more thorough coverage of 
representstive species especially in the genera Fundulus and Profundwlus is necossary, and, in all the forms, more data are required on the comparative ostrology, embryology and anatony of the soft parts.

\section{Relationships of Bmpetrichthys}

Before concluding the part on the relationships of Croup III, It is worthwhile to coment separately upon the relationships of Mapetrichthys because they have been confused in the past. In his original description Gilbert (1895: 235-254) comented that Bupetrichthye "seoms most ciosely allied to Orestias, of which nunerous species have been described from Lakes in high Andes of South America." Garman (1895: 116) regarded the genus as "allied to Fundulus through the wore compressed species." Jordan and Bvermann (1896: 651, 667) placed Bimpetrichthys in the subfamily Orestilnae and Eigennann (1920) seened equally impressed by the rather close superfleial resemblance of Impetrichthys and Orestias when he commented: "They are so similar that they might be regarded as forming but one genus." Similariy Jordan (1925: 158) 11sted Empetriehthys and Orestias as the only members of the family Orestildae and thereby indicated their close relationship. Jordan, Evermann, and Clark (1930: 182) erected a separate fandly, Mmpetrichthydae, for the sole reception of Bampetrichthys. Myers (1951; 10), utillaing some of the skeletal characters (simple epipleurals and the presence of parietals in Pmpetrichthys as against bifid or trifld eptpleurals and the absence of parietals in Orestias pentlandi1) concluded thats "It [Bupetrichthys] appears to have nothing to do with Orestias." He placed [Mnpetrichthys] 
in the subfamily Fundulinee of the family Cyprinodont1dae but left untouched the precise relationships of this genus with the other genera included in the tribe Iundulint. Hubbs (1952) while eormenting upon the aame problem remarked that "There 18 probably no Imaediats relationship between Empetrlchthys and Orest1as, although both were probably derived from some such baste stock as Profunculus." Miller (1948: 100), on the other hand, remarked differently: Empetrichthrs probably originated from Frmqulus, as was suggested by Garnan."

I agree with Myers (1931) that Bmpetrichthys and Orest1as are unrelated genera, but hls use of the eplpleurals to distinguish these two is not applicable because Orest1as agassiali does not possess bifld epipleurals as described by him for 0 . pentlandi1. Moreover, Crentchthys nevadae, a elose relative of Bupetrichthys, also has a few bifld epipleurals. Therefore, the only remaining character which could be elted to differentiate Fnpetrichthys from Orestlas concerns the presence of parietals in the former and absence of these bones in the latter. However, a number of characters 1llustrate the differences between these two genera. These differences are 11sted in Table 9. 
TABLE 9

OSTEOLOGICAI, DIWWEREMGES BETWEEN BMPETRICHTHYS AMD ORESTIAS

Orestias

\section{Parietals}

Present

Vomer

Present
Absent

Absent

\section{Preopercle}

Both vertical and horlzontal portions of the preopercle elongated and pointed; a large bony landna toward 1ts anterlor and and a sensory canal toward Its posterior extremity the shape 1s like other fundulids.
Both verticel and horlzontal portions of the preopercle comparatively less elongated but rounded; a amall bony lamIne toward 1 ts anterior end and no sensory canal toward 1 ts posterior extremity; the shape is like Rivulus and other South American aplochellids.

\section{Postorb1tal}

Prominent as in Fundulus and other fundulids.
Very anall as in Rivulus and other South Anerican aplochellids.

\section{Anterolateral Processes of Iaterel Ethmolds}

Small I1ke other fundulids.

Long 11ke South American aplocheil1ds.

\section{Poster1or Kyodome}

Present

Absent 


\section{CROUP IV}

\section{Composition, Range and Habltat}

The group consists of the monotypic genus Valencia. It is the only living gems of the Old World which superflcially resembles funduIus and is represented by Valencia hispenica (Cuvier and Valenciennes) fron fresh waters of Spain. Fundulus letourneauxd (Saurage), whlch has been wentioned in the literature as a second specles of Valencia from Cortu, has been described by Myers (1958: 157) to belong to Aphenius.

\section{Osteology}

The skeletal characteristies of Valencia hispanica are very similar to those of Profundulus hildebrendl and to a lesser degree to those of Fundulus chrysotus. Because of these polnts of agreemant the osteological description of the New World fundul1d (Oroup III) Is used as a basts in the following description of Valencia hispantea, but the account gdven for Cyprinodon generally applles to this species also.

The occipital region consists of the usual four occipital bones. The supraoccipitel stops short of reaching the foramen aagnum and consequently onif the excocipitals form the sides and the roof of the foramen magnum. Both the basiocelpital and the exocelpital condyles are prominently developed and through then the skull articulates with the first vertebra. The neural arches of the flrst vertebra are separate from the occipital reglon of the skull. 
The entire ethmoid region, including the mesethmold composed of double ossifled laninae, lateral ethmolds and vomor, is much like that of Profundulus. The nasals are almost roumd and have their anterLor extremities dram forvard to a noticeable degree.

The palatoquadrate bar of the mandibular arch has both quadrate and autopalatine ossifications. The entopterygold is applled to quadrate and autopalatine bones from behind. The metapterygold is absent.

Both the outer and Inner processes of the madlla are well developed. The mesial process of the maxdlla 1s, however, more elongated than the New World fundultde. The premaxdilary processes are broad and elongated.

In the lower jaw, articular, angular, sesamoid artieular and dentary bones are present as in the other cyprinodonts.

Both the premaxdila and the dentary bear conleal toeth. The outermost row of teeth 1s longer than the Imner teeth which are arranged in a band.

The hyold arch consists of the hyomandibular and the symplectic as in other eyprinodonts.

The hyold cornu is normally disposed and consists of the usual bony elements. The hyopohyel is represented by a single plece on each side.

Six branchfostegal rays are present on each side. 
In the otic region, the pteroties slope gradually toward the lateral corners of the akull as in Produndulus but oplotile processes are lacking. As in other cyprinodonts, an opisthotic is absent.

There are distinct parletals in the orbitotemporal region of the skull and the supraorbital processes of the frontels are well developed. A wide notch 18 present between the posterlor edge of the supraorbital process and the sphenotic process to accommodate the well-developed postorbital. Compared to Profunculus and other llew World fundulids, the preorbital in Valeneia hispanica is narrow but It is not as narrow as in the aplochellids (Group V). In this connection It 18 appropriate to note that the preorbital is also narrover In Aphanius, Anatolichthys and Kosswiglehthys than in the New World cyprinodontids related to Gyprinodon. The dorsolateral processes of the parasphenoid extend laterally to come in contact with the allsphenolds and thereby enclose a wide modione as in Bnpetrichthys, Pundulus eingulatus and Fundulus kansae. An antorovestal process of the protolo is lacking and, therefore, this bone takes no share in the formation of the posterlor myodame. As in other eyprinodonts, the bast sphenold is absent.

The branchial akeleton consists of IIve gall arches with the fifth one modifled into the lower pharyngeals. There are twelve gillrakers in Valencia hispanice and most of them are ahaped 11ke a rosette. The third hypohyrals bear a sonall patch of confeal teeth and a sindlar but larger patch extends laterally along the fourth ceratobranchials up to hale their length. 
The basihyal and the urohyal are normaly disposed and there are only two ossifled basibranchlals.

Four eptbranchials are present as in other cyprinodonts. The first pharymgobranchial is cart1laginous but the other three are separate and bear conleal teeth.

The lower pharymgeals are of normal shape and their anterlor extremities come in close contact with the fourth ceratobranchials.

The posttexporal is uniorked.

\section{Summary of Slgniflcant Osteological Characters of Group IV}

The summary of the osteologlcal charactors given for the llew World fundulids (Oroup III) w111 apply equally to Valenc1a with the following modifleations:

\section{Otic Region}

(1) No posteriorly directed otic processes. Orbitotemporal Region

(2) Preorbital rather narrow in comparison to those of New World $f$ uncullds.

(5) Poaterior myodone aimilar to Empetrichthys, Fundulus cinguratus and Fundulus kansae.

Other Characters

(4) Third and fourth phaxymgobranchials separate as in Profunduius hildebrandi. In this respect both Valencla and Profundulus agree with aplochellids and differ from other New World fundullds. 
(5) Modian hypural is diflded into two equal parts by a median slit.

(6) Neural arches of the N1rst vertebra separate from the oceipital region and do not meet above the neural canal to form a neural spine. A bony septum, as in Profunculus, connects the neural arches a little below their distal extremities.

(7) Branchlostegals six.

\section{Relationships of Valencia hispanica} (Group IV) .

Myers (1951; 249-250) Indicated the elose relationship of Valencia and the New World Iundulids (Group III) by Including both In the tribe Funduilint. Further, he (10c. e1t.) coanented on Valeneia, which has a narrow preorbital: "... this genus may represent the ancestral stock from which the Rivulind have aprung." Kosswlgichthys, due to 1 ts conical teeth, was thought to be related to Velencia and the New World fundullds. However, as has already been polnted out, experimentel hybridization and cytologleal studies by Aksiray (1952) and Oztan (1954) demonstrate that Kosswiglehthys actually is related to Aphanius and Anatolichthys. My study has produced osteological evidence in support of this latter conclusion. Hoedeman and Bronner (1951) erected the tribe Profundulidi to Incinde Profundulus and and Adinia of Now World and Valenela and Kosswlglehthys of Old World, but Miller (1955: 10-21) regarded this arrangenent as unnatural and suggested 1ts abandoment. Steinitz (1951; 121) regarded Valencla 
as a relatively old and generalized type in contrast to the more recently evolved and highly speclalized Kosswiglehthys. Miller (1955: 11) wrote about Valencias "An excamination of specimens of Valencia hispenica and of syntypes of V. letournourd convinces mo that this genus is a generalized, independent derivative probably not closely related to any New World genus."

Nyers (1928) established the genus Velencia, formerly included In Fundulus to reeeive the only Old World Pundulus-like spectes FunduIus hispanica from Spain. As mentioned previously, another species Fondulus letourneauxd from Corfu, whlch is mentioned in the literature as a aecond spectes of Valencia, is according to Myers (1958) an Aphantus. Because Maller (1955) recently referred to this species as Valencis letourneawd further study is needed to elarify its relationships, Myers (1928) in describing Veleneia, mentioned that the absence of a genital pouch was the only important diagnostle feature In which this genus differed from the New World fundul1ds. But the genital pouch is also absent in Bimpetrichthys and Crentchthys and 18 very weak in Profundulus.

My study shows that the osteology of Valenela hispanica is very similar to that of the New World fundullds. Except for the preorbital, which is comparatively narrow in Valencia, there are no osteom logleal characters which are not found in the New World rundurlds. It 1s pertinent to point out here that the preorbital is also narrow in 
Empetrichthys and Crentchthys. In Pact no osteological character has been found which would distinguish Valencia from the Now World Sundulids.

In spite of this close resemblance of Valencia to the New World fundulids, relative to both 1ts ostrological and other features, it has been auggested by Myers (1938) and by Muller (1955) that 1t 18 not phylogenetically close to the New World fundulids. Valencis, therefore, needs further study to elarisy 1 ts correct relationships.

In the absence of any detalled morphological information about Velencia and Profundulus, both of which have been shown to be generalIzed primitive types, the only other information which might throw eome light on their relationships is their exclusive oecurrence in fresh water. Whether this has been always the case is not elear.

It is possible that some widespread ancestral stock structurally resembling the widely distributed aplochellids of today entered the Presh waters of Central America and Spain to later produce ProfunduIus and Valencia respectively. 


\section{GROUP V \\ Composition, Range and Habitat}

The group is almost world-wide in distribution and Includes the largest number of species of oriparous eyprinodonts. Its mambers range throughout most of tropical Americe from Santo Domingo and southern Mexico to Columbia and La Plata, Ethioplan and Mile regions of Africa, Nadagasear, the Seycholles and In Asta from Malabar to Siam on the mainland and southward to Bormeo in the Bast Indes.

The following geners are Includeds

Tropical America

Rivulus Poey. Over thirty-seven species are known. Range: Mexdeo, Central America, Antillean Islands, South America (Irom Colombia to La Plata). Harrington and Rivas (1958) have roportod a species, Rivulus mermoratus from Florida (Indian River and Biscayne Bay).

Habitat, fresh, brackish and marine littoral waters. Rachovia Lyers. Two species.

Range: Colombia.

Habitate ponds and madholes which dry up once a year. 
Pterolebias Garman. Two species.

Range: Orinoco River Basin, Venezuela; Sentarem on the Lower Amazon, Brazill; and Peruvian Amazon.

Habitat: Iresh water.

Cynolebias Steindechner.

Range: Eastern South Americe Prom Buenos Alres to northesstern Brazil.

Habitat: ponds and mudholes which dry up onee a year. Rivuliehthys Myers. Monotypic.

Ranges upper Paraguay and Amagonian tributarles of Matto Grosso in Brazil.

Habitat: freah water.

Neorundulus Myers. Monotypic.

Ranget reported from Aroyo Trementina, Paraguay and a clay plt on the east bank of the RIo Cuyaba at Parl, six las. from the torm of Cuyaba, Matto Grosso, Brasil.

Habitat: freah wator.

Austrofundulus Myers. Three species.

Range: Venesuela.

Habitat: ponds and pools which dry up once a year. Trigoneotes Myers. Monotypic.

Range: reported from Porto lacional, Rio Toeantins, Boyas, Brazil.

Habitat: freah water. 
Hubbsichthys Sehultz. Monotyple.

Range: reported from Pampan, Estado de Iraj110,

Vonezuela and possibly in Rlo llotatan drainage. Africa, Madagasear and the Seychelles

Aphyosemion Myers. About thirty-seven species.

Ranger coastal region of West Africa (Iiberia, Gold

Coast, southern MIgeria, Cameroons, Caboon and over the entire Congo Basin).

Habitats fresh and bracklah wators Including pools and madholes which dry up once a year.

Nothobranchivs Peters. About thirteen species.

Ranget Somalliand and Mozambique to the Central African Lakes and northern Migeria. It is not found in the Congo Basin or the West African rain-forest where Aphyosention oceurs.

Habitat: frosh and brackish waters including pools and mudholes which dry up once a year.

Pachypanehax Yyers. Three species (Kyers, 1933: 182).

Range: Seychelles Islands and Madagasear.

Epiplatys all. Nore than twenty-five species.

Range: Afrlea except the eastern part.

Habitats fresh and bracklsh waters.

Asta

Aploche1lus MoClelland. About seven species.

Range: India, Burna, Malay Peninsula, Slam and IndoAustrallan Arehipelago.

Habitat, freah, bracidsh and marine littoral waters. 


\section{Osteology}

The account is based on a study of seven specles representing six of the fourteen currently recognized genera comprising the group. Several genera (Rivulichthys, Neorundulus, Hubbsichthys), known oniy Prom one or two specimens and collected but once, need reinvestigation based on more representative material to establish their separate valldity (Hyers, 1927, 1942; Shultz, 1949). The spectes which have beon studled ares Rivulus bondi Schults, Cymoleblas whitel Myers, Austrofundulus stagnalis Schults, Aphyosemion australe (Rachow), Aphyosention caeruleum (Boulenger), Nothobranchius taenopygus (Fillgendorf) and Aplochellus penchax (Hamdlton Buchanan).

The head akeleton of Aplochellus lineatus has been deseribed by Ramaswanl (1946) and Kulkarn1 (1948). Their papers include port1nent detalls of the osteology of the genus Aplocheilus.

The osteological characteristics of the specles strudied are very alindlar' and, therefore, the following description will apply equally to all of them.

In all the geners of Group $V$ included in this study (M1gs. 45, 46 and 49), the skull 18 characteristically nat and depressed. Moreover, the postorbital reglon of the skull, behind the laterally projecting sphenotic processes is verg broad. The skull may be deseribed under the usral four hoadingst the ethmold region, the orbitotemporal region, the otic region and the occipital region. 
Ethmold region

The ethmoid region differs markedly from that of the cyprinodonts in Croups I, II, IV, VI and VII, In that an ossifled meaethmold is absent. Instead, as in Croups II and VI (presently to be described), the mesethmold in the nembers of Croup $V$ is a amall, median heart-shaped eartliage, situated in the anterior depression of the ethmold reglon. Thls cartilaginous mesethmold is broad in front and narrov behind. The posterlor extreulties of the premadllary processes rest on this cart1lage and are closely attached to it by muscular t1saue. The cartilaginous mesethnoid is also in close contact with the maxillae and the rostropalatine processes of the autopalatines of both the sides. The mesethmold slides backward and forward with the movement of the premadilary processes and, consequently, its attachnent with adjacent bones helps to coordinate the movements of the Jaws. A aintlar situation has been deacribed in Aplochedlus IIneatus by Kulkarnt (1948). Except for Aplochellus In which the anterolateral processes of the lateral ethmolds are small, all the other genere under consideration posess long and well-developed anterolsteral processes. The vomer 18 a proninent median bone atteched by Its attemuted posterior end to the ventral surface of the paresphenoid. The mediolateral edges of the voner are dram out and come in contact with the lateral ethnolds from below. The anterior end of the vomer is pointed and provided with a patch of conical toeth (FIgs, 46 and 49A). The paired nasals are small and imrogularly shaped. 
Orbitotamporal region

The orbitotemporal reglon is well developed and generally resembles that of Fundulus and Its allies (Group III). The parletals, however, are variable in the genera under consideration (Group V). The parletals are absent in Nothobranch1us; ebsent or fased with the posterior edges of the frontals in Austrofundulus, Aphyosention; small in Cynolebias; and well developed in Rivulus and Aplocheilus. The frontals are well developed and extend considerably forward over the ethroid region. The supraorbital proeesses of the frontals are extensive and cover the eyes completely. In the posterior orbital reglon, each supraorbital process of the frontal has a wide notch for the reception of the postorbital. In Aplochellus the postorbital is a volldeveloped, boat-shaped bone with an open groove for the lateral IIne sensory canal toward 1ts outer surface. The postorbltal, however, is very small and Inconspicuous in all the other genere under consideration. The interorbital area of the frontals is rectangular. The lachrymal is characteristically tolisted with 1to upper and analler portion direeted anterlorly and horizontally while 1ts lower, comparatively longer $11 \mathrm{mb}$ is vertically disposed. A vertical median grcive runs the antire length of the lachrymal. This is termed an aplochellid type of lachrymal which is characteristice of Croup V. The paraephenold 1s prominently located on the ventral side of the skull. It 1s, in comparison to that of other cyprinodonts, a wide bone and extends considerably forward in the ethmold reglon. Except in RIvulus where the anterolateral processes of the parasphenold extend laterally 
to meet the alisphenolds and thereby enclose posterlor myodomes on both sides, the enterolateral processes in all the other genere are amall and do not meet the allsphenolds. Consequently, posterlor myodomes are absent in all these genera.

\section{Otic region}

The otic region is similar to that of other eyprinodonts except that the laterally projecting sphenotic processes are broader at their extremities. The epiotic procesees and the opisthotics are absent.

Oecipital region

The oceipital region is composed of the usual four bones, the supraocelpital; the basioceipital and the two exocelpitals. The exoccipitals complete the roof and the side walls of the foramen magnum while the floor of the latter structure is formed by the basiocelpital. The supraoceipital stops short of resching the foramen magnum and, therefore, takes no part in Its formation. Both the basioccipitel and the exoceipitals bear prominent condyles for articulation with the first vertebra. The neural arches of the first vertebra are separate Prom the oceipital reglon and take no part in the articulation. The Pirst vertobra has a distinct neural spine and also possesses corresponding facets towards 1 ts anterior and for articulation with the skwll. 
Visceral skeleton

The pelatoquadrate bar of the mandibular arch in these $a 1 x$ genera of eyprinodonts is unique in possessing an additional bony element, the metapterygo1d (F1gs. 47A, 50A, and 57A). Starks (1904), Regan (1911), and Myers (1951), in listing the distinguiahing characters of the auborder Poecilioldea of the family Cyrpinodontidae stated that the metapterygoid is absent in the group. However, the metapterygoid is present in 1te normal position in each of the seven apecies exantined in this study (Rivulus bondi, Cymolebias whitel, Austrofundulus stagnalis, Aphyosention australe, Aphyosemion caeruleum, Nothobranchius taeniopysus and Aplochellus panchax). It is well ossified and Its relationship with the hyomandibular, symplectie, quadrate and mesopterygoid confirms 1ts 1dent1ty. Moreover, it agrees in Its position and shape with a similar bone in the Haplomous f1sh Novumbra hubbs1 (Chapman, 1934). Sim1larly Ramaswami (1946) and Kulkamp (1948) found th1s bone in Aplochellus Iineatus. Kulkarnl (op. c1t.) also mentloned Its presence in one additional species, Aplocheilus blochil (A. parvua of Sundre Raj, 1916) and A. panchax, a species which is Inciuded in this study. Kulkarns (op. c1t.), therefore, pointed out the necessity for a reviston of the present distingulshing characters of the suborder Poecllioldea. The presence of a distinct metepterygold in so many different genera, as revealed in this study, confirms the need for such a reappralas. The metapterygoid in all these species Iles above the aymplectic with 
which it is elosely associated posteriorly it extends underneath the membranous portion of the hyomandibulary anterlorly it comes in contact with the meapterygold and the quadrate. Except for Cynolebias in which this bone is splint-1ike, it is quite prominent in all the other geners. The symplectic is large and prominent. The hyomandibular, the quadrate, the autopalatine and the mesopterygold are normally disposed. The rostropalatine process of the autopelatine 18 long, extends forvard, and 18 well separated from the ethnopelatine process of the same bone. The premexdllae bear small but unifornly broad premadillary processes which extend to the dorsal surface of the cartilaginous mesethmoid (M1gs. $48 \mathrm{C}$ and 51C).

The maxillae are similar to those in Fundulus and 1ts allies (Group III). The much elongated masial processes of the madllae are disposed horisontally instead of more or less anterlorly as in pundulus and Its allied (Fig. 5OB). Each premaxdila is provided with conteal toeth arranged in a band.

The mandibular bar of the palatoquadrate areh is like that of other eyprinodonts in number and arranganaents of 1ts bony elements and the dentarles bear teeth similar to the premadillarles.

The usual four opereular bones are present but the preopercle 1s of norwal shape only in Aplocheilus. In the other genera under consideration It differs in that both the upper vertical and the lower horizontal portions are broad. This broadness is particularly pronounced in the lower portion which falls to extend forward under the 
quadrate in the customary manner. Moreover, in all the geners except Aplochellus, the membranous expansion between the two limbs of the preoperele is less extensive than is usual in cyprinodonts.

Branchlal arches (M8. 48B)

There are five branchial arches and each is composed of two laterel halves containing the same number of bony elensents as in other cyprinodonts. There are, however, three ossifled besibranchials similar to those of Oryelas (Group VII). This is in contrast to only two of these elements in all the other cyprinodonts included in this stucty. The additional plece lies immediately posterior to the basihyal and 18 smaller than the other two basibranchials. Except for Oryzlas latipes, such an ossifled basibranchial is not present in the other cyprinodonts examined during the course of this study. In these latter cyprinodonts the f1rst and the fourth bastbranchlals remaln unossifled while in the group under discussion and Oryzias (Group VII) only the fourth basibranchtal is unossifled and there are three ossifled bastbranchials. Three ossifled and the fourth unosBLfled basibranchials have also been described in Aplocheilus Iineatus and Oryzias melastigna by Rulkarnd (1948).

The eplbranchials, pharyngobranchials and ceratobranchials are normally disposed. Unlike other oyprinodonts, except Profundulus and Valencia, the third and fourth pharyngobranchials are separate and do not fuse to form a aingle plate. 
Hroid arch

The dorsal portion of the hyold arch includes the hyomandibular and the symplectic. The hycmandibular has a quadrilateral shape in contrast to the elongate one nornal to other cyprinodonts.

The hyold cormu is sinllar to that of other eyprinodonts except for the hypohyals which are represented by two pieces on both sides. There are six branchlostegals in all the seven specles included In the present study. The branchlostegals are arranged in two groups-the first contains two rays and the second has four. Two of the outermost rays are broader than the others. The basihyal and the urohyal are normally disposed.

In Aplocheilus the posttemporal is unforked; in Austrofundulus, Cynoleblas, and Nothobranchtus, it is unforked, but towards its base a portion of the IIganent comnecting it to the excocelpital may be ossifled; In Rivulus and Afhyosemion (both specles) it appears to be forked because the ligament to the exoceipltal is ossified for about hale its length ( $\mathrm{Fgs} .48 \mathrm{~A}, 51 \mathrm{~B}, 56 \mathrm{D}$ and $57 \mathrm{~B}$ ). 
Sunmary of Significant Ostoological Characters of Group V

\section{Ithmo1d Region}

(1) Yesethmoid cartilaginous.

(2) Vomer dentigerous.

\section{Orbitotemporel Region}

(3) Parletals variablas well developed in Rivulus bonds, Aploche1lus panchax, Aplochollue Iineatus (Kulkams, 1948), small in Cynolobles whitel, Ineonspicuous in Austrofundulus stagnalis, Aphyosemion australe, Aphyosemion caeruloum; and absent in Nothobranchlus taen 10prous.

(4) Anterolateral processes of the parasphenold variables In Rivulus they are long and extand laterally to meet allsphenoids and thereby enclose posterlor myodomes on elther side; in all other forms studied, no posterlor yodome is forrued because these processes do not meet the altsphenoids.

(5) Interorbital area rectangular; supraorbital processes of the frontals well developed and cover the eyes completely.

(6) Foranen magnum formed by the baslocelpital and exocelp1tals; supraocelpital stops short of reaching the foramen and therefore takes no part in Its formation. 
(7) Both the bastoccipdtal and exoceipitals bear condyles for artieuation with the first vertebra.

(8) The transverse processes of the first vertebre meet dorsally to form a distinct neural spine and take no part in the articulation.

Otic Region

(9) No oplotic prooesses.

\section{Visceral Skeleton}

(10) Metapterygold present.

(II) Teeth conicel and arranged in a band.

(12) Premaxillary processes mall, uniformly broed and extending over the mesial processes of the maxdllae to come in contact with the mesethmold cartilage.

(18) Upper portion of the mexdlla with well-developed mesial and less well-developed outer processes.

(14) Hypohyals on each side represented by two boxy pleces.

(15) Six branchlostegals arranged in two groups--flrst group with two rays and the second group with four.

(16) Third and fourth pharyngobranchials separate.

(17) Three basibranchtals.

\section{Other Reglons}

(18) Posttemporal Elightly forked to unforked: forked to half Its extent in Rivulus bondi and Aphyosemion (both species); unforked but with a portion of the ligament connecting It to the exoccipital ossleled towards the base in 
Austrofundulus, Cymolobias and Nothobranchius;

distinetly unforked in Aplocheilus.

(19) Transverse processes of the precaudal vertebrae elongate.

(20) Subcleithral bone present in Rivulus, Austrofundulus and Cymoleblas (New World aplocheilids); absent in

Aphrosemion (both spec1es) and Aplochellus.

(21) Wide haemal canals in Aplochellus; not so wide in the other genere.

(22) Prezygapophyses prominent and meet dorsally to enclose canals.

(25) Fypural trifld in Aplochellus panchax, bifid in the other spec1ea (FIg. 58). 


\section{Relationships of Group V}

These widely separated genera of eyprinodonts agree rather elosely In their osteologleal characters. All of then posaess a metapterygoid, three ossifled basibranchiels, an enlarged dentigerous vomer, a hypohyal on each side represented by two bony pleces, separate third and fourth pharyngobranchials, prominont prezsgapophyses which moet dorsally to snclose canals, and a bleld or trifld bypural. On the basls of these characteristies, the group appears to be a vell-defined assemblage of genere desplte the variation noted relative to the posttemporals and the parietals. Taken collectively, these characteristics, Including those which show varlation, indieate that the aplocheilids are more generallzed than any other taxon in the order eyprinodontiformes. The skeletal elements of aplochellids appear to form a foundation material which, by either loss or modifleation, has evolved into characteristics of the other groups within this order. The present high degree of diversity within the aplochellids, however, suggests an ancient lineage and the possibility that a once widespread ancestral stock sindlar to them produced not only the aplochollids but also other groups as well.

In the possession of a watapterygoid this group shows agreement with the famsly Amblyopsidae, suborder Amblyopsolcea. Hitherto, following Rogan (1911), It has been supposed that the motapterygold was absent in the suborder Poec1lioidea to which all the cyprinodonts except amblyopsids belong. It is entirely possible that the amblyopsids, as well as other groups of eyprinodonts ovolved from 
aplochilid-11ke ancestors, when the latter were nore videspread. The present distribution of the amblyopsids, restrieted as they are to the swemps, caves and springs of the southeastern and central Untted Statea lends additional cupport to this vlew (Woods and Inger, 1957).

The Aploche1I1ds show relationshipe with both the pecullarly organised genus Orestias, fros the high Andes of Peru, and the funduIIds of North America. They seem to be related to Orestias in the possession of lateral ethmolds with well-developed anterolateral processes, prominent prosygapophyses meeting dorsally to enclose canals, amall postorbltal, pharyngeal teeth with a alight shoulder as in Rivilus and the shape of the preopercle which in Orestias is more 1ike that of the South Amerieen aplochell1ds. The detalls of this relationship are discussed in comnection with the genus Orestias.

In the possession of the parletals, the exoecipital contyles, the formation of the foramen magnum by the baslocelpital and exocelp1tals, the nature of the upper portion of the mardila, and the nature of the transveree processes, the aplochellids seem to be related to the fundulids. Ther are more closely rolated to Profundulns, jupetrlchthys and Crenichtbys in eertain other characters which have already been deacribed in comnection with the three latter genera.

The aplocheilida show relationships to the aphanids as well so aplochellichthyiens (Including Lamprichthys) in possessing a cartilagInous nesethnoid, the nature of the oceipital region with well-devaloped 
exocelpital condyles. They, however, seem to be more elosely related to the ploche1lid thylans in the nature of the premadilary processes, -longated transverse processes, prominent prezygapophyses meeting dorsally to enclose canals and the close simflarlty of the pectoral girdles of Aplocheilus and the plocheilichthylans.

The aplochellids are related to Valenela in the sane characters as they are to the North American Pundulids.

The aplocheilids also show afrinity with the peculiax Asiatle genus Oryzias in possessing well-developed exoccipital condyles, in the nature of the prenerdillary processes, in the twisted and narrow character of the preorbital, in possessing three osslfled baglbranch1218 , in the bifld hypural and in the close resemblance between the pectoral girdles of Aplocheilus and Oryzlas.

It seens probable that the aplochellids gave rise to all those groups with which they show relationship. The restrieted distribution of the groups which were derived from the aplochellids in different parts of the world and the world-ulde distribution of the aplochellids seem to support this conclusion. Moreover, as has already been pointed out, they possess certain generallzed characters whloh were either dropped or modirled in the other groups. The aploche1l1ds, therefore, may well be considered a basle group from whlch varlous other groups of eyprinodonts have evolved. 
CROUP VI

Conposition and Range

The nembers of this group are conflned to the Ethioplan and the Klle regions of Africa. The folloulng genere are included:

Proeatopus Boulenger. Four species.

Range: confined to the Cameroons.

Hypsopanchax Myers. Three species.

Range: confined to Central Africa (the Congo, the Ogowe river systems and the Lake Idward area.)

Platypanchax Ahl. Monotypic. Differs from Ilypsopenchax only In dentition.

Aplochellichthys Bleeker. Thirty-elght deserlbed Iorms, none are perhape not valid and many good spectes st111 remain undiscovered (Nyers, 1958: 142).

Range: Irow Mile and Cuinea south to Angols and Zululand. Meropanchax Myers. For certain species of Aplochellichthys. Later amalgamated by Myers (1938) with Aplochellichthys, but again revived by Schultz (1942). B. Irewavas, of the Brit1ah Huseum, also considers It to be a valid genus (personal communication). Cymopanchar Ahl. Monotypic.

Ranges Bukobe, N.W. Tanganylka Terrltory. 
Plataplochellus Ahl. Monotyple.

Ranges "Attogondema, Nga R., Cemeroon." (Nyers, 1958: 145). Lamperlohthys Regan. Monotypic.

Range: Lake Tengangika.

\section{0stoology (Figs. 54 and 55)}

This account is based on a stuct of four species representing two of the seven genera comprialng the group. The three genera deseribed by Ahl (1928) mainly on the basis of teeth may not be tenable on further study as has been pointed out by Myers (1938b). The apecies which have been studied ares

Aplochellichthys johnstonl1 (Gunther), A. katangae (Boulenger), Micropenchax loat1 (Boulenger), and ‥ schoellery (Boulengar).

The osteologieal eharacteristics of these four specles are very similar and, therefore, the following description will apply equally woll to all of them. In ell the four specles the skull is nat and uniformly broad behind the postorbital and the orbital regions.

The ethroold region conslsts of the nasals which are roughly triangular in shape and almost round on their posterior edges. The lateral ethnoids are prominent but the vomer is small and w1thout teeth. The mesethmold is eartilaginous.

The orbitotemporal region lacks parietals on the dorsal alde. The Prontals are well developed and their supraorbital processes are extensive. There is a wide notch behind the supraorbital process and the sphenotic bone. Both the postorbital and the lachrymal are well 
developed. The parasphenold is norrally located on the ventral side. The inner processes of the parasphenold are amell and fafl to meet the alsphenolds and, consequently, the posterlor modome is absent. The otic bones are loeated as in other eyprinodonts and the oplsthotic is absent. A prominent cartilaginous area is present on both sides between the ot1c bones and the frontal.

The ocelpital region consists of the uswal four oecipital bones. The exoccipitals bear prominent exocelpital condyles and form the sides and roof of the foramen magmum. The supraocelpltal stops ahort of reaching the latter strueture. The basloecipital bears a prominent basloceipital condyle and is located on the ventral side of the skull.

The pelatoquadrate bar of the mandibular arch shows two oss1Plcations, the quadrate and the autopelatine. The metapterygoid is absent. The mesopterggold 18 applied to the quadrate and the autopelatine from behind.

The mandibular portion of the nandibular areh contalns an articular bone in the lower jaw and a amall plece of the Meckel's cartillage which persists in the adults. The dentary and the angular are present in their normel positions.

The upper Jaw consists of paired maxdilae and the premerdilae. The premexdllary processes are broed as in aplochellids. These processes are clove together and are connected to the cartilaginous mosethmold. In Meropanchax 20at1, both the outer and the mesial. processes of the mardlls are well developed but in the other three 
species the outer process of the maxilla is better developed than the mestal process. The maxillae are edentulous while both the premardilas and the dentarles are provlded with varlable rows of confeal teeth. The outermost row in all of them consists of comparatively larger teeth. There are four rows of teeth in Aplochellichthrs katangae, three rows in A. johnstont1 and Mieropanchax schoollerl, and two rows in 프. 10at1. The hyomandibular, the symplectic and the hyold cornu are 10cated in their norwal position. The hypohyal on each alde is represented by a single plece and both the urch yal and the besthyel are normally positioned.

In both species of Aplochelliohthys under discusaion, there are Iive branchlostegal rags-cthe IIrst group has ons ray and the second group has four. In the two species of Micropanchax there are, however, four branchiostegal rays--none in the PIrst group and four in the second. The branchial skeleton 18 sillilar to that of other eyprinodonts. There are five gill-arehes consisting of the usual segments and showing similar modiflcations. The four epibranchials are similar In structure. The first pharyngobranchial is cartilaginous, the second Is a separate ossified piece with conical teeth, the third and the fourth are fused to form a single ossifled plate with confeal teath. There are nine gill-rakers in Mleropanchax loat1, ten in M. sohoeller1, and eight in Aplochoilichthrs katangae. The gillrakers were not counted in $\mathrm{A}$. johnstonif.

The opercle bones are normal in all four species. The posttemporal is unforked and there are two ossifled basibranch1als. 
Sumeary of Signifleant Osteological Characters

of Group VI

\section{Bthmold Region}

(1) Mesethmold cartilaginous.

(2) Vomer edentulous.

Orbitotemporal Reglon

(3) Parletals absent.

(4) Posterlor yyodome absent.

(5) Anterolateral processes of the parasphenold mall and not meeting the ellsphenolds.

(6) Postorbital and preorbital (lachrymal) well developed. Oecipital Region

(7) Foramen magnum formed by the basloecipltal and exoceipitals.

(8) Supraoccipltal not reachlng foranen magmum and, therefore, does not share in its formation.

(9) Both the basioccipital and exocolpital condyles well developed.

(10) Artieulation between the skull and Nirst vertebra through the condyles.

(11) First vertebre with distinct neural spine; noural arches separate from the occipital reglon.

Viaceral Skeleton

(12) Metapterygold absent.

(13) Teeth confeal and arranged in two to four rows in the species under consideration. 
(14) Premaxdllary proeesses small and broad.

(15) In Mlcropanchax loat1, both mestal and outer processes of upper portion of maxdlla well developed; in the other three species only the outer processes of the maxdilae well developed.

(16) Hypohyal on each side represented by a single plece.

(17) Branchiostegals five in Aplochellichthys and four in Mieropanchax.

(18) Third and fourth pharyngobranchials fused.

(19) Two ossifled bastbrenchials.

Other Reglons

(20) Posttemporal unforked.

(21) Transverse processes of precaudal vertebrae elongated.

(22) Prezygapophyses elongated and joined dorsally to enclose canals.

(23) Pelvle Pin rays elongated.

(24) Space between the coracold and the ellethrum of pectoral girdle very prominent.

(25) Peetoral IIns high set.

(26) Median hypural a single fan-shaped piece. 


\section{Relationships of Croup VI}

The genera comprising Group $\mathbf{V}$ form a elosely interrelated and homogeneous unit. Their chlef diagnostic feature relates to the high position of the pectorals the upper ends of the bases of these fins are located above the midnine of the body. Th1s character alone sets then apart from other African eyprinodonts except for Lamprichthye tanganicanus. Thts species approaches the aplocheilichthylans in the position of the pectorals and is similar to thom in wany other osteological characters. Therefore, Lamorichthys tanganicanus, should not be separated from the members of Croup $\mathrm{VI}$ as has been done in the past. Lyers (1981, 21) exected a separate subfandly for the sole reception of Iamprichthys tanganicanus, although he realized that in this specles "whe pectoral flns are set high, posstbly Indicet'ag relationship to the Aplochellichthylnt." The osteological charactors mentioned by hIm for the subfandly Laxprichthyint are untenable on the basis of this study. Contrary to his deseription, both the bas1sphenold and the parletels are absent in Lamprichthys tanganicanus.

Again, while deseribing the osteologieal and other characters of the subfamtly Lamprichthylnt Hyers (1936) 11sted additional eheracters whlch he thought vere pecullar to this subfamily. These charseters are: numerous vertebrae, etenold scales, closely scaled lunate caudal IIn, connected pelvic fins inserted very nearly under the pectorals, anal IIn very long, compressed atherinid-1ike form and silvery eolor. 
Wang of the above mentioned characters are also shared by aplocheilichthylans. For example, the number of vertebras in Procatopus is mumerous, 29 or 80 (14yers, 1938, 140), although not as numerous as in Lamprichthys tanganicanus which has 41 vertebrae (Myers, 1951: 21, and my own count). The caudel $\mathrm{fin}$, although subtruncate in Procatopus nototaenfa Boulenger (one specimen exremined through the courteey of Dr. James Bohlke, ANSP 66832), Is sealed almost to the same extent as in Lamprichthys tanganicanus. Noreover, In P. nototrenia as in L. tangenicanus, the pelvio fins are long, pointed, their bases cont1guous and comnected by a nembrane, and they are distinetiy situated under the pectoral base. The anal fIn is long In Procatopus and has 13 to 17 rays; in Hypoopanchax the number of anal reys is 14 to 22 (Nyers, 2938: 140). The body is epompressed in almost all the members of aplochellichthylans but it is strongly compressed in Cynopanchax, Procatopus, Platypanchax and Hypsopanchax (Hyers, 10c. elt.). About Eypsopenehax Hyers (100. eit.) wrote: "The very compressed body, the deep, Rlattaned and sharp abdominal edge, and the shallow caudal pedunole distinguish th1s peculiar genus from Aploche1l1chthrs."

Thus It is difficult to justify the erection of a separate subfamdly for the sole reception of Lamprichthys tanganicanus chierly on the basis of Its otenold scales and Its numbrous vertebrae, for such a treatment ignores the overwhelming mintlarities which this species seems to share with such aplochellichthyians as Procatopus, 
Hypsopenchax, and Platypanchax, which should not be separated from 1 t. Noreover, the ostoologieal characteristice of aplochoilichthylans which have been included in this study and Lamprichthys tanganicanus are so similar as to offset the difforeness in the number of vertobrae and the nature of the scales.

Another point of agreement between Procatopus and Lamprichthys which Hyers (1936 and 1958) also deser1bed but whose signifleance he apparentiy falled to appreciate is the similarity of the nature of their haemal arches. Four of the haemal arches in Procatopus (Hyers, 1938) and 12 in Lamprichthys tanganicamus (m observations) are expanded for the reception of the posterlor and of the large air-bladder.

The varlous genera of aplochellichthylens have been delimited Into two groups by lyers (1958, 139) ahlefly on the basls of differences in the branchiostegal rays and the position of the pelvic PIns. These two groups are differentiated thus:

"1a. One or two of the branchlostegal rays of each s1de detached from the reat and projecting backward some distance from beneath the lower part of the opercle as a pointed process; pelvie IIns placed anteriorly, under or almost under the base of the pectoral IIns; . . 1. Procatopus Bowlenger.

1b. None of the branchlostegal reys detached and projecting beckward from beneath the opercley origin of pelvle fins behind the base of the pectorals...." All the remalning genera are Iisted under this group.

The single branchiostegal ray of flrst group, on each side, Is also detached in lamprlehthys tanganicanus and projects backward 
beneath the opercle, this indieating elose relationship of this species with Procatopus.

Therefore, because of the elose relationship of aplochellichthylans and Lamprichthys tanganicanus, I am suggesting that a single fantly Aplochellichyldae be recognized to include not only all the genera currentiy placed in the tribe Aplocheilichthyini (Hyers, 1951) but also the genus Lamprichthys. The chief diagnostic oharacters of the family Aplochellichthyldae would be: high set pectoral fins, upper and of the fin base above the midline of the depth of the body at that point; wide proorbital, usually half the eye diameter or more; body rather deep and compressed; dorsal fin orlgin behind that of anal in all currently known Sorms; metapterygoid, vomerine teeth and pseudobranchlse absent.

The aplocheilichthylans and Lamprlchthys tanganleanus show relationship to the widely distributed eplochellide in the following characters:

(1) Cartilaginous mesethmoid.

(2) Foramen magnum formed by the basioceipital and excecipitals.

(8) Supraoceipital stops short of reaching the foramen magmm and, therefore, takes no part in its formation.

(4) Both besioceipital and excoceipital condyles well developed.

(5) Firgt vertabre with a distinet neural spine and with facets for the exoccipltal enciyles. 
(6) Prezygapophyses prominent and joined to anclose canels.

(7) Close resemblance of the pectoral girdles in Aplochedlus and such genera as Aplochellichthys, Micropanchax and Lamprichthys. The pectoral girdle in all of tham has a large space between the coracold and the cleithrum.

(8) Skull rlat and depressed.

The aplochellichthylans also show agreement with the aphanids (Group II) in possessing characters one through four, but these sindlarities may be due to parallel evolution rather than to any phyletic relationship.

The family Aplocheiliehthyidae may be diflded into two subfamllies:

1. Aplocheiliehthylnas (now subfandly): Body not excessively deop and the abdomen not sharply compressed; peIvle fIns usually inserted more posteriorly; none of the branchiostegal rays detached.

Genera: Aploche1l1ahthys, Cynopanchax, Plataploche1lus, Mleropanchax.

2. Procatopinae (new subfamily): Body deep, abdomen compressed; pelvic IIns placed anteriorly under or almost under the pectoral base; one or two brenchiostegal rays detached and projecting backward.

Genera: Procatopus, Lamprichthre,

Hypsopanchax, Platypanchax. 


\section{Relationships and Taxonony of Lamprichthys tanganicanus}

The relationships of Lamprichthys tanganicanus have been commented upon in connection with a similar question in eplochellichthylans (Group VI). However, 1 t seems appropriate that these relationships should be consldered separately because the osteologlcel characters of this species have been confused in the past and because an understanding of its taxonony and precise relat1onshlps have suffered accordingly.

This monotypic gemus appears to be confined to Lake Tanganglka in Africa. Myers (1951) established a separate subfamily for 1ts reception. In doing this he relied ahleng on the observations of Regan (1911) for osteological characters of the specles and assumed that, since Regan had included the species in the subfamily Fundulinas, the parietals were present and the epipleurals simple. Similarly Myers incorporated Regan's statement that the basisphenold was present.

Later, while studying Lampriehthys tanganicanus in more detall, Myers (1936) Ilsted the osteological characters of the species. This time, however, he did not make and comment about the parietals, but again stated that the basisphenold was present.

I have prepered a skeleton of one specimen of this species and IInd that the parietals are absent. Further, as in 211 the other eyprinodonts which I have included in this study, the basiaphenold 1s absent. I an, however, in complete agreement with Hyers' (1951: II) corment that in the members of the subfamily Lamprichthylnae "The pectoral Pins are set high, possibly indicating relationship to the Aplocheilichthyin1." 
In connection with the discussion of the relationships of Croup VI, I have pointed out that there is a surficient agreement between Lamprlchthys and aplochellichthylans, especially Procatopus, to fustify the suggestion that two aubfamilies be erected within one family, Aplocheilichthyldae, to show this relationship. Moreover, the osteolog of Lamprichthye tanganicanus 1s very simblar to that of the aplochellichthylans included in this study. The aceount given for then will apply equally to this species except for the greater number of vertebres and the presence of more numerous (12) expanded haomal arches in Lamprichthys tanganicamus but, as has been polnted out previously, the haamal arehes are also expended in Procatopus.

Lampr-lchthys tanganicanus seans to be a modirled descendent of an aplochellichthys-11ke ancestor which might have gained access into Lake Tanganyllka when 1 was formed in the Rift Valley during the Pliocene (Kyers, 1956). The specialisations present in Lamprlehthrs tanganicanus are adaptations to the vast and doop habitat of the lake. In this connection the following remarks of Myers (1956: 4) seem pertinent: "The peculiar athernid-like habitus and color of this Iish sets it off as one of the most interesting specializations of the eyprinodonts. Bvidently these 11ttle Plahes have the same habsts in the sea-1ike expense of Tanganylka as have the atherines in the ocean." 
GROUP VII

\section{Composition and Range}

Thla group contains a single genus Oryzias Jordan and Snyder and Its spec1es range from Japan and Central China southward to Celebes, Timor, Java and wastward to Southern Indla. The chief character of these flshes concerns premaxdIlary which is nonprotractile only in this group of eyprinodonts.

\section{Osteology}

The account which follows is based on Oryzias latipes (Teminck and Schlegel).

The head skeleton of Orrzias melastlgne (MeClelland) has been the subject of study by Ramaswant (1946) and Kullkarnt (1948). Because the head skeleton of Oryzias latipes agrees suffleiently with that of O. melastigma, only those osteologieal characterg which are of signifleance in the phylogenetic relationships of the gemus will be amphasised in the following description. For the detalls of the head skeleton the descriptions of Ramowand (op. cit.) and Iulkarni. (op. c1t.) should be consulted.

In ocmparison with Aplocheilus IIneatus (and other aplochellids) the skull of Oryzlas latipes is neither as Nat nor as wide. It is allghtly rounded posteriorly from where it gradually tapers toward the amall jaws. The pterotics are situated at a lower level than the oploties and the frontals. 
The ethmo1d region lacks a vomer. Instead the parasphenold extends considerably forward to support the mesethmoid from below. The mesethmold is composed of double ossifled laninae. The lateral ethmolds are located normally but they are small bones in comparison to simtlar bones of the aplochellids. The nasals are rectengular and are situated in their normal position.

In the orbitotemporal region the parlotals are absent but the frontals are well developed and the supraorb1tal processes of the frontals cover the eyes completaly. The Interorbital area of the frontals is rectangular as in aplocheilids. The parasphenoid is rather narrow but its anterolateral processes are well developed and extand laterally to meet the anteromeslal processes of the prootses to enclose posterior myodomes on both sides. The alisphenoids are located normally but they are not in eontact with anterolatoral processes of the parasphenolds and, therefore, take no share in the formation of the posterior myodomes. The boat-shaped postorbital is located outside and behind the sphenotic and takes no share in the formation of the postorbital wall of the eranium. The postorbital is provided with an open groove for the lateral IIne sensory eanal. The lachrymal is characteristically twisted as in aplochellids and a vertical groove runs 1ts entire length.

The otie bonss are normally located except for the sphenoties whlch are, in comparison to aplochollids, more anteriorly placed and come in intimate contact with the posterior extremities of the oupraorbital processes of the frontals, thereby oblitereting the noteh for 
the postorbital on both sides. The epiotics are provlded with slender epiotic processes whlch are pointed at their t1ps.

The oceipital region consiats of the usual four bones, the supraoccipital, the basiocelpltal and the exoceipitals. The foramen magnum is forred by the basioceipital and the exoccipitals. The supraocelpital stops short of reaching the foramen magnum and, therefore, takes no part in its formation. The baslocelpital is arehed below and bears a medien rldge ventrally. Both the basioccipital and the exocelpItals are provided with condyles for articulation with the fIrst vertebra. The first vertebre bears corresponding facets for the exoccipital condyles and also has a distinet neural spine.

The palatoquadrate bar of the mandibular arch shows only two osstelcations, the quadrate and the autopalatine, and to these the mesopterygold is attached from behind. The metaptarygoid is absent.

The upper and lower jaws, although containing the same bony elements as in other eyprinodonts, included in this study, have a distinctive organdzation.

In the lower Jaw, a dentery, articular, angular and sesamold articular are located in their nornal positions. In the upper faw the premaxdllee are normally located and the premexillary processes are short and broad as in aplochellids. The premaxillary processes of the two sides are very close together and pass over the mesial processes of the maxillae to come in contact with the ossified mesethmold. The mexdlia is modifled Jifferesitily than in any of the other eyprinodonts Ineluded in this study. The mesial process of the madlla 
Is elongate, very prominent, and rums under the premaxdllary process of Its side to lie in intinate contact with it. The upper portion of the descending limb of the maxdila has an anterlor membranous expansion which overlaps the outer edge of the premaxilla. The autopalatine has a bifld rostropalatine process which encloses between its extremities a portion of the descending $11 \mathrm{mb}$ of the maxdlla.

The arrangement and relationships of the premaxdlae, maxdlae and the rostropalatine processes of the autopalatines is such that the premaxillae fasl to form protrusdble jaws. The ethmopelatine process of the autopalatine is absent.

The premaxdilee and the dentary bear conleal teeth but there is some sexual dimorphism in the number and the nature of the teeth. The teeth are fewer in the wales and, on both the dentary and the premedillary, they are arranged in two rows. The teeth in the outer row, especially at the angle of the mouth, are considerably larger than those of the inner row. In the females, however, teeth are more numerous on both the dentary and the premaxdila. These teeth are arranged in a band and all of them are small and conteal. Such sexual dimorphism of teeth also has been deseribed by Sundra Rej (1916) and Kulkarni (2948) for Oryzlas melastigma.

The opercle bones are disposed as in the other cyprinodonts. There are, however, eome modifleations in their shape. The opercle is quadrilateral in shepe, but otherwise it is norrally located. The suboperele does not differ from that of other eyprinodonts. The interoperele is broad posteriorly and considerably elongated anteriorly, 
for about two-thirds 1ts length. The preopercle and especially 1ts horizontal portion is comparatively amall. The preoperele, moreover, extends only for a short distance below the symplectic and does not reach the quadrate bone.

As in Oryzias melastigna deserdbed by Kulkami (1948), the interhyal is also absent in Oryzias latipes. The epihyal, the ceratohyal and the bypohyal are norally disposed. Iulkarnt (op. e1t.), however, reported the ebsence of hypohyls in Oryzias melastilema, but In Oryzias latipes the hypohyal on each side is present and reprosented by a single bony plece.

Both the basihyel and the urohyel are nornally disposed and are similar to Oryzlas melestigna as described by Kulkarnd (1948).

There are IIve branchiostegals erranged in two groups as in other eyprinodonts. The PIrst group contains one ray while the second group consists of four branchlostegals on each stde.

The branchial skeleton conalsts of $\mathrm{flv}$ branchial arehes; the PIrst four bear glll silaments and are normally disposed. The fifth arch is modifled into lower pharymgeals aimilax to those of Oryzias melast1gma as deserlbed by Iulkarni (1948), but d1ffers considerably from other cyprinodonts in the shape of the lover pharyngeels (IIg. 56A).

Except for the second epibranchial which is amall and noctular, the other three eplbranchials are similar to other eyprinodonts deseribed so far.

The first pharyngobranehial is eartilaginous, the second Is a mall ossifled plece provided with conical teeth, but the third and 
the fourth are fused Into a single well-developed plate. The latter bears towards 1ts vantral surface about fourteen rows of small confeal. teeth.

There are three bastbranchials, as in aplochellids, and fifteen gill-rakers attached to the anterior surface of the IIrst ceratobranchial.

Sumary of Sigmifieant Osteological Charecters of Croup VII

Ittrmold Region

(1) Mesethmold ossified composed of double laminae.

(2) Vamer absent.

Orbitotemporal Reglon

(3) Parietals absent.

(4) Posterlor myodome formed by the union of dorsolateral processes of the parasphenoid and the anteromesial processes of the prootic; allsphenoid takes no part in 1ts formation.

(5) Intororbital area of the frontals rectangular; supram orbital processes of the frontals less developed in comparison to Funculus and aploche1lids.

(6) Sphenoties are anterlorly placed and come in contact with the posterlor portions of the supreorbital processes of the frontels, thereby obliterating the notch for the postorbital on both sides.

(7) Postorbital is small and boat-shaped. 
(8) Foramen magnum formed by the basiocelpltal and the exocelpitals; supraoceipital stops short of reaching the foramen and therefore takes no part in its formation.

(9) Bastoceipital and exoceipital condyles well developed.

(10) Neural arches of first vertebra separate from the ocelpital reglon; no gap between f1rst and second vertebrae.

(11) First vertebra with a distinct neural spine.

otie Reglon

(12) Bplotic procesaes present.

Visceral Skeloton

(13) Wetapterygold absent.

(14) Toeth conicel, show sexual dimorphien.

(15) Fremaxdllary processes short and brosd.

(16) Upper portion of the maxdlia expanded and supports a simflar expansion of the premardila from below, thereby making the premadila nonprotractile. Maxdlia with a woll-developed wesial process and lese-developed outer process.

(17) Autopalatine with two well-developed processes toward its upper end. These processes form a notch into which the maxilis is lodged and thus adding to the nonprotrusIbility of the jaws.

(18) Lachrymal characterlsticaliy twistod and narrow (aplochellid-11ke). 
(19) Hypohyal on each side is represented by a single bong piece.

(20) Branchiostegals Alve, arranged In two groups 3 first group With one ray wille the second group consists of four rays.

(21) Third and fourth pharymgobranchlals flased to form a large upper pharyngeal plate with numerous rows of emall conical teoth.

(22) Three basibranchlals.

Other Reglons

(23) Posttomporal unforked (F1g. 56B).

(24) No oupracles thrum.

(25) Transverse procesaes of the precaudal vertebrae elongated.

(26) Haemal canal. wide.

(27) Hypurar blesd (F1g. 59).

(28) Pelvie girdle with an external lateral process (F/g. 56C).

(29) A large space between clelthrum and coracold (Fig. 568).

(30) No intarhyal.

(51) Preopercle slender and not extending below the guadrate. 


\section{Relationships of Oroup VII}

In general the genus Oryzlas shows relationships with the world-wide aplochellids in posseasing the following characters:

(a) a very narrow preorbital with a vertical, median, nerrow groove running throughout its entire length,

(b) three ossteled bastbranchials,

(c) short and broad premaxillary proeesses, and

(d) prominent prezygapophyses which join to onclose canals.

In particular the genus Oryzias shows relationships with the Old World aplochellids in possessing the following characters:

(e) absence of subcleithral bone, and

(f) absence of a supracleithrum,

In possessing nonprotrusible premaxdularies, onlarged upper and lower pharymgeals with munerous rows of teeth, and external lateral processes in each half of the pelvie girdle, Oxyzias shows peculiar1ties of 1ts owm.

In possessing high set pectorale Oryalas resombles aploche1lichthylans (Ineluding Lampriehthys).

In the loss of a vomer this genus agrees with the Peruvian genus Orestias.

The characters (a), (b), (e) and ( $f)$, however, are pecullas to the Old World aplocheilids and it is from this stock that Oryzlas seems to have been derived. In the course of Its evolution the genus Orrzias, therefore, seems to have retained certain ancestral characters, 
sequired Its om peculiarities, and come to resemble superfieially rather widely separated forms (both aplochellichthylans and Orestlas) with which it is not directly related.

Hyers (1931 and 1958) assigned Oryzlas as the sole member of the tribe Oryziatind whleh he (1938) put in the oubfamily Fundurinae. Because of the peculiar organdzation of the genus Oryzias with its nonprotrect1le jaws and absence of vomer, opdnions have been expressed that It mey represent a separate subfamily or even a family. In this connection Myers (1958: 28) remarked that "If preliminary results can be belleved, the gemus Oryzias, which may represent a different gubfanily or even a family, has lost even the prevomer itself." Because my observations further support 14yers' conelusion, it 1s suggested that Orrzias be put in the separate fandly Oryziatidae, This action would recognize not only its distinetive nonprotractile type of jaw but also the geographic entity of the genus. 


\section{GROUP VIII}

\section{Composition and Range}

This group contains a single genus Orestias Cuvier and Valenciennes, with several species all of which seem to be confined to lakes and rivers of Central Peru, Eastern Bolivia and North Central Chile.

The following account 18 besed on Orestias agassizil Pellogrin.

$$
\text { (FIgs. } 52 \text { and } 53 \text { ) }
$$

The occipital region of Orestias agassizil is made up of four occipital bones as in other eyprinodonts. The excocipitals alone form the sides and the dorsal portion of the foranen magmum. The Noor of the latter structure is formed by the basloeeipital which beare an ocelpital condyle for articulation with the centrum of the first vertebra. The excocipital condyles are present, although they are not as conspicuous as in aplochellids or fundullds. The first vertebra has well-developed articulating surfaces for these condyles but 1ts neural arches are separate from both the supraoceipital and the exoceipitals. Both the jugular and the hypoglossal foramena are normally disposed on the ventral surface and the lateral wall of the exoceipital respectively. The supraocipital processes extend beckward from the dorsal surface of the supraocelpital.

The detalls of the otic bones are similar to other cyprinodonts. The oplathotic is absent. The anteromesial process of the prootic is 
present and there 1s a prominent cartilaginous area between the epiotic, prootic and the frontal on elther side.

In the orbitotemporal region the parietale are absent; the frontals are extensive and, in the posterior orbital region, enclose wide notches for the postorbitals. The postorbital, however, is very small and Is located toward the anterior surface of the sphenotic process. The supraorbital processes of the frontals are fairly vell developed although not to the extent as found in fundulids or aplochellide. The parasphonoid is normally disposed but its dorsolateral processes are small and do not extend laterally to moet the alisphenolds, which are located in their normal position. The lachrymals are wide bones located in front of the orbits. The basiaphenold 1s absent.

The ethmoid region of Orestias agassizil is differently organ1zed from other cyprinodonts except Oryzias. The nasals are found and are located on the dorsal aspect of the skull. As in aplochellids, the lateral ethmoids are extensive, especially their anterolateral processes. The vomer is absent. The only other genus which lacks a vomer is Oryzias. In this respect these two genera seem to be unique among cyprinodonts. Evidently the voner has been lost independently In each of them and 1 ts absence does not show any direct relettionship, for they differ in other important characters which are presently to be mentioned. 


\section{Visceral Skeleton}

The metapterygoid is absent. The dorsal process of the maxdlla is well developed, while the mesial process is amall. The lower extremity of the maxdila is rather broad and round. The premaxillary processes are small and pointed at their extremity. They extend beckward over the small mesial processes of the maxdllae. The premarillae bear two rows of confeal teeth. The autopalatine is norwally disposed and bears both the rostropalatine and the ethwopalatine processes. The quadrate is normally disposed. The mesopterygold is present as in other cyprinodonts. The hyomandibular is elongate and the symplectic is normally disposed.

There are only two ossifled basibranchials. The hypohyal is represented by a single piece on each side. In other detalls the branchial arches tend to resenble the conditions as in Fundulus and 1ts allies. The lower pharyngeals are provided of th gill-rakers toward their anterior surfaces. All the four eptbranchials are distinct. The first pharymgobranchial is cartilaginous; the second is separate but elose to the single plate formed by the union of the third and the fourth pharyngobranchials. There are about 14 gillraicers on the anterior side of the first gill-areh. All the gillrakers are pointed as in erprinodontids and the funculids. Th1s is in contrast to the aplochellids where, excopt for the pointed gillrakers on the anterlor side of the first arch, all the rest are rosette-shsped at their tips. 
The basthyal, the urohyal and the hyold cormu are normally dieposed. The hypohyel on e1ther side is represented by a single piece. As in most of the aplochellids included in this study, both the upper vertical and the lower horlzontal portions of the preopercle are broad. The other opereular pleces are normally disposed. There are Ilve branchlostegals on each side; the flrst group contains only one branchioategal ray, while the second group has four. The posttemporal is unforked.

Sumnary of S1gnifleant Osteological Charactors of croup vitrir

Ethmo1d Reglon

(1) Mesethmoid ossifled and composed of double laminas.

(2) Voner absent.

Orbitotemporal Region

(s) Parietals absent.

(4) Posterior myodiome absent.

(5) Dorsolateral processes of the parasphenoid amell and not meeting the allophenolds.

(6) Postorbital small.

Occipital Rogion

(7) Foramen magnum formed only by the exceelpitals and the basioecipital; supraoceipital takes no part in 1ts formation.

(8) Both the basiocelpital and excocipital condyles well developed. 
(9) Neural arches of IIrst vertebra separate from alcull; Iirst vertobra with a distinet neural apine.

\section{V1sceral Skeleton}

(10) Motapterygold absent.

(12) Teeth conteal and biserial in Orestias agassizii.

(12) Prewaxdilary processes elongate; extending over the enall mesial processes of the maxdlla.

(15) Anpohyal on each side represented by a single plece.

(14) Five branchiostegals in Orestias agassizil.

(15) Third and fourth pharymgobranchials rused.

(16) Two basibranchials.

\section{Other Reglons}

(17) Posttomporal unforked.

(18) Traneverse processes of precaudal vertebrae elongated.

(19) Polvle fins absent.

(20) Prezygapophyses prominent and jolned to enelose canals.

(21) Preoperele as in most other aplochellids included in this study.

(22) Anterolateral processes of the lateral ethmolds elongated.

(23) Median hypural aingle and fan-shaped. 


\section{Relationships of Group VIII}

The genus Orestias, consisting of several species, seems to be confined to Lakes and stagnant portlons of the rivers of the high plateaus of Central Perv, Eastern Bolivia, and North Central Chile, but the linits of the distribution are not known. Its point of greatest abundanee, both in mubers of Individuals and species is Lake Titicaca. It is also found in Lake Poopo, Lake Jmin and in swaller lakes, rivers, brooks and ditches of the upper reaches of the Ramis, Urubembe, and RImae Rivers. The genus oecurs at altitudes from 7,000 to 16,000 seet, but population densities are greatest around 12,000 feet (Bigermann, 1920; Myers, 1951; E1genmann and Allen, 1942\% Barg, 1940 and Techernavin, 2944, glve additional distributional data).

Being found only in the highlands and reaching probably the highest altitude Inhabited by Plahes, the question of the origin and the relationships of this genus has excited much interest. The other species of flsh which are found associated with it belong to only those genere which are mountein scalers and are at home in torrents from near sea level to the heights, and they may have worked their way up the present streams. Orestias, on the other hand, is not found in the torrential portions of the streams, but in backwaters, lagoons, swamps, quilet places of the rivers and lakes.

Therefore, it is unlikely that Orestias has managed to alimb the presently exdsting streams. Furthernore, it has no relatives in the Lowlands and 1t has never been found below 7,000 feet. It seems to be an ancient genus whose origin is bound up with the origin 
of the Andes. It is possible that ancestors of this genus were pushed up by the rise of the Andes, thus 1solsted from their relatives, which later became virtually extinet in Peru (Eigenmann, 1920, and Bigenmann and Allen, 1942).

The relationships of Orestias have been discusaed to some extent along with a similar question about Bapetrichthys. I few points, however, need further comment.

Q11bert (1893), Jordan and Evermann (1896), and E1ganmann (1920) hypothesized that Bmpetrichthys and Orestles were related genera. Jordan (1925: 158) placed these two genera in a distinct famly, the Orestildae. On the other hand, Myers (1931) commenting on the same problem and utilizing some of the skeletal characters, coneluded that the two geners were unrelated and placed Mmpetriehthys in the subfandly Fundulinae and created a separate subfandly Oreatiatinae for the solo reception of Orestias. Hubbs (1932: 2) whlle discussing the relationahlp of the two genera commented that "There 1s probably no immediate relationsh1p between Bmpetrichthys and Orestias, although both were probably derlved from some such basic stock as Profundulus ..." The diagnostic characters of Oresties, as listed by Regan (1912) and Myers (1932), relate to the bifld or trifld nature of the epiplourals and the absence of parletals. Because the eplpleurals are simple in Orestias agassiz11, this character cannot be used to dlagnose the genus. However, the absence of the parletels, the vomer, and the pelvics, are characters of considerable signiflcance and taken collectively they diagnose the genus from other cyprinodonts. 
Among the oviparous cyprinodonts the genus Orestias seens to be pecullarly organized in that some of 1ts osteologlcal characters resemble those of the fundulide and the aplochellids vhile in other respects it shows peouliarities of its own.

Orestias differs from fundulids (Group III) in the following:

(1) No parlotals.

(2) Letaral ethnolds with well-developed anterolateral processes.

(3) Prominent prezygapophyses whlch join one another dorsally to enclose canals.

(4) Mirst vertebra with a distinct neural spine.

(5) Small postorbital.

(6) Pharyngeal teeth with a slight shoulder as in Rivulue.

(7) The shape of the preopercle is more like most of the aploohellids included in this study.

In the above mentioned characters, Orestias not only differs from the fundulids but also appears to resemble the aplochellids (Group V). It differs from the aplochellids in the following respectss

(1) Absence of metapterygo1d.

(2) Two besibranohials instead of three.

(5) Wide instead of a narrow preorbital (lachrymal).

(4) Hypohyal on each side represented by one instead of two pieces.

(5) Third and fourth pharyagobranchials freed instead of separato. 
(8) Ossified Instead of a cartillaginous mesethwoid.

(7) Absence of vomer.

In the absence of a vomer, Orestias shows superfle1al resemblance to the wldely separated Oriental genus Oryzies.

It seems, therefore, that with the uplift of the high Andes, an ancestral stock beceme fsolated and subsequently evolved into the genus Orestias. Apperently, the ancestral stock was close to the aplochellids, because Orestias st1Il possess some of their characters as montioned above. In the absence of a fossil record, this hypothesis must remain tentative.

Several authors have considered the group of Orestias as a famlly or a subfamily (Orestiasint Bleeker, 1860, Orestiformes Bloeker, 1863; Orestiline G111, 1895; Regan, 1911; Fowler, 1916; Orestildae Jordan, 1923; Orsstinae Stark8, 1926; Orestiatinae Myers, 1951, Orestinl Berg, 1947). Tehernarin (1944), while revising the gemus Orestias, has assigned to 1 some 20 species, 2 subspecies and three forms of lesser taxonomis afgnifleance, He arranged these species Into four groups and commented that "There is a good reason to consider Orestias as a group of more than generic signiflcance, whlch could be divlded into several genera." However, he did not name these divisions. The taxonomie implieations of the above divisions will be diseussed In the Iinal section of this study. 


\section{DISCUSSIOU AND SUMAARX}

The osteological IIndings which have been presented reveal that the oviperous eyprinodonts, eurrently recognized under the fanily Cyprinodontidae, contain at least seven and possibly elght phyletic lines of evolution. Each of the seven Iines is represented by a group of forms separable from the other groups by a number of osteological features and also by geographleal distinctions. It has not been possible, however, to find anv major osteological differences between the remalning group, Valencia (Oroup IV) of the Nediterranean region (Spain), and the fundulids (Oroup III) of North America desplte their widely soparated geographic distribution. It is possible new approsches may prove more informative.

The relationships of the elght groups in reference have been discussed (following the presentation of date for each group) and, consequently, it 1s now poselble to venture a sumary of ostsological characters peculiar to the oviparous eyprinodonts, d1seuss the paleontological data avajlable for the group, consider ancestral origins, examine evolutionary trends, and mention such taxonomic implications as have become evident. 


\section{Magor Osteological Characteristics of} oflparous Cyprinodonts

The oviparous cyprinodonts share a number of osteological

features in cownon and these characterlatics, taken as a whole, lend support to the integrity of the group. The following attributes were found in each of the forms strdied:

(1) Brain case incompletely ossteled; small cartilaginous areas persistent in adults; eartilaginous interspaces present between wargins of replacing bones.

(2) Moxdllae edentulous and not entering gape; biting part of upper jaw formed by premaxdulae exclusively.

(3) Orbitosphenoid, besisphenoid, opisthotic and mesoeorecold abeent.

(4) Branchiostogals arranged in two groups on each side.

(5) Frontals large and extensive.

(6) Mirst vertebra without ribs and transverse processes (parapophyses); epipleurals attached directly to neural arches.

(7) In rewaining precaudal vertebrae, transwerse processes present and coossirled with centre; ribs present and articulated with transverse processes; epipleurals attached to upper proximal ends of ribs.

(8) Supraoceipttal processeв present. 


\section{Osteological Features Peculiar \\ to Different Groups}

In contrast to the shared characteristics, the groups differ from each other in many respects. Some of the more conspicuous varlations are Ifated here in the form of a sumbary.

Mesethmo1d

Two major types of masthmo1ds oceur in the eyprinodonts under discusaton:

(1) Cartilaginous (as found in aplocheilids, aploche1lichthylans, and aphanids), and

(2) Ossifled and composed of double land nos (as found in cyprinodont1ds, Pundulids, Valencia, Orestias, and Oxyg1as).

Anterolateral processes of the lateral ethmo1ds

These processes are considerably elongated in aplocheillds and in Orestlas but they are small in all the other groups. Vomer

The vomer is entirely absent in Oreatias and Oryzias; in all the other groups it is present and devold of toeth except in the aplochellids which have a vomer provided with a amall patch of confeal teeth towards Its anterior extremity. Parietals

These bones are invarlably present in fundulids and Valencia; invarlably absent in eyprinodontids, aphanids, aplocheiliehthylans, Oreatias and Oxyzias; they are variable, however, in aplochell1ds. 


\section{Postarlor myodome}

This structure is varlable both betwoen the groups as well as within the groups of eyprinodonts under consideration. In eyprinodont1ds, aphan1ds, aplochellichthylans and Orestias, it is Invarlably absent; in fundulids and aplochollids, it is present in certain genera but absent in others, and in Valencia and Oryzias, it is present. Moreover, the structure of the posterior modome is variable as has been pointed out in connection with the descriptive osteolocy of Croups III, IV, V and VIr.

\section{Parasphenold}

The parasphenold 1s well developed in all the groups, but its anterior processes are smell and locsted toward the inner aspect of the parasphenold in all the genera which lack a posterlor myodome (F1gs. 8B, 49A, 52B and 54B). In the genera whlch possess a posterior myodome, the anterior processes of the parasphenolds are long and laterally situated (F1gs, 52, $53 A$ and 46).

\section{Alisphenolds}

The allsphenolds are amall bones and are situated towand the posterolateral corners of the orblts in all the eyprinodonts under consideration (PIgs. 8B, 49A, 52B and 54B). These bones are, however, slightiy enlarged in all the genera which possess a posterior myodome (Figs. 52, 354 and 46 ).

\section{Supraorbital processes of the frontals}

These processes are amall, alightly convex dorsally and do not cover the eyes completely in elther the eyprinodontids or in the three 
fundultd genera (Lucania, Chriopeops and Leptolucania). In all the other genera, these processes are extensive, flattened dorsally and completely cover the eyes.

Notch between the supraorbital process and the sphenotie

In aploche1l1ds, aploche1lichthylans, and Orestias this notch 1s very extensive whlle in all the other genera it is small except In Oryzlas which lacks a notch because the sphenotie is in elose contaet vith the supraorbitel process of the frontal.

Postorbital

The postorbital is very smell in all aplochellids except Aplochellus and In Orestias; in all the other groups it 1s well developed.

Lachrymal (Preorbital)

Th1s bone 18 wide in all the groups except in the aplochellids and Oryzias (Group VII) both of which have a charaeteristleally twisted lachrymal medially grooved along 1ts outer border. Eplot1c proeesses

These processes are present in Orys1as, all fundullds except Adinia and Leptolucenia, whlle they are also absent in all other cyprinodonts.

Supraoce1pital

Except in cyprinodontids, in which the suprsocelpital extends posterior 1 y and forms a conspleuous dome-shaped structure over the foramon magnum, this bone stops short of reaching the foramen in all the other groups of eyprinodonts. In other words, in eyprinodont1ds 
the foramen magnum is formed by the besioceipital, exoceipitals and the supraocelpital while in all the other groups the foramen ragnum Is formed entirely by the basioceipital and the exoceipitals. Exoceipital condyles

The exoccipital condyles are absent in the cyprinodontids whlle in all the other groups these condyles are vell developed. Premexdilary processes

In cyprinodontids and aphanlds the premaxdilary processes are typically mall and pointed at their tips and they do not extend beckward over the mestal processes of the maxdllae. In aplochellids, aplochellichthylans, and Oryzlas these processes, although small, are very broad and extend posteriorly over the mesial processes of the aaxillae. In fundulids the premaxdllary processes are of three types and extend over the mesial processes of the maxdilaes anall and fairly brosd in Profundulus, amoll and narrow in Bupetrichthys and Crentohthys, and long and narrow in Fundulus, Adinia, Lueanla, Chriopeops and Zeptolucania. In Valencia the premadilary processes are long and narrow and extend over the mostal processes of the maxillae. Maxdila and autopalatine processes

In Oryelas the upper portion of the maxdila is expanded and supports a sivilar expansion of the promaxdlla from below, thereby making the premexdlla nonprotractlle. Moreover, in this gonus the two well-developed processes of the autopalatine form a notch into which the maxdlla is lodged, thus adding to the nonprotruslbility 
of the jaws. In all the other groups, the premaxdlla, the maxdlla and the autopalatine are normally disposed and the jaws are protractile. Articulation of the skull and vertebral column

In eyprinodont1ds the skull articulates with the vertebral column through the besioceipital condyle. Horeover, the neural arehes of the flrst vertebra in the eyprinodont1ds are applied elosely to the oceipital region to form a etrong articuiation. In all the other genera the articulation of the akull with the vertebral column is through the basioccipital and the exoccipital condyles. The neural arches of the I1rst vertebra in all these groups remain separate from the oecipital region.

Flrst vertobra

As mentioned above the neural arches of the first vertebra ere In intimate union with the occipital region in cyprinodontids and therefore the vertebra lacks a neural spine, whereas they are separate from the ocelpital region in all the other groups. In fundulids (except Profundulus, Empetrichthys and Crenichthys) the neural arilies of the flrat vertebra are not only aeparate from the oceipital reglon, but they are also separate from one another and do not meet above the neural canal and, therefore, they, too, lack the neural spine. In Produndulus, Bmpetrichthye, Crenichthys and Valencia, al though the neural arches of the first vertebra are separate from one another distally, a transverse bony septum connects them just below their tips. In all the other groups the Pirst vertebra has a distinct neural spine. 
In all the groups, except cyprinodont1ds, the first vertebra possesses two corresponding facets, toward its anterlor end for articulation with the exoecipital condyles. Such facets are, however, absent in the eyprinodontids.

\section{Posttemporels}

The posttemporal is distinctly and invariebly forked in cyprinodont1ds, aphanids, Profundulus, Bapetrichthys, Crenichthys and Pundulue kansaes it is variable (Forked to unforked) in aploeheillds; it is distinetly unforked in the other frundulids, Orestias, Valoneia, aplochellichthylans and Oryzias. Branchlostegals

The number of branchlostegal rays in the several genera varies Prom three to six.

Eypohyal.

In aplocheilids the hypohyal on each side is represented by two bony plecess wheress in all the other groups it is composed of a single plece.

Interhyal

Except in Oryzlas, which lacks an interhyal, this bone is present in a.1 the other groups. First pharymgobranchlal

The first pharyngobranchial is eartilaginous and devold of teeth in all the groups except Mloridichthys carpio in which it is ossified and possesses two rows of conicel teath. 
Third and fourth pharyngobranchlals

These are distinetijy separate in aplochellids but in all the other groups they are fused to form a single plate. Basibranchials

There are three ossifled basibranchials in aplochellids and Oryzias; in all the other groups there are only two ossifled basibranchials.

Transverse processes of the precaudal vertebrae

These are short and eup-shaped In eyprinodontids; in all the other groups they are elongated. Median hyourel

This structure is trifld in Aplochellus panchax; bifld in the other aplocheilids and Oxyz1as; In Profundulus, Bampetrichthys, Creniehthys and Valencia it shows indieations of divialon by a medsan sutures and in the other rundul1ds, eyprinodontids, aphandds, and Orestias it is a fan-shaped piece without external indications of division.

\section{Pressgapophyses}

The presygapophyses are prominent and join dorsally to enclose canals in aplochollids, Orestias and aplocheilichthylans; they are prominent in fundulids, Valonela, and Oryzlas, although not joining dorsally to enclose eanals 3 in eyprinodont1ds and aphanids the prezygapophyses are small.

\section{Haemal canals}

The haemal canals of the flrst few caudal vertebrac are very wide in aplochellichthians; less wide in aplocheilids, fundulids, 
Oryzias, Orestias, and Valenclas and narrow in cyprinodontids and aphantds.

Supracle1 thrum

Except in Leptolucenia, in which the supracleithrum is absent, this bone is present in all genera under consideration.

Pectoral rays

The pectoral rays are set high on the body in aplochellichthylans (including Lamprelehthys tanganleanus), and in Oryzias; in all the other groups they are set low.

Space between coracold and clelthrum

This space is very vide in aplochollichthylans (Ineluding Lamprichthys tanganleanus), Aplocheilus, and Oryzlas; in all the other genera it is narrow. 


\section{Cyprinodont Paleontology}

Mayr (1955: 42) in a general discussion of Phylogeny and Classification remarked " .. paleontology and comparative morphology are on the whole the most productive sources of phylogenetie infornation." It is pertinent, therefore, to revlew here avallable peleontological information eoneerning eyprinodonts before entering Into the diseussion of a generalised eyprinodont stock, trends of evolution in oviparous eyprinodonts, and taxononile problems concernIng these Prshes.

The following list of fossil eyprinodonts has been complled from a number of sources but principally from Cope (1891), Regan (1911), Eastman (1917), Jordan (1924, 1925), White (1927), Myers (1981), Hibbard and Dunkle (1942), Robertson (1943), Nuller (1945), and Berg (1947).

Pachyleblas Woodward. Upper Miocene of the Mediterranean reglon. Carrlonellus White. Lower Tertiary of Ecuador.

Proleblas Sauvage. Oligocene and Mloeene of Europe. Brachyloblas Priem. (?) Miocene of Persia. Pooc1lopg Sauvage. Lower Miocene of France. Cephyrure Cope. ( ( ) Oligocene of South Dakote. Proballostomule Cope. (?) Oligocene of South Dakota, possibly as late as Pleistocene, according to Schmeffer as quoted by Rossen and Gordon (19538 38).

Fundulus (Including Parafundulus Bastman) Lacepede. Pliocene and Pleistocene of Lahontan basin (Hevada and Callfornia), 
Pliocene of Death Valley National Monument, Callfornia, Mohave Desert, Callfornia, and P1locene of Kansas. The following speeles are knowns

Fundulus nevadensis (Bastman). Lahontan besin, near Hazen, Neveda.

F. erdis1 (Jordan). Lahontan beds of northern Los Angeles County, California.

F. curryd and F. eulepis Miller. Death Valley National Nonument, Inyo County, Callfornis.

F. davdae Miller. Mohave Desert, Callfornila. Pliocene or early Pleistocene.

F. sternberge Robertaon. Pliocene of Kansas.

I. detillae Hibbard and Dunkie. Pliocene of Kansas.

Cyorinodon breviradius Miller. Death Valley National Isonument,

Inyo County, Callfornia. Found in the same beds as

I. curryl and I. eulepis (MUler, 2845).

As will be apparent from the following review of the literature, ideas coneerning the relationships of fossil cyprinodonts have suffered from a certain anount of confusion. This is not surprising when it is considered that the basis for such relationships, comparetive osteological information of living forms, has been altogether absent.

Regan (1811: 525) Included Pachyleblas of the Klocene in the subfamily Cyprinodontinae along with such living genera as Cyprinodon, Leblas (now Aphanius) and Tellia (now Aphanius). Whito (1927: 522) 
deseribed Carrionellus from the (?) Lower Mlocene of Beuador and remarked: "The trieuspld teeth and the absence of secondary sexual characters refer Carrionellus to the Cyprinodontinae of Regans' clessification (1911: 325). The multiple row of teeth provides a valid generic distinotion from 11ving genera, which is further amphasized by the position and uniformity of dorsal and anal IIns." Myers (1951; 12) included both Pachyleblas and Carrionellus in the subfamily Cyprinodontinae. Niller (2956:7-8), on the other hand, thought that Carionellus might not be the member of the subfamily Cyprinodontinas and wrote: "The Tertiary fossll eyprinodontid Carionellus (White, 1927), of Equador, has been included in the Cyprinodontinae because of its trieuspld teeth (in at least two rows rather than a single row), but a study of the publlshed flgure indicates that this IIsh differs importantly from the American genera assigned to this fandly."

About Proleblas Regan (1911: 325) commented: "The Oligocene and Miocene Prolebles, Sauv., seems to be related to Funchuluss it has 52 to 84 vertebrae (A. S. Woodward, Cat. Foss. F1sh. IV p. 290, 1901)." White (1927, 522) agreed that Prolebiag "geems to be a true Funduline, . . " Hrers (1931: 10) commented that "Whether or not Prolebies of the O11gocene and Mlocene of Europe is nearer to Valencle I can not at present determine, having no material of the fossil genus." Uneertainty also prevasls coneerning the systematio position of the other genera. Fundulus camnot be elearly distinguished from living genera and the same applies to the fosall Gyprinodon described 
by Miller (1945); Gephyruxa has a forwardly placed dorsal $\mathrm{PIn}$, a amall pectoral of nine rays, and seendingly no hypural, although all the livIng eyprinodonts possess hypurals.

Although not so indicated by Cope (1891), Rosen (1953: 39 , Mg. 44), to whon the same skeleton was avallable, remarked, "OS the struetural detalls of the Proballostomus anal Iin skeloton, probably the most important for consideration of intermediate forms in the evolution of specialized reproductive organs are the supporting hewal [o1c] spines which have enlarged and rotated forward. These structures may be compared with the comparable elements in the gonopodial suspensorives of the poecillid, X1phophorous maculatus (text-11g. 45)." He further states, "In other respects, the anal IIn skeleton of Proballostomus compares favorably with those of living eyprinodonts such as Fundulus, but it even appears to be slightiy more speclallzed In the cephalo-caudal extension of 1ts actinostal plates,"

Brachylebias from the (?) Miocene of Persia, is sald to be near Proleblas and has but twenty-three to twenty-four vertebrae (F. Priem, 1908).

Except that the dorsal An 18 opposed to the ventrals, no other useful information is avallable for the Lower MLoeene genus Poecllops whteh has been reported from France (H. C. Sauvage, 1874).

It is apparent, thorefore, that not wuch peleentological Inforwation can be obtained from the fosstl eyprinodonts except in connection with the position of their IIns and such meristic characters as the number of fin rays and vertebras but at times, evan 
this information is lacking. Such meristie charaeters, as the study of the living forms shows, overlap to a considerable degree and, therefore, can be of only lintted value in deciphering the true relationships of the foss1l fores. It is also evident that all fossil cypr-inodonts need a reexanination in the 11ght of the present atudy. Too much emphasis seems to have been attached to the general form of the body and to highly varlable meristic characters, and too little attention has been paid to wore dependable osteologleal attributes of such Itens as the metapterygold, the vomer and Its toeth, the basibranchitils, the branchiostegals, the premadilary processes, the parletels, the supraorbital processes, the excecipital condyles, the IIrst vertebra, the transverse processes, the prezygapophyses, and the hypurals. All of these are important in deciphering the true relationships of fossll forms and it is hoped that the present study will provide such a basis for reevaluating the relationships of the fossil forms. If this is done then our knoviedge of the evolution of the cyprinodonts and their relationships with other groups of Plshes will be enhanced.

In the abeence of pertinent peleontological information, it would indeed have been a hopeless task to construct the phylogeny of the oviparous eyprinodonts had the study not revealed rather distinct evolutionary lines within the several Living groupe of these flshes. Moreover, eertain genere seem to have retained some of the ancestral characters in spite of many modifications in other respects. Certain genera (Aploche1lus, Eplplatys and Rivulus) appear to be bradytelle I1nes representing fairly well the ancestral stocks. 


\section{Ancestral Gyprinodont Stock}

In the lack of palaentological data and the absence of osteologieal infornation about the living forws, It seems that alnost all the views which have been expressed about a generallaed ancestral eyprinodont stock have been more or less premature. Hubbs (2924: 12) on the basis of certaln external characters of Profunculug eame to the conclusion that this genus was the most generalized cyprinodont. In this connection he renarked: " ${ }_{A s}$ the more generallzed members of the Pundulus, Cynoleblas and some other American geners of the Cyprinodontidae, as well as the less specialized Goodeidae resemble the species of Profundulus in habltus, it seems not Improbable that profundulus, of all American genera, diverges least from a general ancestral cyprinodont type. The geographical distribution of the groups in question harnonizes with such a view." The chier characters which he eited for his ecnclusions are:

(1) the absence of a genttal pouch in the adult females of Profundulus, and

(2) the dorsal and anal sins are relatively long and low, the anal composed of more rays (13-17).

The first of these characters could be considered to be generallsed and present in the primitive and ancestral cyprinodont but the second character seems to be untenable. The anal Iin is quite long in wany other genera of eyprinodonts: Procatopus has 13 to 17 , Bypsopanchax has 14 to 21, Aploche1lus has 17, RIvulus and Orysias 
have 16 to 18, and Lamprichthys has 30 anal rays. Profundulus, as has been shown in this study, seems to have been derived from some aplocheilid stock, the present-day members of which seem to be the most generalised forme and, therefore, a generallsed eyprinodont type should be wearched for within the aplochellids (Group V). Although Profundulus does not represent the most generalized type, It nevertheless seems to be the most prindtive living genus among the North American eyprinodonts. Mvers (1951: 249), on the other hand, implied that Valencia was the most generalized of all genera when he remarkeds "... this genus may represent the ancestral stock from whlch RIvulind [Aplochellind] have sprung." He, however, dId not 21st characters for the bacls of such a conclusion except that the preorbital is recheed in this genus as in aplocheilids. It is now elear that it has been just the opposite case, 1.e., not that Valencia gave rise to aplocheillds but that a stook similar to the aplocheilids geve rise to Valeneia. Mrers (1958: 28), however, seemed to have modifled his views reeently when he remarked that, " . . Instead the Oriental genus Aplochellus presents by far the largest number of basic characters that have become speclallsed or even lost in other members of the fanlly." In view of my atudy of a wide range of representative material of oviparous cyprinodonts, I tend to agree whth this recent atatement of Yyers that Aplochollus seems to be the most generalized eyprinociont. In order to be more conclusive, however, the geners whlch have not been included here need to be investigated, and also a better lonovledge of the eyprinodonts of both Africa and South America is necessary. I elte below the basis 
of uy conclusions that Aplochellus and other similar aplocheillds (Oroup $V$ ) are the wost generalized among the order Cyprinodontiformes.

The group of eyprinodonts composed of auch genera as Aplochelius in Asia; Bpiplatys, Aphyosemion and Nothobranehius and others in Afrieas Rivulus, Gynolebias and others in Central and South America form a homogansous undt. All of these genera posseas osteologicel characters which seem to have been elther dropped or modifled in difforent 21 nes of evolution in different parts of the world. They all possess a comparatively onlarged vomer and a patch of vomerine teeth, a motapterggoid, a cartilaginous mesethmoid, distinct exoceipItal and basioceipital condyles, short and broad pronadulary processes, Jaws with conical teeth arranged in a band, hypohyal on each side represented by two bony pleces, usu211y six branchiostegal rays, separate third and fourth pharyngobranchlals, three ossifled basibranchials, posteriorly directed bony processes of the pelvie bones small, proninent preaggapophyses which meet dorsally to enclose canals, median hypural bifld or trifld, and a well-deflned neural spine on the first vertebra.

Adding to the above 11 at certain other generalised characters such as the relatively low position of the pectoral fins, adaptability to different ranges of salinity, and the perennial nature of most of the species, provldes a sort of 'character pool' for this generalized besie group. This group would then seen to have given rise to other groups through modifleation of certain characterlsties and through the elimination of others. 
It 16 pertinent here to draw upon the facts of geographical distribution of aploche1IIds and other groups, for if such facts harmonise with the anatonlcal Aindings, they would supploment and strangthen each other.

The distribution of the aplocheilids is a southerly one, prineipally African and South Amerlean. In this respect the group resembles the southern perlpheral distribution of the more prindtive members of many groups of terrestr1el and fresh water vertebrates. Aplochellus, according to Kyers (1958: 28) and also according to my study, Is the most generalized genus of the group, and has a distribution (in Southern Asia) peripheral to 1ts closest relatives in Afrlee and apparently it has not Inhabited India and Malaya for long. Since, moreover, other genera of aplocheilids, both in Afrlea and South America, agree rather closely in their osteologleal features, It is entirely possible that the eyprinodonts originatod sonewhere near Africe, most probebly around the Tethys Sea which exdsts at present in remnant form as the Nediterranean Sea. From guch a center they could have spread to different parts of the world and there gtven rise to the different groups. How this dispersal took place, across the shallow coastal areas to Asia and then across the Boring Sea to North and South Ameriea, or Proie Africa to South Amerles through a narrow Pliter beldge or through a direet land connection between Afrlea and South America, is a question which must await additional information. The hypothesis that the cyprinodonts originated sonewhere around the Tethys Sea is supported by the large mumber of 
fossil oyprinodonts found in the Mediterranean region (Steinitz, 1951) and also by the distribution of the aplochellide as mentioned previousiy. Kosavig (1943) advaneed a sinllar hypothesis in his contention thet the present-day Mediterranean eyprinodonts represent a Tethys faunal relict, In order to explain the distribution of these eyprinodonts. Steinitz (2951), while discussing the distribution and evolution of the eyprinodont Ilshes of the Kediterranean reglon and the Near East, brought forward further evidence in support of Kosswigs' hypothesis. It is obvlous, however, that much additional information will be necessary on both the living and the fossil eyprinodonts before conerete concluslons ean be reached relative to their distribution and dispersal in the past.

\section{Evolutionery Trends}

The following patterns are discernible from the present gtudy as regards the trenda of evolution in the ordparous eyprinodonts? Loss of mobllity of maxdilae

In alf generallzed teleosts the maxdiae are moveable and I10 freely expeased on both aides of the head. This is also the case in the Oriental gemus Aplocheilus, but in the Afriean genus Epiplatys the maxilita has become partily embedded in the Noah of the preorbital region. This bone 1s, however, completely ambedded and practically Immovable in all the other eyprinoclonts examined in this atudy. Further, in Orysias the structure and relationships of the maxdilae and the premoudlise are such that the entire mouth is nonprotrusible. 
Reduction and modification of teeth

In aplocheilids the premaxdilla and the dentary are provided with a band of conical teeth, but in several genera the teeth have been reduced to two rows as in Chriopeops, or to one row as In Lucania. In other lines the conteal teeth have become bieuspld as in Crentehthys or trieuspid as in eyprinodontids and aphanids. The evolution of the trienspld teeth has, however, oceurred Independently on two oceasions, once in the New World eyprinodontids (Group I) and again in the Old World aphanids (Group II).

Loss of vomerine teeth and vomer

The vomer is a large bone in aplochellids and bears a patch of teeth towards its anterior end. These teeth have, however, been lost in all other eyprinodonts. In the Orlental genus Oryzlas and In the Peruvian gonus Orestias even the vomer has been lost. Again the loss of the vomer seems to have oceurred independently in these geographically separated and unrelated genera.

From low set pectorals to high set pectorals

In all the more primitive teleosts the pectoral Ins are inserted low on the sides of the body. They also are set relatively low in aplochellids. Fron this position, trends toward high-set pectorals are present in the Oriental gemis Oryrias and the African aplocheillahthylans (Including Lamprichthys). Changes in body form

In general the eyprinodonts are more or less elongated and cylindrical with a short, round, and moderately depressed head, and 
the dorsal fIn is located far back vith its Insertion behind that of the anal as in Aplocheilus and in Rivulus. In different specialised lines, however, the head and the body show deepenting and compression as in Cyprinodon, Adinta, Procatopus and Lamprichthys, and the dorsal In is located in the middle of the body or may oven originate in advanee of the anal in as in Cyprinodon, Moridichthys and Jordanella. Changes in the oceipital region and the first vertebra

In general (Croups II, V, VI, VII and VIII) the basioceipital forms the floor of the foramen magnum while the exoceipitals form the side walls and the roof of this structure and both the basioceipital and the exoceipitals bear condyles for artieulation with the IIrst vertebra. The supraocelpital stops short of reaching the foramen magnum and takes no part in 1 ts formation. The first vertebra has a distinct neural spine and its neural arches are separate from the occipital reglon. In Fundulus and Valencia (Groups III and IV), although the oceipital region is constructed on the same pattern as described above, the first vertebra lacks a neural spine because its neural arches have become free and do not meet above the neural canal. In Cyrrinodon and 1ts alles (Group I) the supraocelpital extends posteriorly to form a consplcuous dome-shaped strueture over the foramen magnun; also the exoecipital condyles are absent and the neural arches of a spineless IIrst vertebra are applied to the oceipital regton, where these neural arches share in the articulation of the skull and the vertebral column. 


\section{Changes in scalation}

The eyprinodonts usually have cycloid seales on both the head and the body. In 10osswiglahthys asquamatus, however, the scales have been lost entirely and in Lamprichthys tanganicanus the scales have becone etenoid.

Reduction and 1088 of paeudobrenchiae

The pseudobranchiae are present but poorly developed in the aplochellid: (Group V); in all the other groups they have been lost completely.

Changes in breeding behavior and life cycle

Most egprinodonts are perennilal Plahes which 11 ve for three or four years. Th1s is also true for the aplochellids in general but within this group several genera in South America and Africa heve become annuals adapted to life in 1solated pools and madholes which dry up once a year. The population then exists solely as fertilised egga buried in damp and under a hard dry top erust.

From the foregoing account and from the consideration of the relationships of the different groups of the oviparous eyprinodonts, It Is evldent that the Loss of various bony elements and the modification of others is conspicuous in the evolution of the several lines of descent. Because the aplocheilids possess the bony elements In full array and are also distributionally the most cosmopolitan, it Is reasonable to conclude that they form the basic stock from which other groups of eyprinodonts arose in different parts of the world. 
The superficial reaemblanees which these groups show to one another are due to parallel ovolution for, othervise, these groups form separate and well-defined, phyletic ent1t1es.

The phylogeny of the orlparous eyprinodonts, as Indicated by the present study, is shown in the accompanying dendrogram. On the basis of the results of others, the remaining fanilies of the order have also been included in 1t. The entire arrangenent, hovever, is tentative and must remain so until all the groups, both Viviparous and oviparous, have been compared and analysed on the basis of dependable assemblage of conmon characterlstics.

\section{Taxonomie Inplications}

The findings of the present study suggest a number of changes pertinent to the classification of the oviparous cyprinodonts, until now included in the family Cyprinodontidae. These can best be appreelated in the taxonomle background of the group, wh1ch is given below?

Regan (1911) published a classifleation of the order Mlerocyprint (=Cyprinodont1fornes) and separated 1 ts various texce Into two suborders: 1. Arblyopsoldea (amblyopsoldel Berg) and 2. Poeclilioldea (-Cyprinodontoidel Berg), the former containing the fandly Amblyopsidae and the latter Including the family Poeellisidae. He further subdivided the family Poecllildae Into seven subfamilles:

1. Cyprinodontinae, 2. Tundulinae, 8. Orestinae, 4. Characodontinae, 5. Jemynsilnae, 6. Anableplnae, and 7. Poecllilinae. Jordan (1923) suggested that more famll1es of Microcyprins (Cyprinodontiformes) should be recognized and, therefore, he ralged 


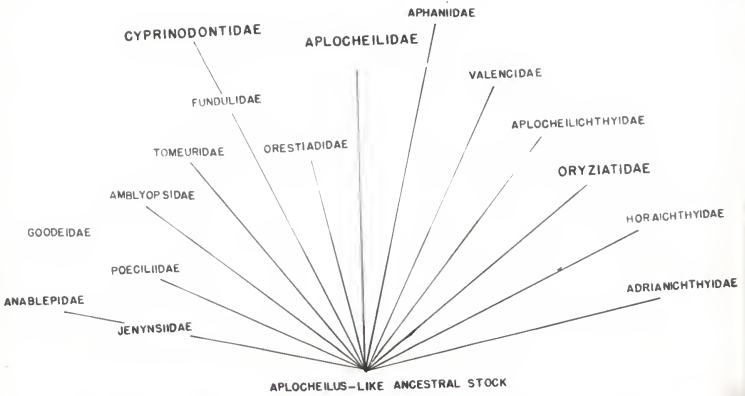

\section{Dendrogram showlng the relationshlps of eyprinodont Plohes \\ (tentative arrangement).}


several of Regan's (1911) subfamilies to Pamily status and erected a few new ones for a total of tens 1. Cyprinodontidae, 2. Orestildae, 3. Characodontidas, 4. Goodeidae, 5. Poec1lidae [ale], 6. Fltzroyidae, 7. Anablepidae, 8. Phallostethidae, 9. Amblyopsidae, and 10. Adrianichthyldao.

flubbs (1924: 4) agreed with Jordan's (2923) claselfication of the order Cyprinodontes on the whole, but proposed eertain modifications in its details. He pointed out that "The Characodontidae and Goodeldae should not be separated, for to do so would destroy the extreme naturalness of the combined group. The name Characodontinee Is synonymous with Goodeinae, wich is the older; the family should therefore be named Goodeldae." Further, he proposed that the Fitzroyldae and Anablepidae probably should be reduced to subfamily rank for, according to $\mathrm{hlm}$, the latter group probably was derived from the former, and that the nane Anablepidae holds for the combined group, being the older. Noreover, he pointed out that the name Fitzroyinae must be altered to Jenynsilnse, according to the international rules. The fandlies whtch llubbs (1924) recogatzed in the order Cyprinodontes are: 1. Cyprinodontidae, 2. Adrianichthyidao, 3. Coodeldee, 4. Anablepldae, 5. Poecilildae, 6. Phallosteth1dae, and 7. Amblyopsidae. However, nelther Jordan (1923) nor Hubbs (1924) delimited these Pamilles into two suborders (Amblyopsoides and Poec1lio1dea) as Regan (1911) had done before them.

Nyers (1928) demonstrated that the Phallostethddae were not members of the order Cyprinodontiformes, and later, whlle proposing 
a general classiflcation of the oviparous cyprinodonts, he (1931) followed Regan (1911) in recogmizing two suborders (Amblyopsoldea and Poecilioldea), but delinited these Plshes into six familless 1. Cyprinodontidae, 2. Adrianichthyldae, 3. Goodeldae, 4. Poec1lildae, 5. Jenynsidae, and Anablepidae. Further, he subdivided CyprinodontIdae into four subfamilies: 1. Fundulinae, 2, Lamprichthylnae, 3. Orestiastinae, and 4. Cyprinodontinae. Noreover, Myers (195.) subdivided Pundulinae into four tribess 1. Punculins, 2. Rivulini, 3. Aplocheilichthyint and 4. Aplocheilint. Later he (1958: 137) proposed certain nomenolatorlal changes and renamed the tribe RIvulini as Aplochellint and Aplocheilins as Oryziatind. About Adrianichthyldae he (1952: 7) commented: "They differ conslderably from the other fanflies, and may perhaps be viviparous." However, in contrast to llubbs (1924), Myers (1951) recognized Jengnaldae and Anablepidae as soparate fanilites.

$$
\text { Similarly Berg (1947), following Regan (1911), recognized }
$$
both the suborders Amblyopsoldea and Poecillodea but orected two superfamilles, Cyprinodontoldee and Poecilloldae, to accomnodate the orlparous fandlies (Oyprinodontidae and Mdrianichthyldae) in the former and the Viviparous fantlies (Goodeldee, Jenynsidae, Anablepldae and Poecllifdao) in the latter. Berg then followed Hyers (1951) in subdividing the Pamily Cyprinodontidae Into the four subfamilies montioned above.

Iulkarns (1940) erected a new Pandly Horaichthyldae to recelve Horalehthys setnal, a eyprinodont flsh which he had diseovered 
near Bombay (India). These Iishes are remarkable in that, although oviparous, the rales possess a complicated gonopodium formed by the modification of a fow anterior anal rays.

An analogous situation exdsts in the tropical American species Tomeurus gracilis whlch was long confused with the viviparous Poecllildue but It was eventually diseovered to be oviparous. The males possess a complicated gonopodium which is ut1lized, as in the case of Horatchthys setnat, to transfer spermatophores from males to females. Concerning the structure of the gonopodiun of Toneourus gractilis Rosen and Cordon (1953: 41) remarkeds "Our studies of the gonopodial detafls of Tomeurus indieate that 1ts runetional relations also may be quite different from those of poecililds." Similarly Yyors (1947) was much impressed by the structural peculiarities of Tomeurus and auggested that it may have originated independent of the main line of poecillid evolution. Both Myors (op. elt.) and Hubbs (quoted by Kullcarni, 1940: 384, Rossen, 1953, 41) proposed that the apesies under consideration be placed in a separate fand Iy Tomeuridae. In the meantime Wikolskit (1954) for the flrst tine but following Mrers (2847) and Thubbs (as quoted by Kulkarns, 1940: 384; Rosen and Gordon, 1953: 41), delinited Tomeurus grac1lis in a separate famtly (which he misspelled Tomeluridae). Further Nikolskd1 (1954) was so Impressed by the uniqueness of this species that he included the Pamily Tomeurldae in a separate superfantly Tomeluroldae (again he alsopelled the basic term). 
The above consideration of the two unrelated but oviparous fantlies Horalchthyldae and Tomeruldae in which the males are provided with gonopodia structurally and functionally different fron the Viviparous families (Goodeldae, Jenynsidae, Anablepldae or Poec1lildae), foeusses our attention on the question of the relationships of these two fandlies with the other familles of eyprinodonts, both oviparous

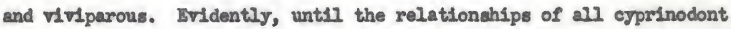
fandlies are correctly established on the basis of characteristics shared by all, grouping them into larger categories (e.g. superfamil1es) as has been done by Berg (1947) and Nikolskil (1954) is premature. From Berg's (op. elt.) elassifleation of the suborder Poecilioldea (m-Cyprinodontoldel Berg) into two superfamilles, one eontaining all the orlparous famllies and the other contalning all the Viviparous fanilles, It eppears as if all the viviparous fantlies are phylogenetically related but this 18 not the eage. In this connection the remarks of Hubbs (1924, 6) are pertinent: "The gonopodium is the chlef distinctive feeture of the Poecilisiae (es here delinited). In the other groups of VIVIparous eyprinodonts the anal $\mathrm{fln}$, to be sure, Is also modifled as an introulttent organ, but in so different a fashion as to Indicate an entirely independent origin as compared with the gonopodium. It Is highly probably that the Coodeldae, Poecllildae, and Anablepidae . . orlginated Independently from the oviparous Cyprinodontidae. It, is therefore, probable that Viviparity has been Independently acquired four times among the cyprinodont fishes. If this vlew is correct, we have in the prevent case a most atriking 
example of the independent attatment, within one group of animals, of one end through diverse adaptations. The oviparous cyprinodontidee, It would further follow, have had and probably st11l possess the potentiallty of developing viviparity. In fact, many of the species of this family show an approsech toward the viviparous condition in the development of elasping struetures and habits (see Newman 1907)."

In view of the above considerations I am recommending that the delimitation of the fandlies of eyprinodonts in two superfandlies, chlefly on the basis of their mode of reproduction as has been done by Berg (1947) and Mikolsidi (1954) be abandoned untill their natural relationships have been eatablished.

Regarding the recognition of two suborders, Anblyopsoidea and Poecilioidea, in the order Cyprinodontiformes as Plrst proposed by Regan (1911) and later adopted by Kyers (1951) and Berg (1947), $1 t$ seams that, although there is no doubt that the amblyopsids and the poeciliolds represent two divergent evolutionary lines and, therefore, the above mentioned two groupings are sound, there is a need for reVision of the present distingulshing characters of the suborder Poecllioldea. The skeletal eharacters thus far considered to be diagnostie of the suborder Poecilloidea are not universally appliceble to all representatives of the group. Starks (1904) mentioned the presence of a eircular scalo-1ike ethnoid (mosethmold) and the absence of a metapterygold as the two diagnostic features of the ouperfamily Poec1lioldea. Regan (2917), in his:classifleation of the order Mieroeyprint considered the absence of the metapterygold and 
the aniglosed nature of the palatine and the pterggoid as the two diagnostic features of the suborder Polellioldea in contrast to the presence of the metapterygoid and the separate condition of the pelatine and the pterygoid in the suborder Amblyopsoldea. Both Nyers (1951) and Berg (1917) concurred with this view.

The present investigation reveals, however, that the absence of the metapterygoid and the ankglosed nature of the palatine and the pterygold cannot be regarded as distinguishing characters of the suborder Posclilioldes, because the metapterygold invarlably is present in the aplocheilids (Group V) and the pelatine and the pterygoid are distinct in all the eyprinodonts examined in this study. The netapterygoid is absent, however, in all the other groups as delimited here. Further, the strueture of the mesethmoid in the Croups II, $V$, and VI is unique. In these groups the mesethmold is an independent plece of cartilage rather than the thin scale-like bone. The thin scale-1ike ossifled mesethmold, composed of double laminae, is present, however, In Croupe I, III, IV, VII and VIII. This indieates that Group V (aplochellids) is differently organtsed anong the eyprinodonts both in the possession of a distinct metapterygold and in having a eartilaginous mesethmold. Th1s conclusion 1s further supported by the fact that the aplochoilids possess three basibranchials, distinet third and fourth pharyngobranchials, varying pariotals (present, Indistinct or absent), varying posttemporals (alightly forked, half-way forked or unforked), and bifid or trifld median hypurals. 
Regan (1911) characterized the order Nilerocyprint as having a forked posttemporal but this bone is unforked in many fundulids (Group III), Valenc1a (Group IV), and Oryzlas (Oroup VIII). The posttemporal is invarlably sorked, however, in Gyorinodon and related genera (Group I), Aphantus and related genera (Group II), certaln fundulids (Group III), certain aplochellids (Group V) and Orestias (Oroup VII).

Th1s studi has reverled at least seven distinet phylet1c lines, within the orlparous egprinodonts, wall separable from one another in numerous osteological characters. Since these seven groups also form well-defined geographical units, I am raising each to a famtly level. Valencia (Croup IV) soems to represent an elghth phyletile line, welldefined geographleally but resembling the fundulids osteologically. Because of the lack of differentiating characters, I am tentatively Ineluding Valencla with the funculids.

A symopsis of the seven famlles of oolparous eyprinodonts together with their diagnostic eharacters is given below and it seems as If Jordan (1925: 158) had already anticipated this action when he remarked: "Hitherto the Viviparcus and oviparous eyprinodonts have been placed in a single famdly, but the differenees within the group are extensive and if the species were not all of mall size they would certainily be assigned to two or more groups." 


\section{Symopsis of the Families of \\ Oriparous Cyprinodonts}

I. Exoccipital condyles present; supreoceipital not extanding backward to form a dome-shaped structure over the foramen magnum; neural arches of the first vertebra separate from the occipital region and take no part in the articulation of the skull with the vertebral colunn; no distinet gap between the f1rst and the second vertebras.

A. Metapterygold present; vomer dentigerous; mesethmold cartilaginous; notch between the supraorbital process of the frontal and the aphenotic wide; lachrymal very narrow, usually with a vertical groove running down Its middle; pseudobranchiae present; parietals variable (present, absent or indistinct)

1. Aplochellidae, new family.

B. Metapterygo1d absent; vomer edentulous; mesethmo1d cart1laginous; notch between the supraorbital process of the frontal and the sphenotic narrow; lachrynal wide; pseudobranchlae absent; parletals absent

1. Pectorals set high; teeth conical

2. Aplocheilichthyidae, new family

2. Pectorals set low; teeth usually tricuspid

3. Aphanildee, nev family 
C. Motapterygold absent; notch between supraorbital process of the frontal and the sphenotic narrow or absent; lachrymal wide; mesethmoid ossified and composed of double laminae; parietals absent; vomer absent

1. Pectorals set high; median hypural bifld; notch between the supraorbital process of the frontal and sphenotic absent; jaws nonprotrusible

4. Oryziat1dae, new fantily.

2. Pectorals set low median hypurel fan-shaped with only a slight indication of division; notch between the supraorbital process of the frontal and the sphenotic wides jaws protrusible

5. Orestiadidae, new Pantly.

D. Metapterygoid absent; vomer edentulous; noteh between supraorbital process of the frontal and the sphenotic narrow; lachrymal wide; mesethmold ossiffed and composed of double laminae; parietals present; vomer present

6. Fundulidae, new fandly. 
II. Exoccipital condyles absent; supraoccipital extending backward to form a distinct dome-shaped strueture over the foramen magnumg neural arches of the first vertebre applied to the oceipital region and take part. In the articulation of the skull and the vertebral column; a distinct gap between the f1rst and the second vertebrae

7. Cyprinodont1dae, Cunther, 1866.

In the above gynopsis only a few diagnostic charecters have been mentioned, but additional differences between the varlous famllies have already been listed previously. 


\section{CONCLUSIONS AND RECOMNENDATIONS}

1. Properly evaluated groups of osteological characterlstics constitute more dependable evidence of phyletic relationships among oviparous cyprinodont flshes than do single characters.

2. The forked nature of the posttemporal cannot be clted as characteristic of the order Cyprinodontiformes because this bone is unforked in many groups of cyprinodonts.

5. The distinguiahing characteristies of the suborder Poecilloidea need revision beeause the skeletal features thus far considered to be diagnostlc of this suborder are not applicable to all nembers of the group.

4. The absence of the metapterygoid cannot be regarded as a distingulshing character of the suborder Poecilloidea becauge the metapterygoid is invariably preaent in all the aplochellids exanined in this investigation.

5. The ovlparous eyprinodonts share a number of osteological characteristies in common and, taken as a whole, these characteristics substantiate the valldity of the group as a natural assemblage of rolated forms.

6. Phylogenitically, the Viviparous cyprinodonts may be a part of the orlparous cyprinodont assemblage and, therefore, it is recoumended that the use of superfandlies Cyprinodontoldae and Poecilloldae be abandoned pending the establishment of the relationahips 
between the viviparous and oviparous forms on the basis of characteristics other than the single eriterion of reproductive method.

7. Osteologleal cheracteristics and geographical distribution of the aplochellids strongly suggest that they are the most generallzed of the eyprinodonts.

8. The aplocheilids or a stock similar to them almost certainly represent the ancestral stock from which all other major groupe of both the oviparous and the Viviparoue cyprinodont fiahes have originated.

9. Aplocheilus of Aria, Rivulus of South and Central America, and probably Eplplatys of APrica appear to be the most generalized of the aploche1lida.

10. It 1s suggested that the eyprinodonts probably originated somewhere near the African border of the Tethys Sea which exdsts at present in remnant form as the Mediterranean Ses.

11. Except for cyprinodontids (famdly Cyprinodont1dae) which probably originated from fundulids (family Fundulidae), all other groups of oviparous cyprinodonts (families Aplocheilichthyldae, Aphand1dae, Oryziatidae, Orestiadidae, and Fundurldae) have ovolved from Aplochellidas or a atock sinflar to them.

12. As prevlously recognized, the family Cyprinodontidae Is a heterogeneous aasenblage containing at least seven and possibly eight distinct lines of evolution. Seven of thees Iines are separable from one another by a number of osteological characters and also by geographleal diatinetions. 
18. It is recommended that the fantly Cyprinodontidae, as previously understood, be reorganlsed into the following seven fantlleat Aploche1l1dae, new family.

Genera: Aploche1lus, Aphyosemion, Rivulua, Cynolebias, Austrofunculus, and Nothobranchius and possibly Epiplatys, Pachypenchax, Rachovia, Pterolebias, Trigonectes, Rivulichthys, Neofundulus, and Hubbsichthys which were not examined. Aploche1lichthyldae, new family.

Cenera: Aploche111chthys, Micropanchax, and Lamprichthys and poss1bly Bypsopanchax, Procatopus, Cynopanchax, and Plataplocheilus which were not examined. Aphant1dae, new family.

Genera: Aphanius, Aphantops, Anatol1chthys, and Kosswiglchthys.

Oryziatidae, new fantly.

Gemus: Oryzias.

Orest1ad1dae, new family

Cenus: Orest1as.

Fundurldae, new family.

Genera: Fundulus, Lucania, Adinta, Chriopeops, IeptoIucania, Empetrichthys, Crenichthys, Profundulus, and Valenc1a? (see 1tem 16), and possibly Cuban1ehthys, and Oxyzygoneetes which were not examined. 
Cyprinodont1dae, Gunther, 1868.
Genera: Cyprinodon, Floridichthys, Jordanella, Qarmanella, and Cualac.

14. It Is recomenended that the fantly Aplochellichthyldae be divided into two subfantiles as follows:

Aplocheli1chthyinae, now subfandly.

Cenera: Aploche1lichthys, Cynopanchax, Plataploche1lus, and Micropanchax.

Procatopinae, new subfandly.

Cenera: Procatopus, Lamprichthys, Hypsopanchax, and Platypanchax.

15. The erection of a separate subfandly for the sole reception of Lamprichthys, chiefly on the basis of 1 ts etenoid scales and 1 ts numerous vertebrae, is untenable because such a treatant ignores the overwhelning similarities which this genus shares with such aploohellichthylans as Procatopus, Hypopanchex, and Platypanchex. Therefore, these four genera are placed into one subfandly, Procatopinae, of the fanily Aplochellichthyldae.

16. Lamprichthys tanganicanus appears to be a modified descendent of an aploche1l1chthys-11ke ancestor which perhaps gained access Into Lake Tanganylka when It was formed in the Rift Valley during the Pliocene.

17. Valencia is tentatively included in the fantly Fundulidee but It is auggested that further anatomical studies may show that this genus also represents a distinct phylotic line. Osteologically, Valencla resembles Profundulus more closely than 1t does other fundullds 
and both of these genera have been shown to be generalized primitive types. Therefore, it is suggested that some widespread ancestral stock, structurally resembling the widely distributed aplochellids of today, entered the Iresh waters of Central America and Span to later produce in those areas Profundulus and Valencis respectively.

18. Within the family Fundulidae two, and possibly three, evolutionary lines are apparent on the basis of osteological characteristies. Therefore, on further study, it may be possible to subdivide the family Fundulidae into three groups as follows:

Group 1 consisting of such geners as Profundulus, Empetrichthys, and Crenichthys.

Oroup 2 consisting of such genera as Fundulus and Adinta.

Group 8 consisting of such geners as Lucania, Chriopeops, and Leptolucania.

19. Due to the close resemblance of Central American genus Profundulus and the Death Valley genera Bmpetriehthys and Crenichthys, and the possibllity that fossil cyprinodonts known from the Middle Pliosene of Kansas may belong to Profundulus rather than to Fundulus, It is coneluded that Profundrilus, or a stock similar to 1t, was distributed from the Mexican Plateau to Death Valley at least in the Middle Plocene or perhaps earlier. This stock differentlated on the one hand Into such elosely related genera as Profundulus, Empetrichthys, and Crenichthys, and on the other into Fundulus. From Fundulus were derived two stocks: 
(a) Cyprinodon and its allies of the famlily Cyprinodontidae, and

(b) the Adinta-Iucania group of the family Fundulidae.

20. Lucania perva, Chrlopeops goodel (-Lucania goodel of of several recent authors) and Leptolucania onnata are closely related genera and it is suggested that Lucania parva differentiated in Morida to form two strictly fresh water specles, Chriopeops goodes and Leptolucania onmata.

21. Although the foregoing phyletic trends are apparent from this study, a more exhaustive study is recommended to determine the precise relationships of various genera of Group III (famlly Fundulidae). More information is needed concerning the fossil record, a more thorough coverage of representative specles, especially of the genera Tundulus and Profundulus, is necessary, and for all forms, more date are required on the comparative osteology, embryology, and anatomy of the soft parts.

22. A number of new osteological characters have been found to distinguish the two genera Bmpetrichthys and Crenichthys and It is shown that the use of the eplpleurals to distingulsh these two geners is not applicable.

23. Although showing superficial resemblances, the New World genera with tricuspid teeth (family Cyprinodontidae) and the Old World genera with tricuspld or unicuspld teeth (fandly Aphanildae) are not directly related because they differ in many fundamental osteological 
characteristics. Their superfleial resemblances are to be intarpreted as a result of parallel evolution.

24. New World genus Orestias (family Orestiadidae) and the 01d World genus Oryzias (Pamily Orysiatidae) are unique among cyprinodonts in lacking a vomer. Evidently the vomer has been lost independentily in each of these genera and, therefore, this character cannot be used to show any direct relationship between them.

25. The dendrogram constructed to show relationships of all the families of eyprinodonts, both ovfparous and VIviparous, is an arrangement which must remein tentative until all the familles have been analyzed on the basis of dependable and comparable assemblages of characteriatics.

28. In the course of osteological studies of cyprinodont I1shes by prevlous workers, several errors have accumulated for varlous reasons. Corrections of these errors are as follows:

(a) It was understood that the eyprinodonts had a circular, scale-like, ossified mesethmoid composed of double laminae as found in Valencia, Orsstias, Oryzias, and the fundulids. A aecond type, entirely cartilaginous, is present, however, in aploche1lids, aplochelliehthyians, and Aphanids.

(b) The suborder Poecilioidea has been chardicierized by the absence of metapterygoid and the ankylosed nature of the pelatine and the pterygoid. The metepterygoid 1s present, hovever, in Aplochellus, Aphyosemion, Rivulus, Cynolebias, Austrofundulus, and Nothobranchius, and the 
palatine and the pterygoid are distinct in all the eyprinodonts exandned in this study.

(c) It was understood that the aploche1l1ds Invarlably posseased parietels, but these bones are absent in Nothobranchius and Indistinct in Austrofundulus and Aphyosemion. The parietals are, however, present in Rivalus and Aploche1lus.

27. In this study a number of previously unreported osteological attributes have been diseovered for the oviparous cyprinodonts and of these additions several, considered of significance in determining the phylogenetic relationships, are listed below:

(a) The basisphenold is absent in all the eyprinodonts exarined in this study.

(b) The eplpleurals are attached directly to the neural arches of the first vertebra because this vertebra lacks both mibs and transverse processes.

(c) The postorbital is very small in all aplochell1ds (except Aploche1lus) and in Orestias; in all other cyprinodonts included in this study it is well developed.

(d) Two arrangements of the supraocelpital bone have been found in this study: In eyprinodont1ds (fandly Cyprinodontidae) the supraoccipital extends posteriorly and forms a prominent dome-shaped structure over the foramen magnum, but in all other groups (familles: Aplocheil1dae, 
Aplocheil1chthyldae, Aphanlidae, Orestiadidae, Oryziatidae, and Fundulidae) the supraoceipltal stops short of reachIng the foramen magnim and, consequently, takes no part in Its formation.

(e) The exoccipital condyles are absent in the fandly Cyprinodontidae; in all other fandlles of oviperous cyprinodonts these condyles are well developed.

(f) In the fandly Cyprinodontidae the akull axtioulates with the vertebral column by the besioccipital condyle and the neural arches of the flrat vertebra; in all other families of oviparous cyprinodonts the articulation is by the basioccipital and the exoceipltal condyles and the neural arches take no part in the articulation.

(g) The number of branchiostegal rays in the several genere examined in this study varles from three to six.

(h) In the fartily Aplochellidae the hypohyal on each side is represented by two bony pieces whereas in all the other families of oviparous cyprinodonts it is composed of a single piece.

(1) In Foridiehthys carpio the first pharyngobranchial ia ossifled and possesses two rows of confeal teeth; in all other cyprinodonts excmined in this study, this element is cartilaginous and edentulous.

(j) In aplocheilids the third and fourth pharyngobranchtals are distinctly separate. 
(k) In aplochellids and Oryzias there are three ossifled bastbranchtelv.

(1) The transverse processes of the precaudal vertebrae are short and eup-shaped in the famfly Cyprinodontidae; in all the other families of oriparous egprinodonts they are elongated.

(n) Median hypural variea from a median fan-shaped element to a bifld or a trifid element.

(n) Three types of prexygapophyses are present in the ovlparous eyprinodonts.

(o) Hasmal canals are narrow in the families Cyprinodontidae and Aphanifidaes moderetely wide in the famillies Aplochellidae, Fundulidae, Oryziatidae, Orestiadidae, and in Valencias and very wide in the family Aplocheiliehthyldae.

(p) The supraeleithrum is absent in Leptolucanias in all other ovlparous eyprinodonts examined during this study 1t is present.

(q) The spece between coracoid and cleithrum is very wide In the fanilies Aplocheilichthyldae, Aplochellidae and Oryziatidae; in all the other oviparous cyprinodont families it is narrow.

28. It 1s recomended that the fossil eyprinodonts be reexarined with special reference to such osteological characters as 
the metapterygoid, the vomer, the basibranchials, the branchiostegals, the premadillary processes, the parietals, the oupraorbital processes, the exocelpital condyles, the first vertebra, the transverae processes, the prezygapophyses, and the hypurals, all of which are important in deciphering the true relationships of the fossil forms.

29. The loss of various bony elements and the modifications of others is a conspleuous feature in the evolutionary trends of the oviparous cyprinodonts. 
EXPLANATION OF ABBREVIATIONS USED IN FIGURES

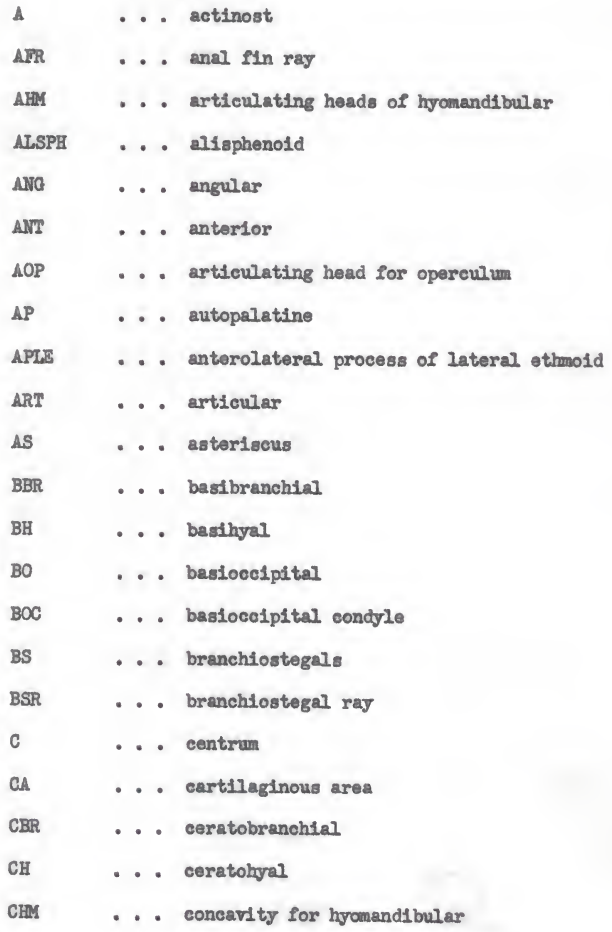




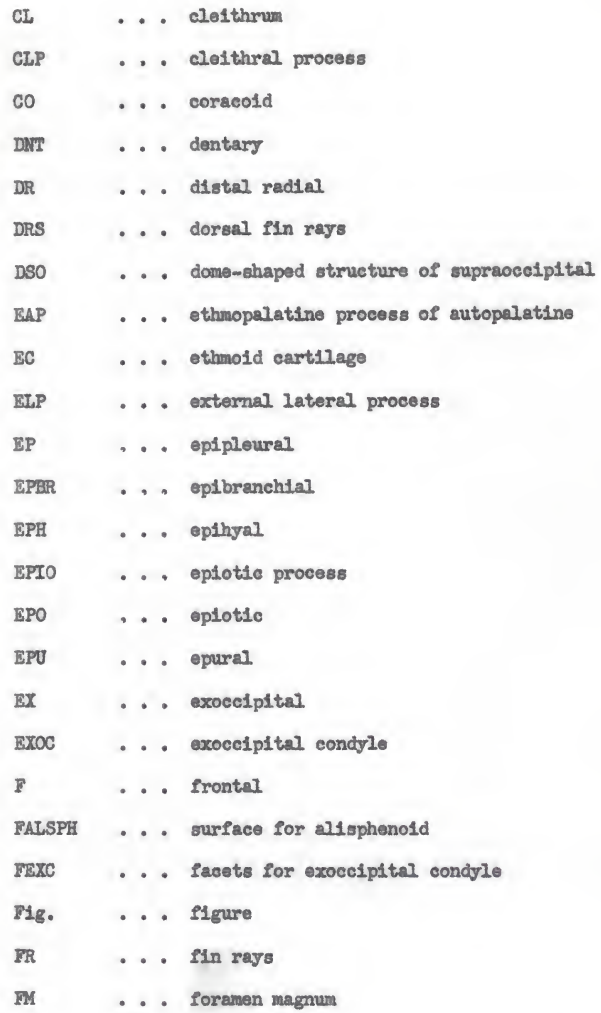




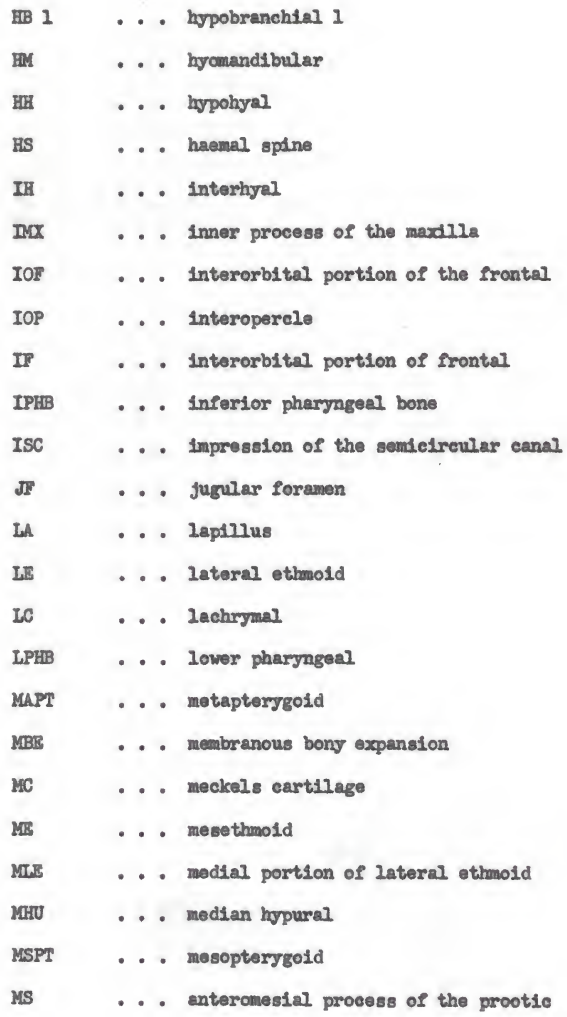




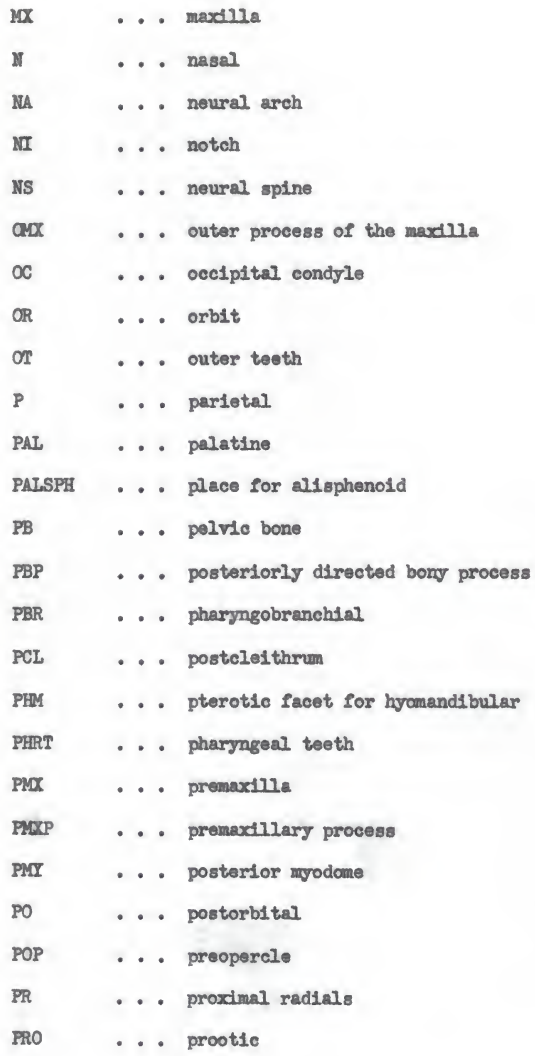




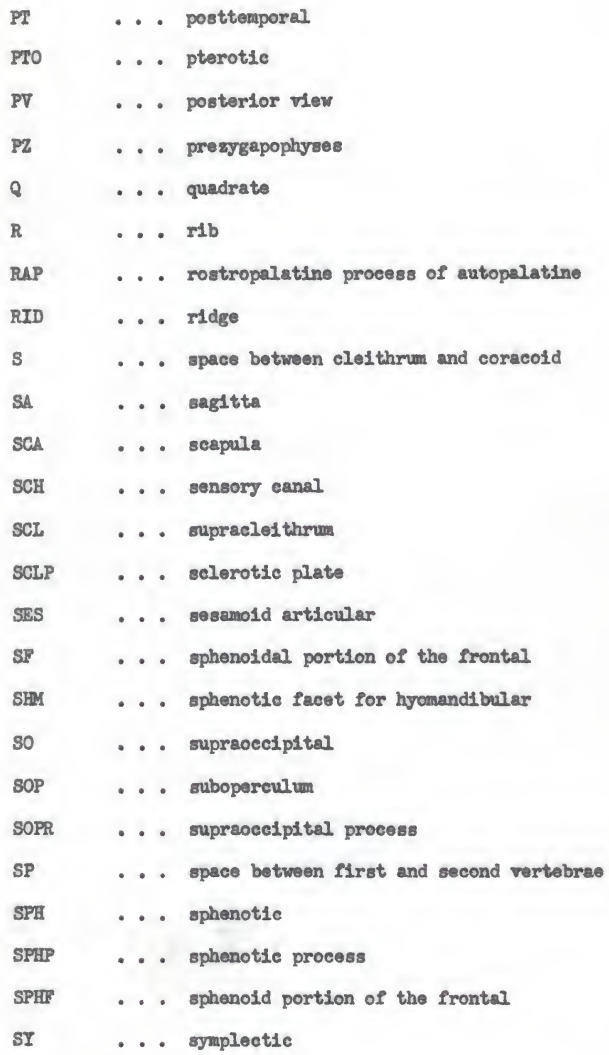




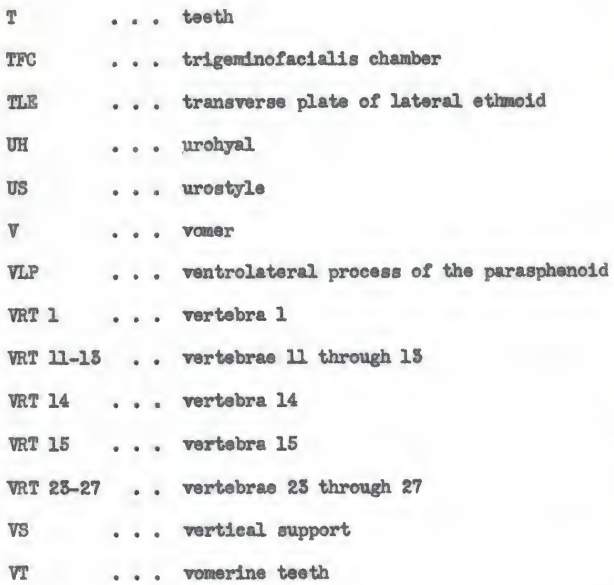


FIGUPES 


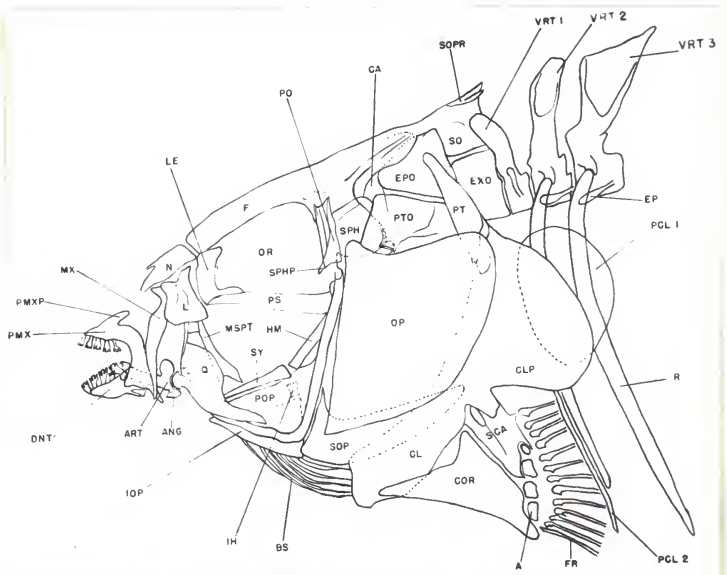

Fig. 1.--Cyprinodon V. varlegatus: head skeleton (lateral vlew). 


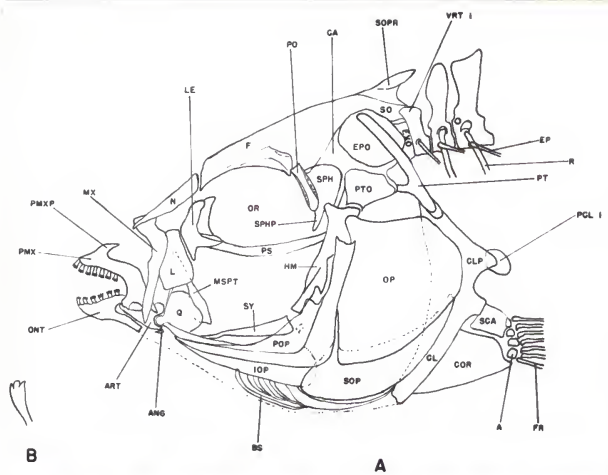

Fig. 2.--Cualac tessellatus A, head skeleton (lateral Vlew); B, single tooth.
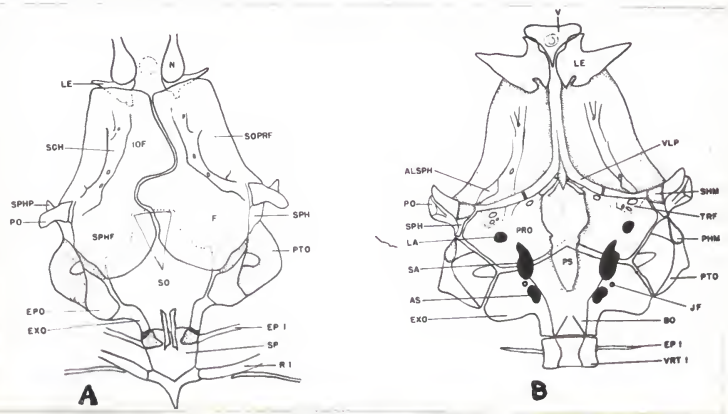

F1g. 8.--gyprinodon v. varlegatus, sirulls A, dorsal views

B, ventral view. 


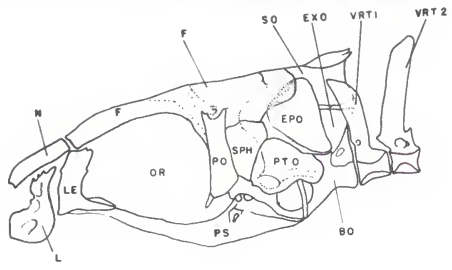

B

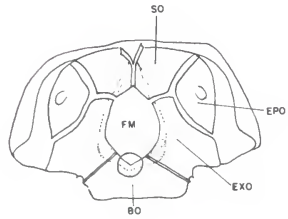

A

FIg. 4.--Cyprinodon V. varlegatus, skull: A, posterior VIew; B, side view. 


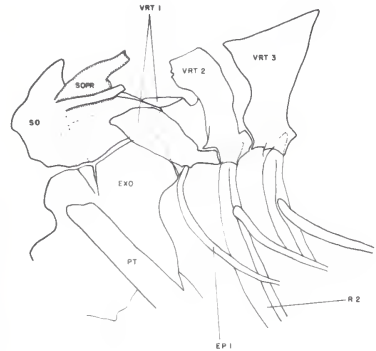

A

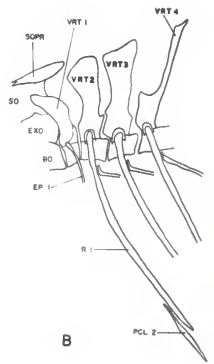

Mig. 5,-Decip1tal region and first three vertebraes A, Cyprinodon Y. varlegatus; B, Cualac tessellatus. 


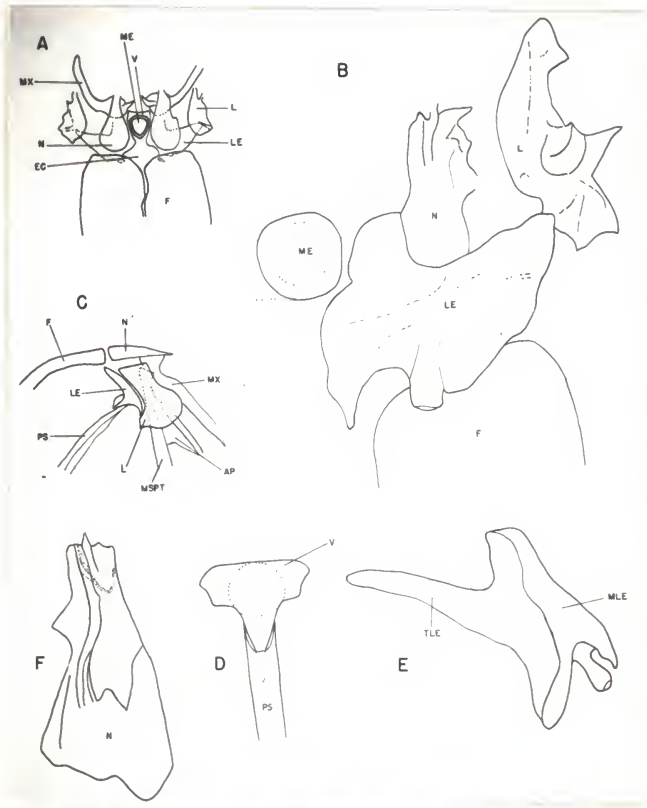

Fig. 6.--Cyprinodon v. variegatust A, ethmoid region (dorsal VIew) \& B, ethmoid rogion (Inner V1ev); C, ethmold region (side view), $D$, vomer and portion of parasphenold (ventral vlew) 3 , nasal (dorsal view). 

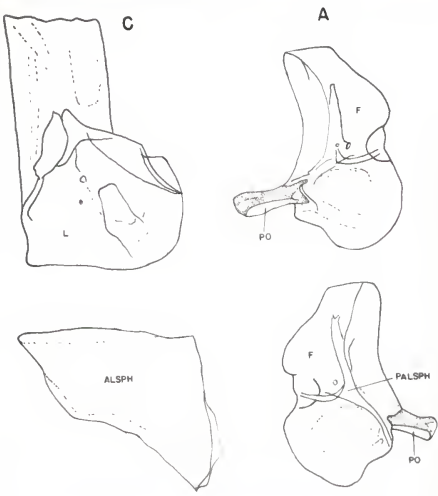

D

B

Fig. 7.--Cyprinodon v. varlegatus, orbitotemporal reglon: A, frontal and postorbital (dorsal vew) 3 , frontal and postorbitel (ventral vlew); C, lachrywal; D, als sphenoid. 


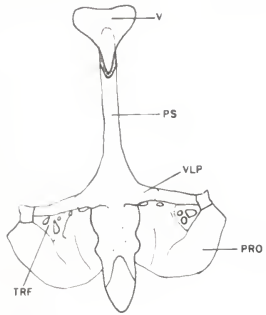

B

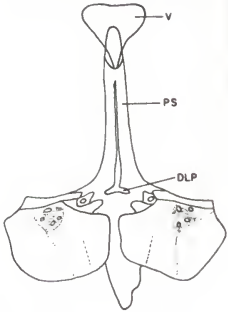

A

Fig. 8.--Cyporinodon 7 . variegatus, parasphenold, prootsle, and vomer: $A$, inner views B, ventral vew. 

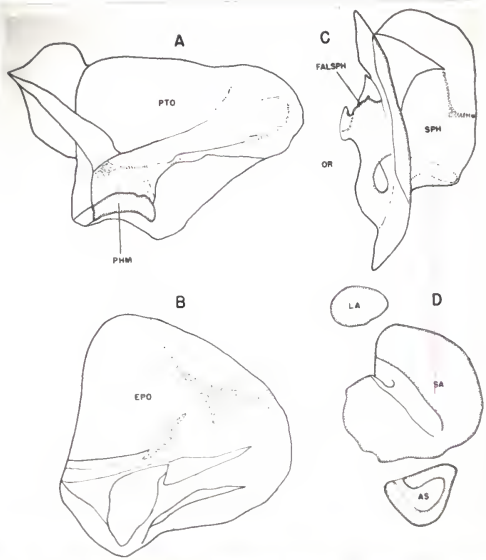

Fig. 9.--Cyprinodon V. varlegatus, ot1c reglons A, pterotics B, eplotie; C, sphenotic; D, otoliths. 

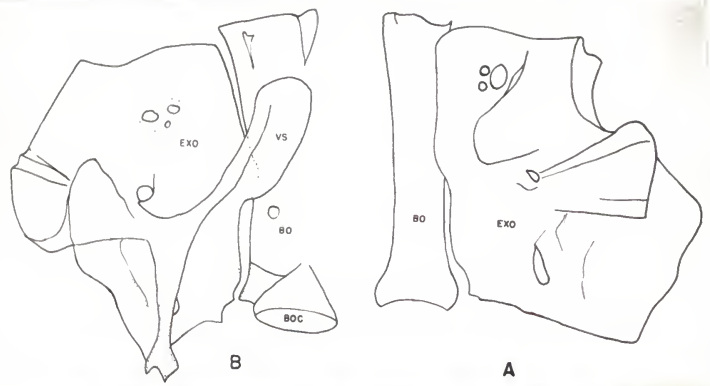

A

Mg. 10.-Cyorinodon v. variegatus, exocelpltal and basioceipital: $A$, ventral views $B$, inner view. 

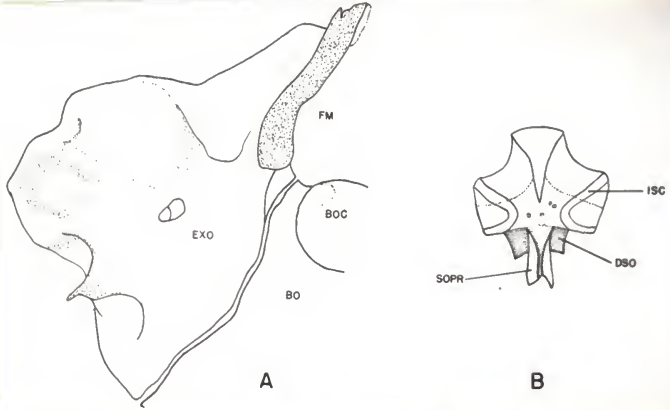

Fig. 11.-Cyrginodon I. variegatus: A, exocelpital and basioccipital (posterior view) B, supraoceipltal (doraal view).
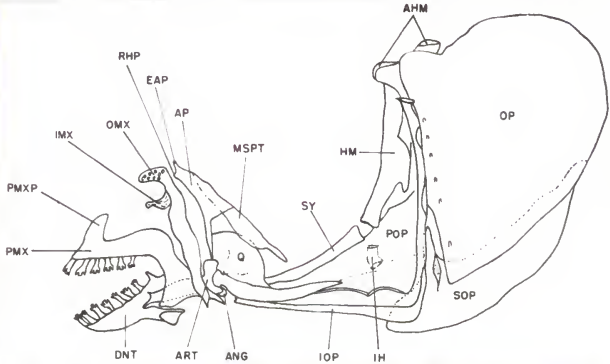

Mg. 12.-Cyprinodon $\mathbf{v}$. varlegatuss hyomandibular, sympleetic, mandibular areh, and opercular bones (outer vlew). 


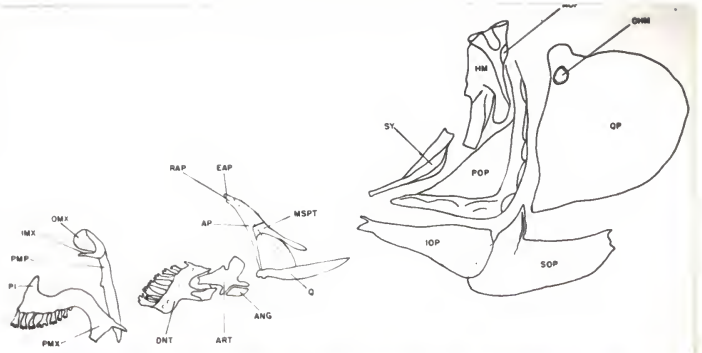

Hg. 13.--Cyprinodon V. varlegatus: hyomandibular, symplectie, mandibular arch, and opercular bones (nesial vew).

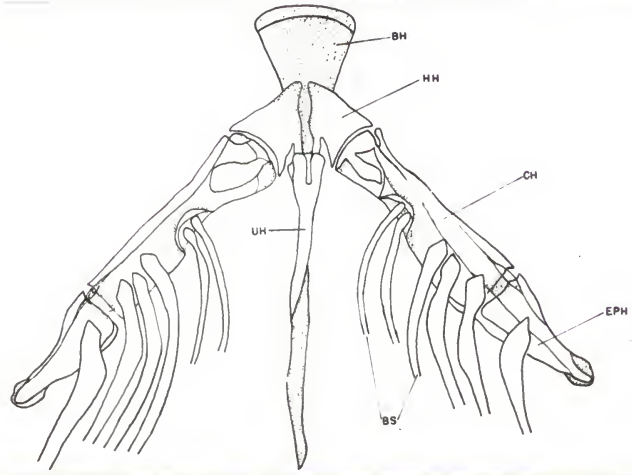

FIg. 14.--Gyprinodon I. varlegatuas hyold cormu, branchioategale and urohyal. 

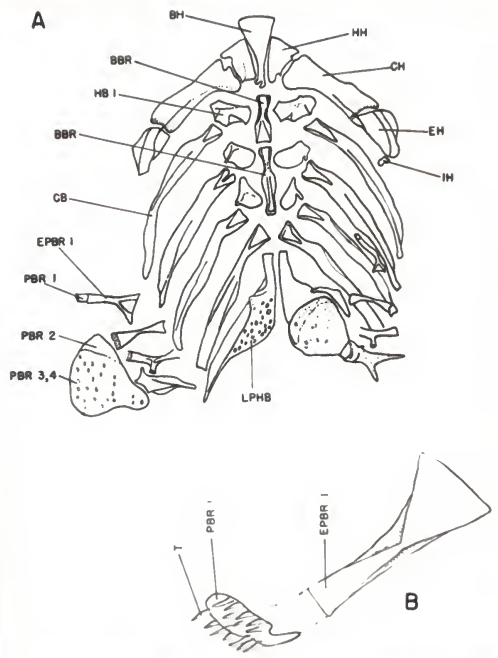

P18. 15.--A, branch1al arches of Gyprinodon I. variegatus; B, pharymgobranchial of Floridichthre c. earpio. 


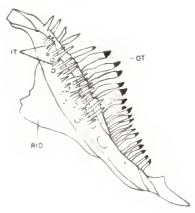

A

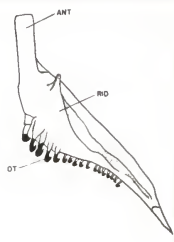

B

F1g. 16.--Gyprinodon $\mathbf{~}$. varlegatus, pharyngobranchials: A, inner views $B$, ventra

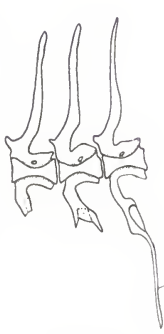

VRT $11-13$

A

Mis. 17.--Cyorinodon $\mathrm{v}$. varlegatust $A$, precaudal vertebraes 


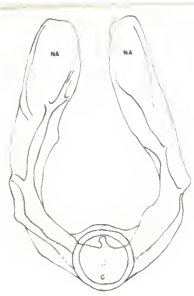

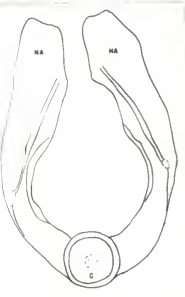

B

I8. 18.--Gypinodon v. varlegatus, NIrst vertebras A, anterior view; $B$, posterior view.

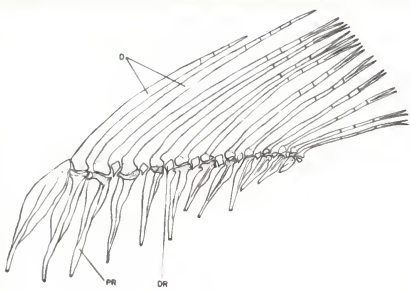

Fig. 18. - Gyprinodon I. varlegatus: dorsal sin. 


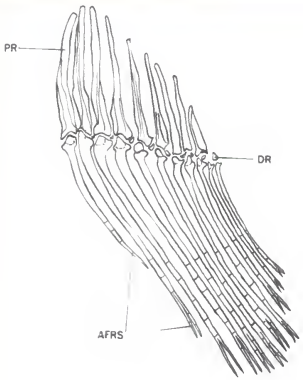

F18. 20.-Gyprinodon v. variegatust anal fln.

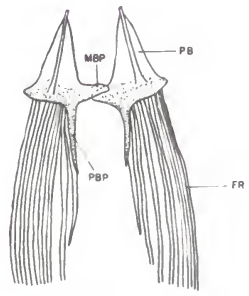

M8. 21.-Cyprinodon I. variegatusa pelvie bones and In rays. 


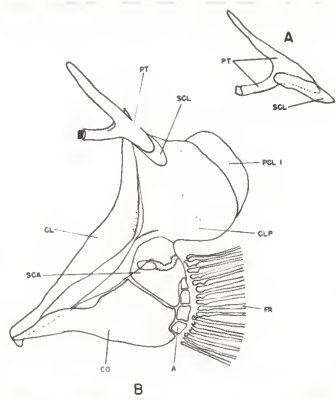

M1g. 22.--Cyprinodon v. variegatug! A, posttemporal and aupracleithming, pectoral gIrdle and IIn rays. 


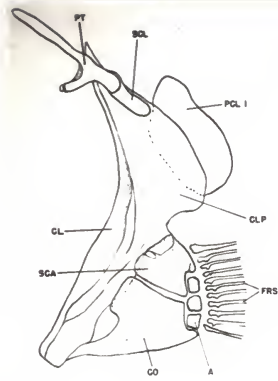

A

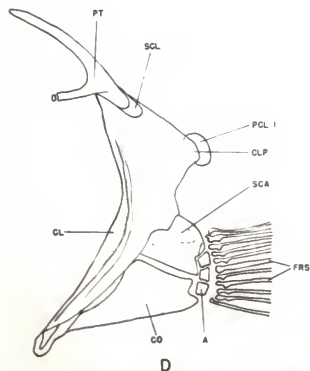

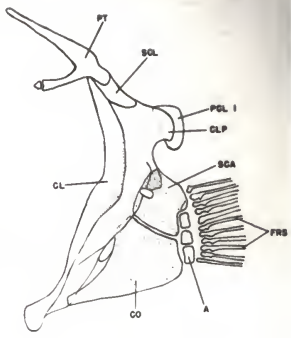

B

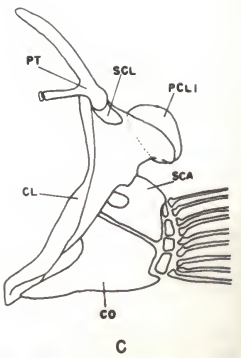

FIg. 25.-Peetoral girdle and fin rays of four apecies of egprinodont Plshes: A, Jordanella florldae; B, Garmanella pulohra; C, Foridichthys e. carpios D, Cuatac tessellatus. 


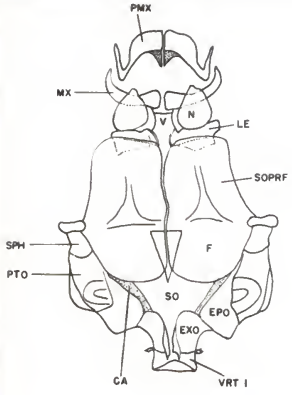

A

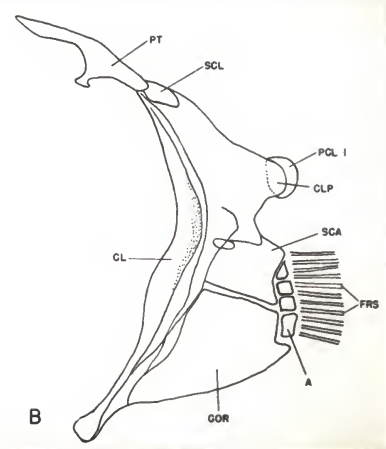

B

I1s. 24.--Aphanius gyprist A, skull (dorsal view),

B, pectoral girdle. 

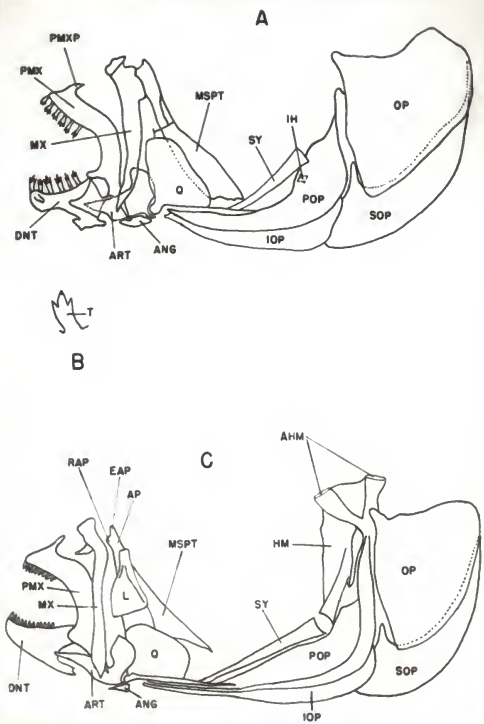

Mg. 25.-mh, hyonandibular, sympleet1e, mandibular arch and opereular bones of Aphanius crpris; B, single tooth; C, hyomandibular, symplectic, mandibular arch and opereular bones of Kosswl glehthre asquanatus. 


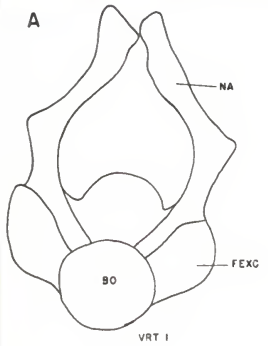

B
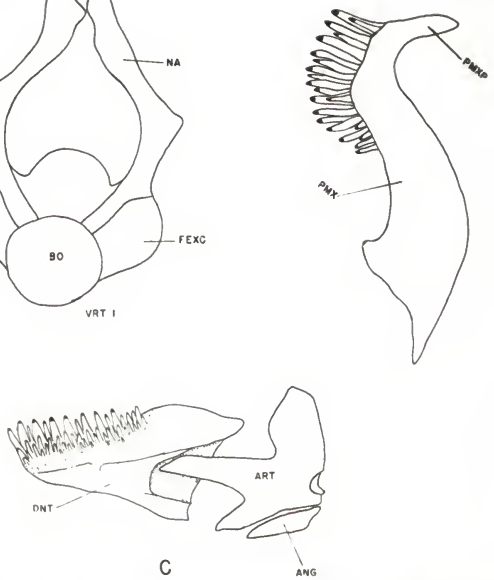

M1g. 26. - Kosswi giahthys agquamatus: 4 , first vertebrag $B$, premadilia; $C$, Iower Jaw. 


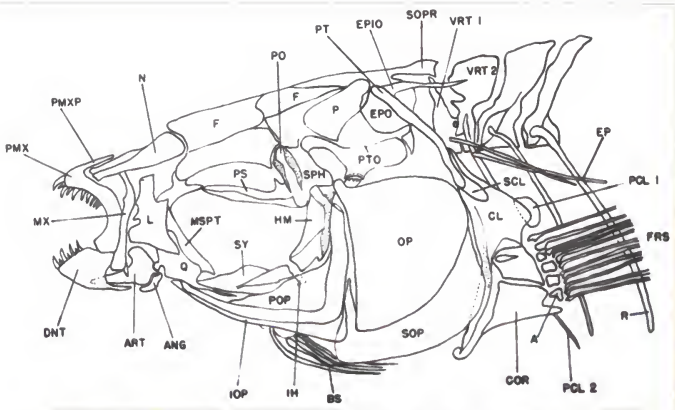

F8. 27.-Fundilus ehrysotus: head skeleton (lateral view).

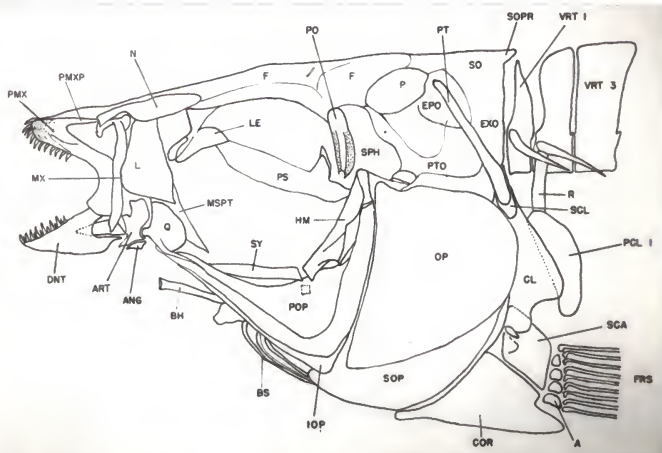

F18. 28.--Adinia xemia: head siceleton. 


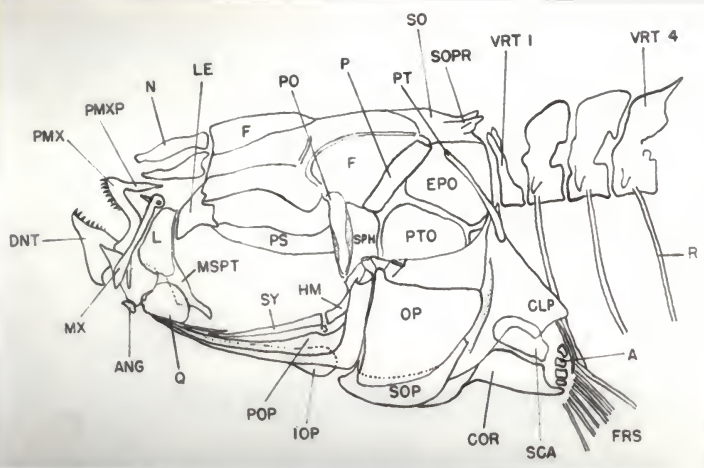

Fig. 29.-Leptoluean1a onnatas head skeleton (Lateral view).

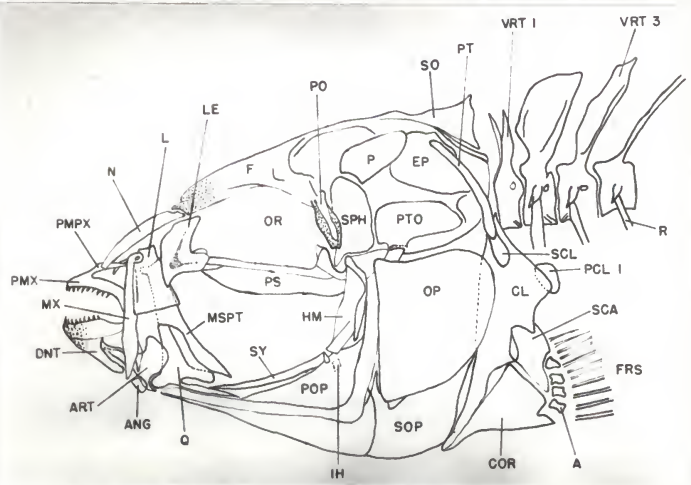

Fig. 30.--Lucania parras head skeleton (lateral view). 


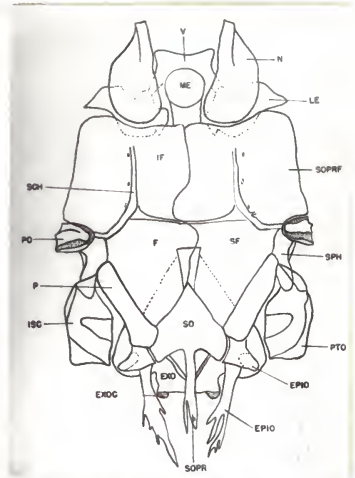

Fig. 31. - Fundulus chrysotus: skull (dorsal Vlew).

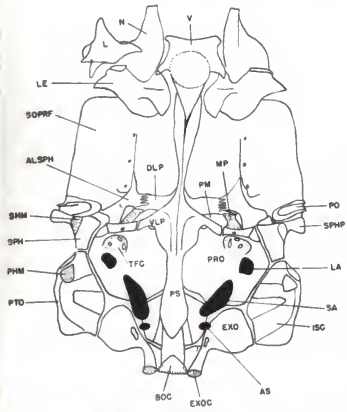

F18. 32. - Pundulus chrysotugs skwll (ventrel view). 


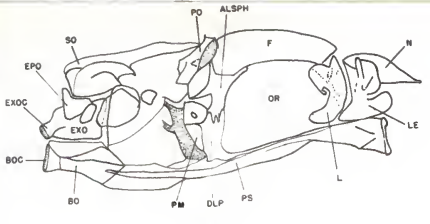

A

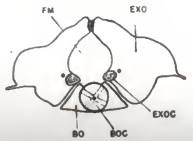

8

F1g. 85.--Fundulus chryootus, skull: A, lateral vlew; B, posterior vlew.

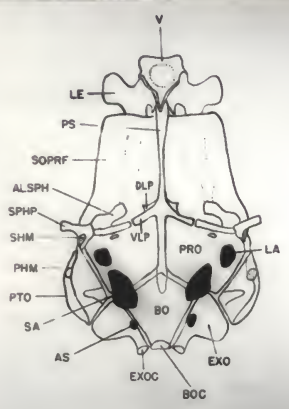

B

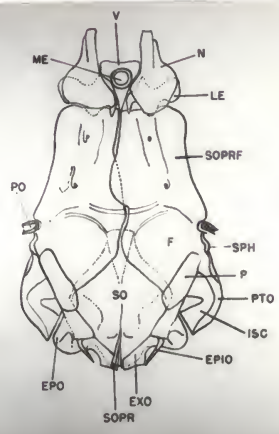

A

F1g. 34,--Lacania parva, skull: A, doreal views B, ventral view. 


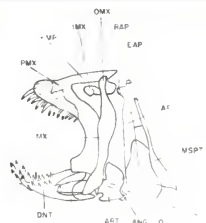

A

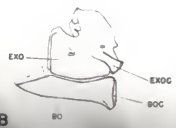

718. 35. -A, mendibular arch of hundulus chrysotuss B, baslocelpital and excocelpltal of pundulus chrysotus! C, vomer of Crontchthys batleys. 


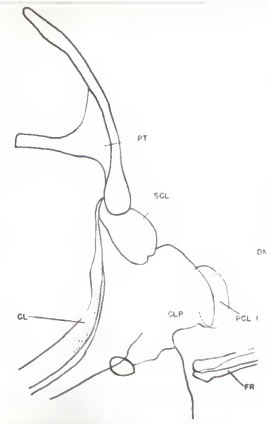

A

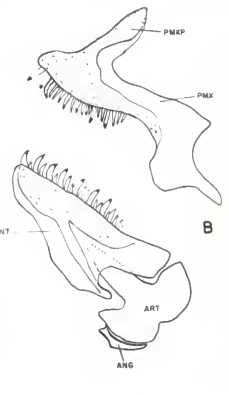

C

F18. 56.-Profundulus hildebrandi: A, portion of pectoral girdle; $B$, prenaxdile; C, Lower Jaw.

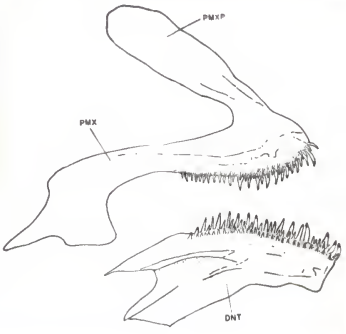

F18. 57.--Adinia xeniea: premadile and dentary. 


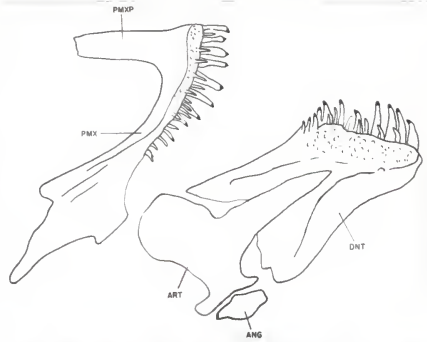

Fig. 38.- - Mmpetr1chthys latos: premaxilla and dentary.

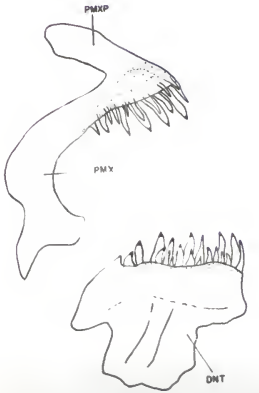

A

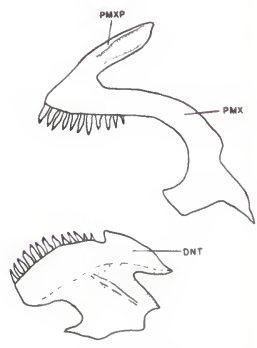

B

Mg. 59.--Premaxd lle and dentery: A, Chriopeops goode1;

B, Lucania parva. 

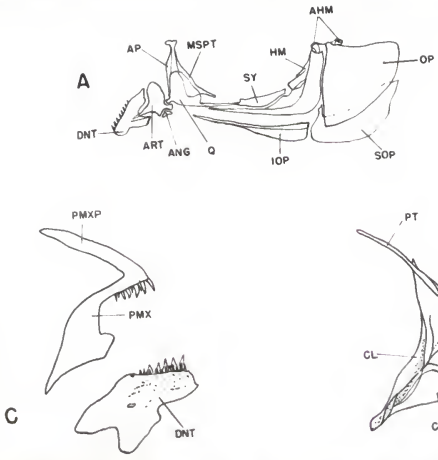

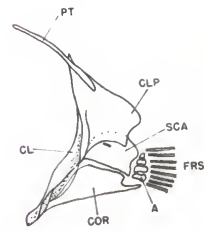

B

F18. 40,--Leptolueania omatas A, hyomandibular, symplectsc, and mandibular areh; $B$, pectoral girdle; $C$, premexdils and dentary. 


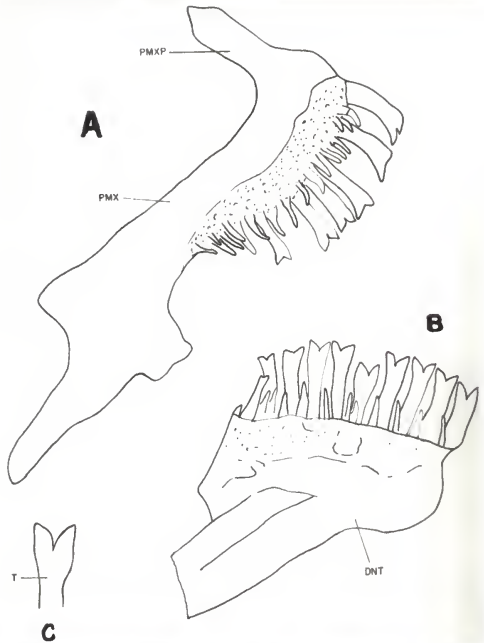

C, single tooth. - - 1 renichthys balleyl: A, prenadila, B, dentarys 


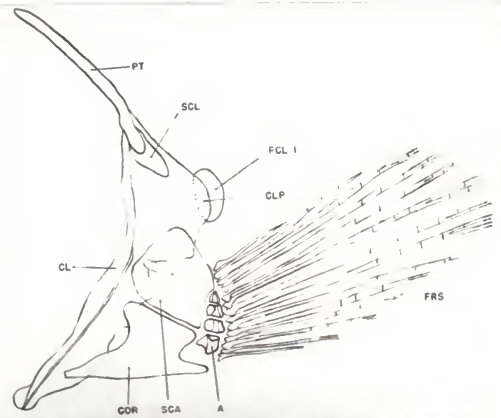

F1g. 42. - Pundulus chrysotus: pectorel glrdle.

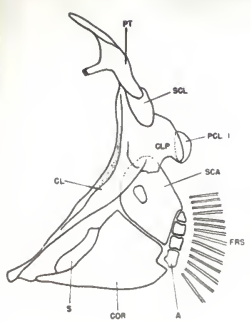

A

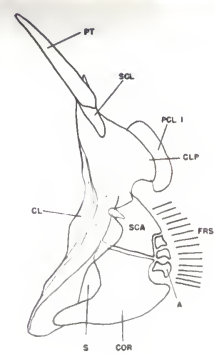

B
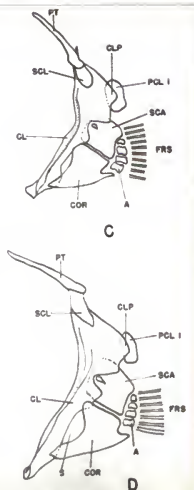

F1g. 43.--Pectoral girdle: A, Crantchthys baileyl; Adinta xenica; Lucania parva, and Chriopeops goodeI. 


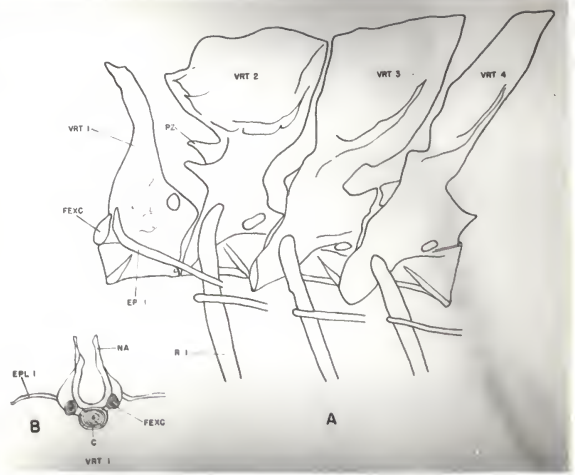

F1g. 44.-Dunchulus ehrysotuss A, first four vertebrae; B, flrst vertebre (anterior vieu). 


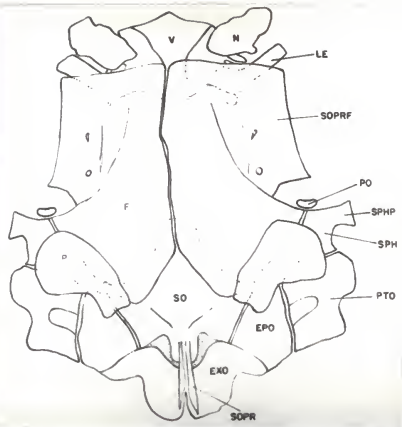

T18. 45.--Rivilus bondis skull (dorsel view).

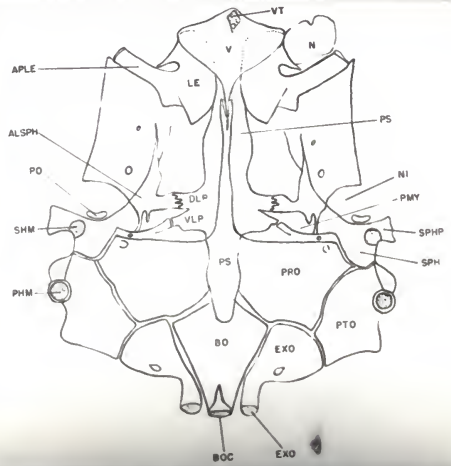

Mig. 46. - -Rivelus bondi: skull (ventral view). 


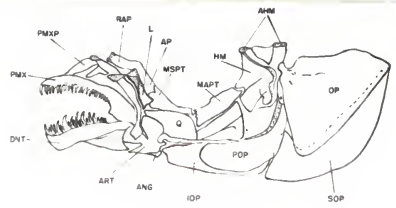

A

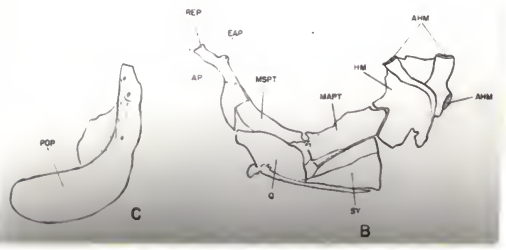

Fig. 47.--Rivulus bond1: A, hyomandibular, gyplect1e, mandibular arch and operculer bones; B, hyonandibular, syaplectle and sone bones of the mandibular arch; C, preopercle. 


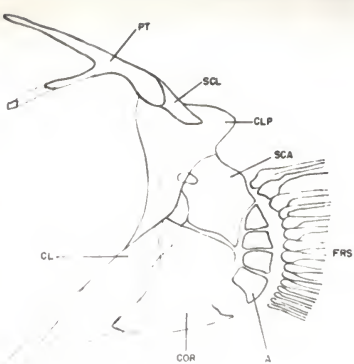

A

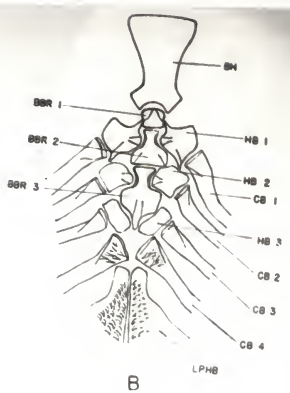

B
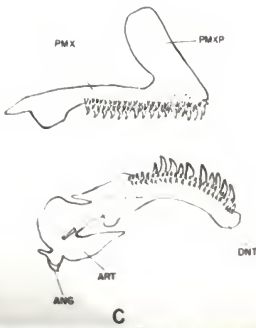

Mg. 48. - R1vulus bond1: A, pectoral glrdle; $\mathrm{B}$, portion of branchial skeletonj C, premardila and lower jav. 

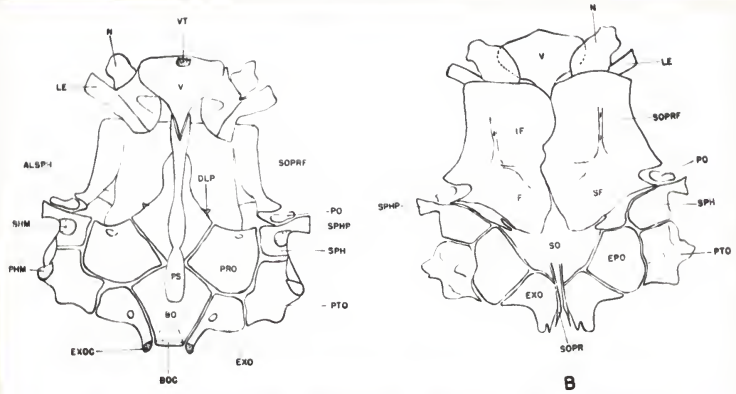

A

Pig. 49.-Aphyogemion ceoruleum, skull: A, ventral New; $B$, dorsel vlew.

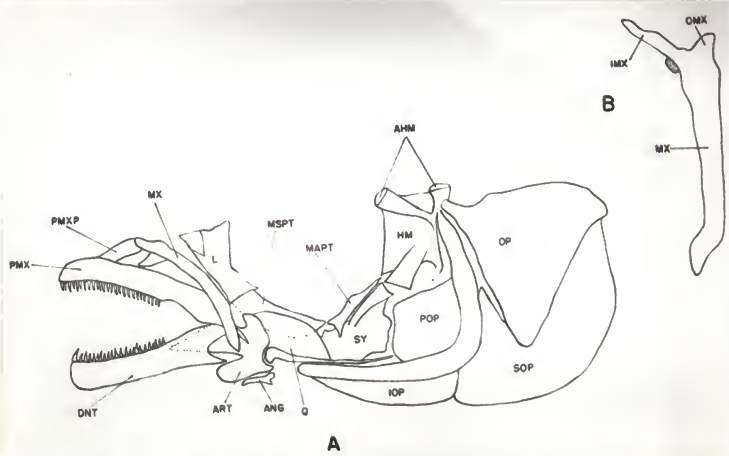

Fig. 50.--A phrosemion caerviloum: A, hyomandibular, oympleotic, mandibular areh and opereutar bones; $B$, maxdila. 


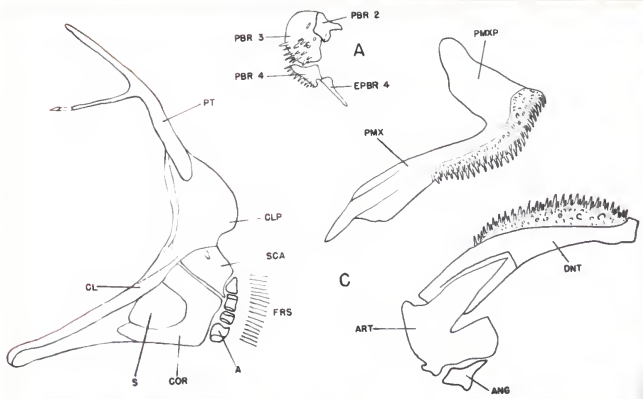

B

Fig. 51. - Aphyosention caerulouns A, pharyngobranchials $B$, pectoral girdle; C, premardilla and lower jaw.

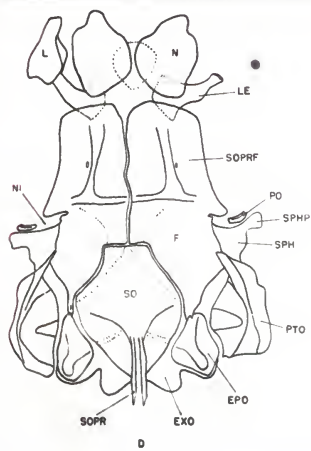

A

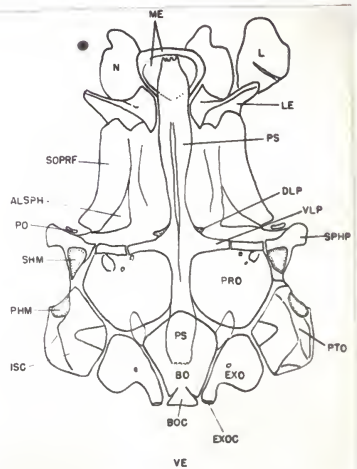

B

F1g. 52.--Osestias agassig11, skull: A, dorsal view

B, ventrel New. 


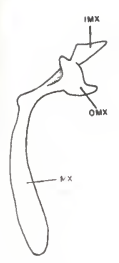

A

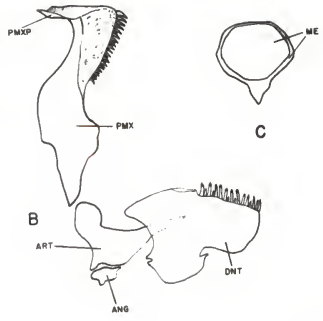

Fig. 53,--Orest1as agassizili, $A$, maxdlas $B$, prenardlles C, mesethmoid, $\dot{D}$, operele. 

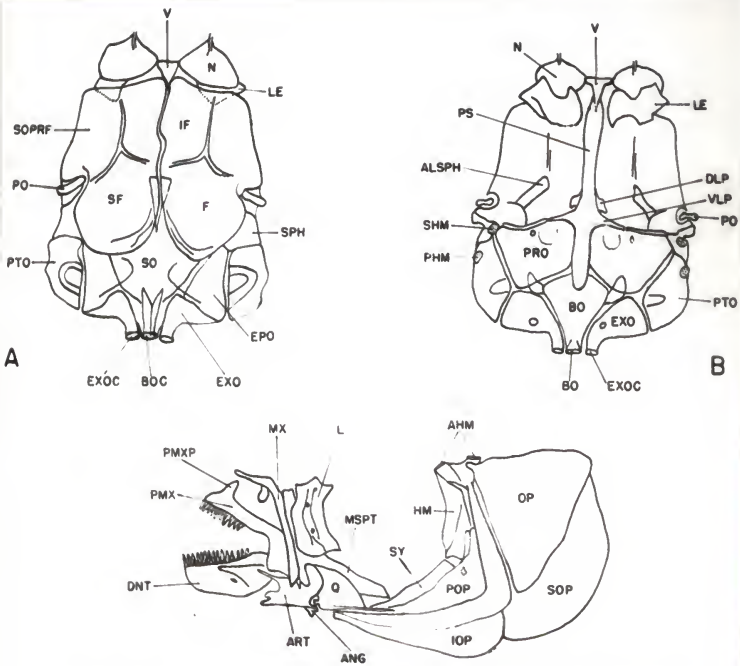

C

F1g. 54.-Aplocheill chthys katangaes A, skull (dorsal vlow) $B$, akull (ventral Fiew); C, hycmandiburar, symplectle, mandiburar areh and opercular bones. 


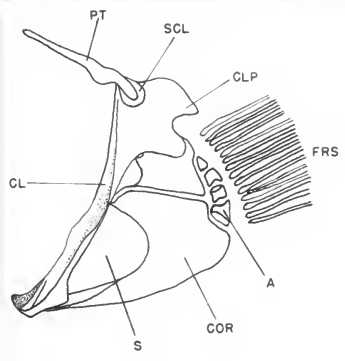

A

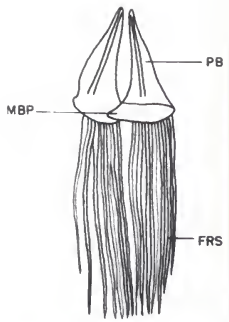

B

FIg. 55.--Aplochelllchthys katangae: A, pectoral girdle; $B$, pelvie bones and Rin rays. 

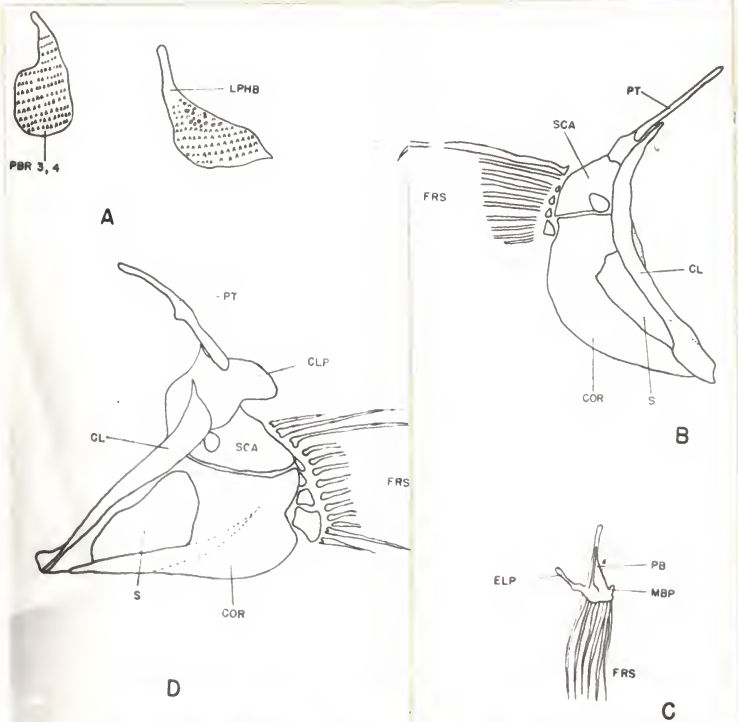

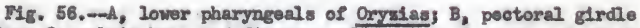
of Oryzias; C, pelvic bone and In raye of Orysias, $D$, pectoral girdie of Aplochoilus panchax. 


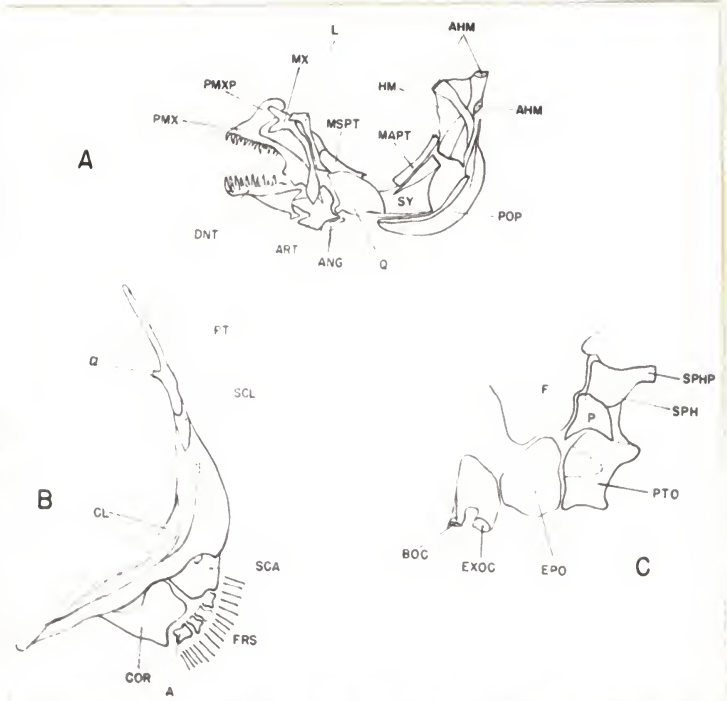

F1. 57.-Cynolobias hitef: A, iyomandibular, symplectic, mandibulas erroh and preoperaies Bf pecterel efrdle; $C$, portion of the skill. 


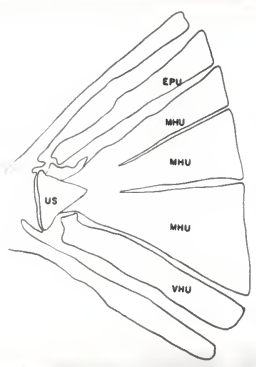

Mg. 58.--Aplochellus panchax: trLfld modlan hypural.

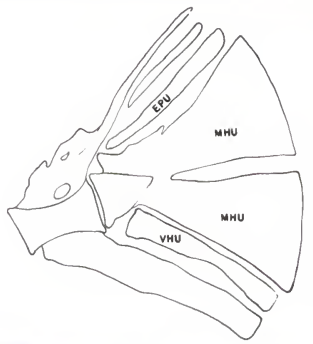

Mg. 58.--Orysies latipes: bifld median hypural. 
Ahl, Ermst. 1924. Zur Systenatik der altweltlichen Zahnkarpfen der Unterfamily Fundulinae. Zool. Anz., 40z 49-55.

Ahl, Brnst. 1928. Beltrage gur Systematik der afrikanischen Zahnkarpfen. Zoo1. Anz., 79: 118-123.

Aksiray, Feth1. 1952. Cenetieal contributions to the systematical relationship of Anatolian cyprinodont PLshes. Publ. Hydrobiol. Res. Inst. Univ. Istanbul, Ser. B, 1, Yasc. It 58-85, 29 Iigs., pls. 1-2.

Al11s, A. P. 1919. Myodone and trigemino-faclalls chamber of Plshes and corresponding cavitiss in higher vertebrates. Journ. Morph., 52: 207-326, pls. 1-4.

Balley, R. M. 1952. Proposed use of the plenary powars to destgnate a type species for the gems Heterandria Agassis, 1853 (class Ostelchthyes, order Cyprinodontida) in harmony with current usage. Bull. Zool. Nowencl., 6: 263-265.

Berg, Leo S. 1947. Classiflcation of Plshes both recent and fossil. Ann Arbor, Mehtgan: Bdvards Brothers, 1-517, $190 \mathrm{NIgs.}$

Bleeker, P. 1860. Fnumerat10 speciomm p1sc1um hucusque in Archipelago Ind1co observatum, stc. Aet. Soc. Se1. Indo-Neerl., $6(n, B, 2): 1-492$.

Bleeker, P. 1865. Atlas Ichthyologlque des Indes Orlentales Neerlandalse, Ansterdan, 3.

Boulenger, G. A. 1904. A symopsis of the cuborders and familles of teleostean 11shes. Amn. Mag. Mat. Hist., Serles 7, 13: $161-190$.

Chapman, Wilbert M. 1934. The osteology of the haplomis IIsh Noverubra hubbsi Schultz with comparative notes on related species. Journ. Norph., 56 (2): $571-405,8$ flgs.

Clothelr, Charles R. 1950. A key to some Southern Callfornian Plshes based on vertabral charecters. Calf. Div. Mish and Garse, Fish Bull. 79: 1-85, 21 Plgs., pls. 1-23.

Cope, B. D. 1891. On sane new 11shes from South Dakota. Amer. Nat., 25: 654 . 
Davls, Dwight D., and U. R. Gore. 1936. Clearing and staining skeletons of mall vertebrates. Fleld kns. Nat. Hist. Teeh. Ser., No. 4t 1-15, 5 figs.

Eastman, Charles R. 1917. Fossil fishes in the collection of the United States National Museum. Proe. V. S. Nat. Mus., 52. 235-304, 9 Plgs., pls. 1-23.

B1genmann, C. H. 1920. On the genere Orest1es and Bnpetrichthys. Copeia, No. 89: 103-106, 1 11g.

Eigermann, C. H., and W. R. Allen. 1942. Fishes of Western South America. Untv. of Kentuckg, $\mathbf{x v}+429 \mathrm{pp}$.

Bvans, Howard E. 1948. Cleaming and staining amall vertebrates, In toto, for domonstrating osaifleation. Turtox News, 26 (2): 42-47, 5 f1ga.

Fowler, H. W. 1916. Notes on Plshes of the orders Haplomi and Mierocyprint. Proe. Mead. Nat. Se1. Phila., 68: 415-459, 5 flgs.

Frost, 0. Allen. 1926. A comparative study of the otollths of the Neopterygian Plshes (continued). Orders Haploni, Heterond, Inomi, Iyomerl, Lypostonides, Salmopereae, Synentognath1, Microcyprint, Solenichthyes. Ann. Mag. Mat, Hiat., Series 9, 18: 465-48R.

Q111, Theodore, 1893. Famtlies and subfamilies of Nishes. Mem. Mat. Acad. Se1., 6: 127-158.

Garman, Samuel. 1895. The cyprinodonts. Men. Mus. Comp. Zoology., Harvard Coll., 19 (1): 1-179, pls. 1-12.

G111, Theodore. 1872. Arrangement of the familles of Plahes. Smithson. Kiscell. Collections. Sulthson. Institution, Washington, 2478 $x \mathrm{lv1}+49 \mathrm{pp}$.

Gilbert, Charles H. 1893. Report on the Plshes of the Death Valley expedition collected in Southern Callfornta and Nevada in 1891, with desoription of new species. N. Amer. Pauna, 7. 229-234, pla. V-VI.

Goodrich, B. S. 1958. Studies on the structure and development of vertebrates (Reprint of 1930 od.). New York: Dover Publ. Ine., ixdx $+837 \mathrm{pp}$.

Cordon, Myron, and Donn E. Rosen. 1951. A new flsh of the genus Cambusia from southern Veracruz, Mexdco, wth a discussion of tribe Gambusitint Hubbs. Zoologica, 36 (4): 267-272. 
Gunther, Albert C. I. O. 1866. Catalogue of the Ilshes in the British Mugeum. London, $6: \mathbf{x v}+568 \mathrm{pp}$.

Gunther, Albert C. I. Q. 1880. An Introduction to the atudy of Plshes. Bdinburgh: Adan and Charles Black, xvl + 720 pp., 321 e1gs.

Hibbard, Claude W., and Davld H. Dunkle. 1942. A new specles of cyprinodontid Nish fron the middle Pllocene of Kansas. Unlv. Kansas Publ., State Ceol. Surv. Kansas, Bull. 41: 270-276, pl. 1.

Hoedeman, J. J., and F. J. Bronner. 1951. De Orde van de Tandkarpertjes. VI. Cyprinodontifornes Berg, 1940. Het Aquarium, No. It 1-8, 5 flgs.

Hoodeman, J. J. 1954. Aquariumvissen-encyelopsedie. Amsterdam: U1tgeveris De Bezige B1f, 1-527, 355 Nigs.

Howell-Rivero, I., and Carl L. Hubbs. 1986. Studies of the Ilshes of the order Cyprinodontes. XV. The characters and relationahlps of Murcipenis huberi and Alfaro cuitratus. Occ. Papers Mus. Zool. Univ. Moh. No. 358 I-11.

Howell-Rivero, L., and I. R. RIvas. 1944. Studies of cyprinodont fishes. Two new genera of the tribe clrardinins from Cubs, Torreie, 12: $8-19$.

Hubbs, Carl L. 1919. A comparative study of the bones forming the opercular serles of Ilahes. Journ. Morph., 83: 61-71.

Hubbs, Carl L. 1924. Studies of the flshes of the order Cyprinocontes. Mise. Publ. Mus. Zool. Univ. Mich., 13: 1-51, pls. I-IV.

Hubbs, Carl I. 1926. Studies of the flshes of the order Cyprinodontes. Mlsc. Publ. Mus. Zool. Univ. M1ch., 16: 1-86, pls. I-IV.

Hubbs, Carl I. 1982. Studies of the flehes of the order Cyprinodontes, XII. A new genus related to Empetrichthys. Oce. Papers Mus. Zool. Univ. Mich., 252: 1-5, pl. I.

Hubbs, Carl L. 1936. Fishes of the Iucatan Peninsula. Carnegle Inst. Washington Publ. 457: 157-287, pls. I-XV.

Hubbs, Carl L., and C. I. Turner. 1939. Studies of the flshes of the order Cyprinodontes. IVI. A revision of the Goodeidae. Mise. Publ. Mus, Zool. Univ. Mich., 42: 1-80, pls. I-V. 
Hubbs, Carl I. 1941. A new family of I1shes. Journ. Bombay Nat. B1st. Soe., Ind1a, 42: 446-447.

Hubbs, Carl L. 1950. Studies of eyprinodont Plshes. X. A new aubfanily frem Cuatemala, with etenold seales and a unilateral pectoral elasper. Mise. Publ. Mus. Zool. Untr. itich., 78 , 1-28, pls. 1-4, map 1.

Jordan, Davld Starr, and Barton Warren Ivermann. 1896. The Plshes of North and Middle Ameriea. Bull. U. S. Nat. Mus., 47, pt. $2: 1 x+1240$ pp.

Jorden, David Starp. 1925. A classiflestion of Mshes Including genera as far as known. Standord Univ. Publ. Blol. Sel., $8(2): 77-245, I-I X$.

Jordan, David Starx. 1924. Mocene Ilshes from southern California. Bull. Southern California Aead. Sc1., 25: 42-50, pls. I-I.

Jordan, David Starx. 1925. The fossil flshes of the Klocene of eouthern Callfornta, Stanford Univ. Publ. Blol. Sel., 4 (1): 1-51, pls, 1-21.

Jordan, Devid Starr, Barton Warren Bvermann, and Howard Walton Clark. 19\%0. Cheok 11st of the Plshes and Plshlike vertebrates of North and Middle Ameriea North of the Northern boundary of Veneruela and Columbia. Rept. U. S. Casm. F1sh., 1928, pt. 2: iv +670 pp.

Konuralp, Neriman. 1955. A study of the gonad morphology of Anatolian eyprinodonts. Rev. Tac. Sci. Univ. Iotanbul, Ser. B, Se1, Nat. 20(ร): 157-198.

Kosสwig, Curt. 1945. Uber Tethysrelikte in der turkischen Fauna. C. R. Ann. Arch. Soe. Turque Sc. Phyrs. Nat., 10: SO-47.

Kosswig, Curt, and Turuzan Sozer. 1945. Nouveaux cyprinodontides de I'Anatolle centrale. Rev. fac. sel. Univ. Istanbul, Ser. B, 10: 77-85, 4 IIgs.

Kulkarn1, C. V. 1940. On the systematio position, structural modifieations, bionomics and development of a renarikable new fandly of cyprinodont Plshes from the provinee of Bombay. Rec. Ind. Mus., 42: $579-425,20$ Rigs.

Kulkarnt, C. V. 1948. The osteology of Indian eyprinodonts. Part 1. Comparative study of the head skeleton of Aplochellus, Orysias and Horalchthys. Proe. Nat. Inst. Se1. India 14 (2): $65-119,25$ IIgs. 
Mayer, Ernst, 1958. Methods and Principles of Systenatic Zoology. New Iorks MeGraw-Hill, ix $+328 \mathrm{pp}$.

Meek, Seth Eugene. 1904. The fresh water flahes of Mexdco North of the Isthmus of Tehuantepec. Mleld Col. Mus. Publ. $93=(2001) 5,.1 \times 111$ + 252 pp., 72 flgs., pls. 1-17.

Miller, Robert R. 1945. Tour new species of fossil eyprinodont Plshes Irom Dastern Callfornia. Journ. Wash. Acad. Sel., 55: 515-521, 4 P1gs.

K1Iler, Robert R. 1948. The eyprinodont ILahes of the Death Valley system of Bastern Callfornia and Southwestern Nevada. Kise. Publ. Mus. Zool. Un1v. Kich., 68: 1-155, pla. I-XV, maps $1-3$.

Miller, Robert $R$. 1955. A systematic review of the Middle American Ilshes of the genus Profundulus. M1se. Publ. Mas. Zool. Univ. Kich., 92: 1-64, 6 IIgs., pls. I-IX, maps 1-3.

Miller, Robert R. 1956. A new genus and species of eyprinodontid flsh from San Luls Potos1, Yexdco, with remarks on the aubfanily Cyprinodontinae. Occ. Papers Mus. Zool. Univ. Mich., 581: 1-17, 2 Plgs., pls. I-II.

Myers, G. S. 1925. Results of some recent studies on the American kiliflahes. The F1ah Culturist, Phlladelphla, 4: 870-57.

Myers, A. S. 1927. An analysis of the genere of Neotropical k1111flshes allied to RIvulua. Ann. Mag. Nat. Hist., Ser. 9, 198 115-129.

Hyers, G. S. 1928a. The systenatic position of the Phallosteth1d Plahes, with diagnosis of a new genus fron Slan. Amer. Nus. Novit., 295: 1-12, 2 Plgs.

Myers, G. S. 1928b. Two new genere of Plshes. Copeis, 166: 7-8.

Hyers, G. S. 193. The primary groups of oviparous eyprinodont P1shes. Stan. Univ. Publ1. B101. Se1., 6 (5): 241-254.

Myers, Q. S. 1932. A new genus of funduitine eyprinodont Plshes from the Orinoco Basin, Venezuela. Proc. Biol. Soc, Washington, 45, 159-162.

Hyers, O. S. 1985. The genera of Indo-Malayan and African eyprinodont Ilshes related to Panchax and Nothobranchlus. Copeia, No. Is $180-185$. 
Hyers, O. S. 1955a. Four new freah water I1shes from Brazdl, Venezuela and Paraguay. Proc. Blol. Soc. Washington, 48: 7-13.

Myers, G. S. 1955b. An annotated list of the eyprinodont I1shes of Hispantola, with deseription of two new species. Zoologica, 10 (3): 301-516, 7 IIga.

Hyers, O. S. 1936. Report on the IIshes collected by H. C. Raven in Lake Tanganylka in 1920. Proc. 0 . S. Nat. Mus., 84: 1-15, pl. 1.

Wyers, O. S. 1938. Studies on the genera of eyprinodont 21shes. IIV. Aplochelliehthyse and 1ts relatives in Afriea. Copela, Mo. $3:$ $136-148$.

Wyers, O. S. 1942. Studies of South American fresh water Ilshes, 1. Stanford. Ieh. Bull., 2 (4): 89-114, 19 figs.

1vers, O. S. 1947. The Amazon and 1ts Plshes. Part III. Amazontan aquarlum Ilshes. Aquarium Journal $18(5), 7-15,82$.

Hyers, G. S. 1952. Annusl 12shes. Aquarium Journal, 23: 125-141.

Myers, G. S. 1958. Trends in the ovolution of tsleostean Plahes. Stan. Ich. Bull., 7 (3): 27-30.

NHkolakd1, G. V. 1954. Chastnala Ikhtiologla. Moseown State Publishing House, Soviet Scienee, 1-458, 312 IIgs.

Oztan, Nezhs. 1954. Cytologieal Investigation of the sexual differentiation in the hybrids of Anatollan cyprinodonts. Rev. Fae. Sei. UnIv. Istenbul, 18, Fase. 4: 245-280, 11 IIgs., ple. I-VII.

Phillips, J. B. 1942. 0steology of the sardine (Sardinops caerulea). Journ. Morph., 70 (5): 463-500, 25 flgs.

trpiem, H. 1908. In J. de Norgan, "Delegation en Perse," Ann. Hlst. Nat. Vol. 1.

Ramaswant, L. 8. 1945. The chondroeranivm of Gambusle (Gyprinodontes) with an account of the osteocrantiun of the aduIt. J. Mysore Oniv., 6B: 10-45, 5 I1gs., pls. I-III.

Ramaswami, L. S. 1946. I comparetive account of the skull of Gambusia, Oryzias, Aploche1lus and Xiphophorus

(Cyprinodontess Teleostomi). Spol12 Zeylan. Colombo, 24, pt. Is 181-192, 14 I1gs.

Regan, C. Tate. 1906-1908. Plsces. Blologla Central1-Americana, Iondon, $\operatorname{xod11}+208$ pp., pls. 1-26, maps 1-7. 
Regan, C. Tate. 1909. The classiflcation of teleostean Plahes. Ann. Nag. Nat. Hist., Series 8, 5:75-86.

Regan, C. Tate. 1911. The osteology and classlflcation of the teleostean P1shas of the order Microcyprint. Ann. Mag. Nat. Hst., Series 8, 7: 520-527, pl. VII.

Regan, C. Tate. 1915. A revision of the eyprinodont Plshes of the subfandly Poec1lilnae. Proc. Zool. Soc. London, 1913 (2): 977-1018, 11gs. 168-175, pls. 94-101.

Robertson, George K. 1943. Fundulus sternberg1, a Pliocene fish from Kansas. Journ. Palent., I7 (3): 305-307, pl. 52.

Rosen, D. E. 1952. A revision of the Plshes in the subfandly Alfarinae of the fandly Poecilildae. Zoologlea, 57 (3): 151-156.

Rosen, Donn E., and Hyron Gordon. 1958. Trunctional anatony and evolution of male genitalia in posellild flshes. Zoologlea, 38 (1): 1-47, 47 Ilgs., pla. I-IV.

$\downarrow_{S}$

Sauvage, E. 1874. BuIl. Soc. Hist. Nat. Toulouse, Vol. 8.

Schultz, leonard P. 1942. The fresh water flshes of Liberla. Proc. U. S. Nat. Mus., 92 (\$152): 801-548, pls. 55-36.

Sehultz, Leonard P. 1949. A Rurther contribution to the ichthyology of Venezuela. Proc. U. S. Nat. Mus., 99 (3235): 1-211,

20 I1gs., pls. 1-5.

Sozer, I. 1942. Contribution a Ia connalssance des eyprinodontides de la Turquie. Rev. Fac. Se1. Univ. Iatanbul, Ser. B, 7. $307-516$.

Starks, E. C. 1904. A symopsis of characters of some Plshes belongIng to the order Haplont. B10l. Bull., VII: 254-262.

Starks, B. 1926. Bones of the ethmold reglon of the Nish skull. Stanford Univ. Publ., Biol. Sel. 4i 159-358, 5 figs.

Steinitz, H. 1951. On the distribution and evolution of the eyprinodont fishes of the Moditerranean Region and the Near Bast. Bonn Zool. Beltr., Publ. $2(1-2)$ : 118-124, 1 map.

Sundra Ray. 1916. Notes on the freshwater Plshes of Madras. Ree. Ind. Mus., 128 249-294, pls. XXV-XXTX. 
Tchermavin, V. V. 1944. A revision of the subfamily Orestifnae. Proc. Zool. Soc. Lond. 114: 140-235, 27 IIgs.

Turner, C. L. 1953a. The unique nutritional organs in the enbryos of the top minnows of the Mexican Plateau. Science (n.s.) 77. 95-94.

Turner, C. L. 1935b. Nutritive processes in the embryos of the Goodeldae, Viviparous top minnowe of Mexdeo. Anat. Rec., 57: 77 (abstract).

Turner, C. L. 1955e, VIVlparlty superimposed upon ovoviviparity in the Coodeldie, a fandly of eyprinodont teleost flahes of the Nexdcan Plateau. Journ. Norph., 55, 207-251.

Turner, C. L. 1957. The trophotaeniae of the Goodeldae, a family of viviparous eyprinodont 11shes. Journ. Morph., 61: 495-523, pla. 1-4.

Weber, Max, and I. F. De Beaufort. 1923. The flshes of the IndoMalayan Archipelago. 4, Leyden.

White, Frrol Ivor. 1927. On a fosstl cyprinodont from Ecuador. Ann. Mag. Wat. Hst., Ser. 9, 20t 519-525, $1 \mathrm{Ng}$.

Waltzman, Stanley Howard. 1954. The osteology and the relationships of the South American characid Nishes of the subfanily Gasteropelecinae. Stan. Ichth. Bull., 4 (4), 213-263, 18 IIgs.

Woods, Loren P., and Robert $F$. Inger. 1957. The cave, apring, and swamp flshes of the fanily Amblyopsidae of central and eastern Inited States. Amer. Midland Nat., 58 (I), 232-256, 11 Plgs.

these references were not avaflable. 


\section{BIOGRAPHICAI SKETCH}

Ram Prakash Seth1 was born in Kot Mohammad Khan, District Amritsar, East Punjab, Ind1a, on March 19, 1930. He attended gramar and publle schools in Indla and was graduated fron Victoria IIgh School, Agra, in June, 1945.

In July, 1945, he entered Agra College, Agra, and obtalned his Bachelor of Sclence and Master of Sclence degrees in 1949, and 1951, respectively, from Agra University, Agra.

In 1951 he was appointed a lecturer in the Department of Zoology at Agre College and taught both graduate and undergraduate classes for IIve years before recelving a Fulbright Traval Grant to cone to the University of Florida, where he began his doctoral progran of study in September, 1957. He held graduate assistantships in the Department of B10log from September, 1957, through January, 1960.

He holds membership in the Soclety of SIgma XI, the American Society of Ichthyologists and Herpetologists, and the Academy of Zoology (India). 
Thls dissertation was prepared under the direction of the chatrman of the candidate's supervisory committee and has been approved by all members of the committee. It was submitted to the Dean of the College of Arts and Sclenees and to the Gracuate Councll and was approved as partial furflilment of the requirements for the degree of Doctor of Philosophy.

January 50,1960

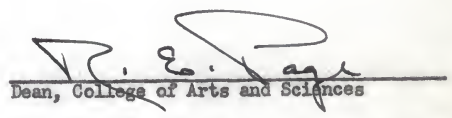

Dean, Gractuate School

\section{SUPERVISORY COAITTES:}
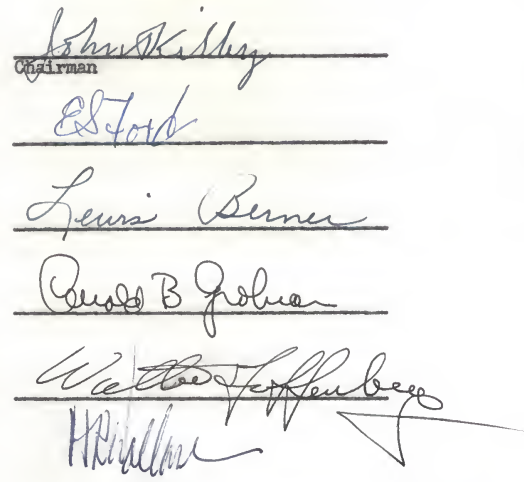